\title{
EXPERIMENTS ON THE STEAM-JACKETING AND COMPOUNDING OF LOCOMOTIVES IN RUSSIA.
}

By Mr. ALEXANDER BORODIN, ENginger-dx-ChIef, Russian South-Wfatern RaIlways, KiefF.

In consequence of the satisfactory results obtained by M. A. Mallet in applying the Compound system to the Locomotives of the Bayonne and Biarritz Railway, the Russian South-Western Railways in 1880 altered a locomotive to the compound system in accordance with M. Mallet's plans. At the same time another locomotive was provided with steam-jacketed cylinders.

It accordingly became desirable to make comparative tests with these engines. The whole of the experiments and investigations hitherto made, on the work of locomotive engines as well as on their consumption of fuel and water, appeared to the author to be deficient in completeness and accuracy, and based on data not sufficiently scientific. Struck by Mr. G. A. Hirn's remarkable practical theory of the steam engine, and by his beautiful method of investigation as developed by Mr. Hallauer and other Alsatian experimenters, the author was led to adopt the same method for his own researches on locomotives. It was thus the idea was originated of erecting a locomotive testing shop, in which a great number of the comparative tests were carried out.

But as Hirn's method had so far been applied to condensing engines only, some modifications had to be introduced in order to adapt it to locomotives working without condensation. For this purpose, and in order to clear up some points of detail, the author went to Colmar in 1880 to consult Mr. Hirn; and he wishes to acknowledge how materially his investigations have been aided by the consideration, forethought, and advice of this illustrious engineer. 
Another part of the trials was carried out by means of experimental trains; and in these the method adopted for the calculation of the work done, as well as of the consumption of steam and fuel, is due entirely to Mr. L. Loevy, locomotive engineer of the Russian South-Western Railways, by whom the whole of the trials were carried out.

\section{PART I.-Tests made in the Locomotive Testing Shop.}

A great number of tests, having for their object the investigation of the work done by the steam in locomotives, were carried out in the testing shop, which had already been proposed by the author in 1881.*

The whole of the arrangements in this testing shop were temporary; and as the author was not in possession of a friction brake capable of taking up the whole power given out by a locomotive, it was necessary to work the engine so as to develop not more than about 90 horse-power, which was used for driving the machine tools in the Kieff workshops. On this account the tests bad to be carried out with high grades of expansion and comparatively low pressures. The arrangements were advantageous for carrying out the experiments with rapidity and ease, as well as for obtaining all the verifications desired, including calorimetric tests as a check on the results arrived at.

\section{Description of the Testing Shop.}

The arrangement of the temporary testing shed is shown in Plates 64 to 66 . The locomotive, detached from its tender, was placed outside the Kieff repairing shop, at right angles to the side $A$ of the building, Figs. 1 and 4, and the engine, as well as all the apparatus used, was protected from the weather by a shed. The driving wheels were raised slightly above the rails, Fig. 1, the coupled wheels were uncoupled, and the driving wheels wero

* Organ für die Fortschritte des Eisenbahnwesens, 1881, Hefte 4 \& 5. 
transformed into driving pulleys. By means of belting they worked pulleys on an intermediate shaft SS, which communicated the motion to the main driving shaft in the repairing shop. The diameters of the pulleys were so proportioned that the locomotive could make 92 to 102 revolutions per minute, corresponding with speeds of $17 \frac{1}{2}$ to $19 \frac{1}{4}$ miles per hour. As the exhaust steam was condensed in a tank, and therefore conld not be utilised for augmenting the draught, it was necessary to lengthen the chimney of the locomotive in order to obtain sufficient draught. During the whole time of each test, which lasted from $1 \frac{1}{2}$ to $3 \frac{1}{2}$ hours, the locomotive worked at the same degree of expansion, with the regulator open to the same extent, and as far as possible at the same speed and with the same boiler pressure. The power given off by the engine was kept constant, and was equal to the minimum power necessary to drive the tools in the workshop; any additional power required, was provided by the shop engine. The slight irregularities which occurred during the tests, through increase of pressure or of speed, were allowed for as will be described.

The locomotive was provided with the following appliances for making observations :-

(1) A double pressure-gange, which had been verified with an open mercury column;

(2) A revolution-counter C, Fig. 1, Plate 64, recording the number of revolutions of the engine;

(3) A pressure-gango G for showing the pressure in the steamjackets ;

(4) Indicators I I on each cylinder, whereby diagrams could be taken from each end.

The water-gauge on the boiler was provided with internal baffle-plates, as shown in Figs. 9 and 10, Plate 67, so as to prevent oscillations in the glass tube.

In order to collect the exhaust steam from the cylinders, so that its weight might be determined as well as the number of thermal units it contained, as a check upon the consumption of water and the degree of moisture in the steam on leaving the boiler, the following arrangement was adopted. On a raised 
stage was placed a tank $T$, fitted with diaphragms, Figs. 3 and 5 , Plates 65 and 67 , and provided with an adjustable overflow $\mathbf{M}$, which served to regulate the level of the water brought into the tank $T$ ky the supply pipes $\mathrm{BB}$, and to discharge the surplus water into the side pocket $K$, and thence into the pipe $D$. The lower part of the tank was provided with an orifico $F$ in a thin plate, Fig. 5 , shown also to a larger scale in Fig. 6. The cold water continuously running into the tank $T$ flowed away freely through the orifice $F$ under an almost constant head above the centre of the orifice, which was easily maintained by means of the adjustable overflow $M$, supplemented by the cocks regulating the supply through the pipes BB. Besides this however, the head above the orifice was further measured by means of a glass water-gauge (Figs. 2 and 3) provided with a scale. The water flowing steadily out of the tank $T$ into a trough $R$ passed thence through an opening in the bottom of the trough, into the bent-up pipe $\mathrm{X}$, and thence into a larger pipe $\mathrm{Y}$, similarly bent, across which, as shown in Fig. 5, was a grating covered with a layer of coke; after passing through the coke and the grating, the water fell in a shower of rain through a pipe of large diameter, into a large tub $\mathrm{V}$, meeting on its way the exhaust steam from the cylinders, which was brought by the pipe $\mathrm{E}$ (Figs. 2 and 4 ) into the jacket $J$, and thence entered through numerous openings into the large rain-pipe. The exhaust steam, being thus brought into contact with the shower of rain, was partially condensed, and the mixture of water and steam fell into the tub $V$, where it mixed with the water in the tub, the level of which was constantly maintained high enough to keep the bottom of the rain-pipe always sealed, so as to prevent escape of uncondensed steam.

The lower part of the tub $V$ was provided with an orifice $H$ in a thin plate, Figs. 2 and 5, Plates 64 and 67, exactly similar to the orifice $\mathrm{F}$ in the tank $\mathrm{T}$, through which flowed away the warm water resulting from the mixture of cold water and condensed steam. The tub $\mathrm{V}$ was also provided with internal diaphragms, as shown in Fig. 5, for steadying the flow of the water, so that the waterlevel might easily be read off by means of a glass water-gauge, Fig. 2. 
The tank $\mathrm{T}$ and tub $\mathrm{V}$ were provided with thermometers, placed near the orifices $\mathrm{F}$ and $\mathrm{H}$. Although these two orifices were made with the same drill of $1 \frac{1}{2}$ inch diameter, the quantity of water flowing through them was not exactly equal, the difference amounting to about $\frac{1}{2}$ per cent.

The purpose of the arrangement above described is self-ovident. The quantity of cold water flowing out of the upper tank $T$ can be accurately determined, as the head is known, as well as the conditions of discharge through the orifice $\mathrm{F}$; the discharge of water from the lower tub V can be similarly determined. Consequently the difference between the two discharges from the upper and the lower vessel represents (after making some necessary corrections) the quantity of steam condensed, which can be used as a check on the consumption of feed-water that has been measured directly. The difference of temperature between the upper and the lower vessel renders it possible to calculato the quantity of heat in the exhaust steam; whence can be determined the quantity of water carried over by the steam from the boiler.

In order to measure directly the quantity of feed-water used, a vessel $\mathrm{P}$ was provided, Fig. 3, Plate 65 , which had been previously gauged, and which was fitted with a glass water-gauge; from this vessel the feed was taken through the pipe $\mathrm{N}$ by means of an injector, and the overflow from the injector was collected and measured in a wrought-iron tank W, Fig. 3. The vessel $P$ was refilled when necessary from the overflow of the tank $T$ by means of the pipe $D$, Fig. 2, an intermediate receiver $\mathrm{L}$, and a cock.

\section{Mode of conducting the Tests.}

The duration of each test varied from $1 \frac{1}{2}$ to $3 \frac{1}{2}$ hours. Throughout the whole duration of the test the pressure-gauge readings were noted every minute; the number of revolutions was counted every five minutes at the same time that the indicator diagrams were taken; this was independent of the readings noted from the counter. The water-levels in the upper and lower tanks $\mathrm{T}$ and $V$, as well as the thermometer readings in the latter, were noted every minute, the thermometer readings in the upper tank $T$ being 
taken every ten minutes only, because the temperature of the cold water was nearly constant during the whole of each experiment. The water-level in the boiler, as well as the reading of the counter, was taken at the commencement and at the end of each experiment. Finally, the wood used as fuel was weighed, although this information had no direct bearing on these tests, their only object being an analysis of the work done by the steam engine.

The observations thus made, after having undergone all the necessary corrections, furnished the following data for each test:-

(1) The total consumption of moist steam, ascertained by direct. ganging of the feed-water.

(2) The consumption of moist steam per revolution of the engine, obtained by dividing the total consumption by the total number of revolutions.

(3) The mean number of revolutions per minute for the whole duration of the experiment.

(4) The mean boiler-pressure, and the mean temperatures of the cold condensing water in the tank $T$, and of the warm water flowing away from the tub V.

(5) The mean head of water above the centre of the outlet orifice in the tank $T$ and in the tub $V$.

(6) The mean forward pressures and back pressures in the cylinders during the whole experiment, and separately for the front and back end of each cylinder.

(7) The mean indicated power developed during the whole of the experiment.

(8) The consumption of moist steam per indicated horse-power per hour. When the steam-jackets were at work, the steam consumption was measured both inclusively and exclusively of the water condensed in the jackets.

The consumption of steam per hour was also calculated per absolute horse-power on the supposition of the piston working against a perfect vacuum.

(9) The consumption of steam for heating the jackets; for this purpose the jackets were fitted with the self-acting steam-trap shown in Fig. 7, Plate 67, for discharging the condensed water, which was then weighed. 
Verification of the quantity of Water carried over by the steam.

The following symbols are adopted for this calculation :-

$Q$ the weight in kilograms of the water discharged from the upper

into the lower tank during tho whole experiment.

$M$ the total consumption in kilograms of moist steam by the cylinders during the same space of time.

$m$ the weight in kilograms of the water condensed in the jackets.

$t_{0}$ the mean temperature centigrade during the whole experiment of the cold water issuing from the tank $\mathbf{T}$.

$t_{1}$ the mean temperature centigrade of the warm water in the tub $V$. $t_{2}$ the mean temperature centigrade of the steam in the boiler.

$q_{0} q_{1} q_{2}$ the number of calories contained in one kilogram of water at the temperatures $t_{0} t_{1} t_{2}$.

$q_{3} q_{4}$ do. at the temperatures of the water in the lower tub $\mathrm{V}$ at the beginning and at the end of the experiment.

$x$ the mean quantity of dry steam contained in one kilogram of moist steam furnished by the boiler.

$T$ the total indicated power developed during the experiment, in kilogrammetres.

$R_{e}$ the number of calories lost during the experiment by external cooling.

$A_{1} A_{2}$ the weight in kilograms of the water contained in the tub $\mathrm{V}$ at the beginning and at the end of the experiment.

From the principles of the mechanical theory of heat, and taking 424 kilogrammetres as the mechanical equivalent of one (French) thermal unit, the following equation is arrived at when the jackets are not at work and when the external cooling $R_{e}$ is neglected:-

$$
\begin{gathered}
\left\{Q+M+\left(A_{1}-A_{2}\right)\right\} q_{1}+A_{2} q_{4}+\frac{T}{424}= \\
=M x\left(606 \cdot 5+0 \cdot 305 t_{2}\right)+M(1-x) q_{2}+Q q_{0}+A_{1} q_{3} ;
\end{gathered}
$$

whence

$x=\frac{Q\left(q_{1}-q_{0}\right)+M\left(q_{1}-q_{2}\right)+\frac{T}{424}+A_{1}\left(q_{1}-q_{3}\right)+A_{2}\left(q_{4}-q_{1}\right)}{M\left(606 \cdot 5+0 \cdot 305 t_{2}-q_{2}\right)} \ldots$.

and for the whole test the mean percentage of water carried over by the steam from the boiler will be $100(1-x)$. As the whole of the 
values in the second half of this equation are known from the experiments, the equation serves to determine the percentage of water carried over in each test.

When the jackets are at work, the steam condeused gives up one part of its heat $m\left(606 \cdot 5+0 \cdot 305 t_{2}-q_{2}\right)$ to the steam working in the cylinders, and the other part $R_{e}$ to the outside atmosphere, so that it is necessary to add to the numerator in the second half of equation (1)

$$
\left\{m\left(606 \cdot 5+0 \cdot 305 t_{2}-g_{2}\right)-R_{e}\right\}
$$

prefixing the negative sign (-).

In all these experiments that were made with an ordinary locomotive, the value $R_{e}$ was taken-in accordance with the results obtained by Hirn and Peclet as to the external cooling of cylinders and steam pipes-at 0.5 calorie ( $=1.98$ British thermal unit) for each cylinder and each revolution: which was so small that it was not deemed necessary to malie direct experiments on the external cooling of the jackets employed.

As almost all the tests were carried out under conditions more or less similar - that is to say, with only slight differences in pressure, speed, and consumption of steam-the quantity of water carried over by the steam should be approximately the same in all the experiments. Therefore the comparison of the values obtained for $x$ or $100(1-x)$ gave an idea of the degree of accuracy with which the experiments had been made and the calculations worked out. Furthermore, whenever the proportion of water carried over in any one experiment differed much from the mean values, this led to the suspicion and often to the detection of exrors, whether of observation or of calculation.

\section{Verification of the Consumption of Moist Steam.}

The methods of gauging the water flowing from the tank above and from the tub below, as well as of measuring the consumption of moist steam by the cylinders, have been already described. As the whole of this steam (with the exception of accidental leakages) passed into the lower tub along with the cold water from the upper 
tank, the weight of the water flowing out from the lower tub should, after allowing for the difference of water-level at tho beginning and end of the test, be equal to the weight of the water flowing from the upper tank together with the weight of the steam that has passed through the cylinders. The difference between these two values will indicate the degree of aceuracy with which the quantities of water flowing from these two vessels, and also the quantity of the feedwater, have been measured; or, what is the same thing, the difference between the quantities of water flowing out of the upper and lower vessels will give the consumption of steam in the cylinders, which was directly gauged as feed-water. This means of verification rendered it possible to correct some errors that may always occur, and to detect inaccuracies in some of the tests.

\section{Results obtained from Tests made in 1882 with an Ordinary locomotive A 22 steam-jacketed.}

This series of tests was made with a passenger engine, built by Cail, having four wheels coupled, and outside cylinders provided with steam-jackets, into which steam was supplied direct from the boiler through special pipes; the condensed water escaped from the jackets through the automatic steam-trap shown in Fig. 7, Plate 67. The steam could at pleasure be shut off from the jackets, so as to throw them out of action. Throughout the whole of these tests one cylinder only was working, the other being disconnected from the driving axle.

The following were the leading dimensions of the engine:-

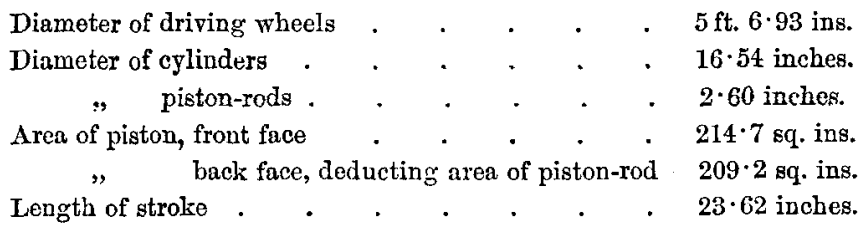

The clearances were determined by filling them with water when the piston was at the ends of its stroke; the front clearance was $7 \cdot 3$ per cent. and the back 8 per cent. of the volume described by the 
stroke of the piston. The slide-valves had 0.98 inch lap outside, and 0.04 inch inside; and were worked by Stephenson link-motion. With the reversing lever in the first and second notches the setting of the slide-valve was also varied in different tests, so as to givo altogether seven different distributions of sterm, of which some of the details are furnished in Table 1 on the opposite page.

As already explained, all the trials had to be made while the engine was developing no more than only 90 horse-power. Consequently, even though wcrking with ouly one cylinder, the tests had to be made with the reversing lever in the second or first notch of the quadrant, so as to cut off the steam as early as 30 or even 20 per cent. of the stroke, and with low boiler-pressures of not more than from 45 to 78 lbs. per square inch above the atmosphere.

The results obtained from the thirty-five experiments that were made are given in Table 2, pages 308 to 311 . The figures relating to the tests in which the steam-jacket was working are there indicated in distinctive type; and the following explanations are necessary.

Column 20 shows the degree of accuracy with which the quantities of water flowing from the upper and lower vessels were determined. In tho majority of the experiments the differences did not exceed 0.2 and 0.3 per cent.; in five they reached 0.4 and 0.5 per cent.; and in five they amounted to 0.6 and 0.7 per cent. Part of these differences must be attributed to the gauging of the consumption of feed-water, in consequence of the difficulty of accurately determining the water-level in the boiler.

Column 21 shows the limits of the possible errors in the gauging of the water consumed. In twenty-one of the experiments these limits did not exceed 4 per cent.; in four they reached 5 and 7 per cent.; and in seven they sometimes amounted to 10 and 11 per cent. These values have been arrived at on the supposition that the quantities of water flowing out of the upper and lower vessels were accurately measured; whatever errors may possibly have occurred in these measurements, the consequent errors in the estimation of the quantity of feed-water are evidently less. 
TABLE 1.-Details of seven different Steam Distributions.

\begin{tabular}{|c|c|c|c|c|c|c|c|c|}
\hline 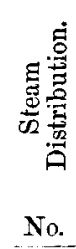 & 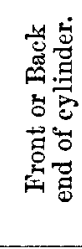 & $\begin{array}{c}\text { Linear. } \\
\text { Inch. }\end{array}$ & $\left\{\begin{array}{c}\text { Per cent. } \\
\text { of cyl. } \\
\text { area. }\end{array}\right.$ & $\begin{array}{l}\text { Linear. } \\
\text { Inch. }\end{array}$ & $\begin{array}{l}\text { mum } \\
\text { ing of } \\
\text { Ports. } \\
\text { Per cent. } \\
\text { of cyl. } \\
\text { areu. }\end{array}$ & $\left\{\begin{array}{c}\text { Cut- } \\
\text { off. } \\
\text { Per cent. }\end{array}\right.$ & 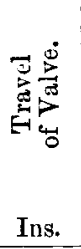 & Tests \\
\hline I. & $\begin{array}{l}\text { front } \\
\text { back }\end{array}$ & $\begin{array}{l}0.31 \\
0.12\end{array}$ & $\begin{array}{l}\text { Reversin } \\
\begin{array}{|c}1.78 \\
0.67\end{array}\end{array}$ & $\begin{array}{c}0.38 \\
0.19\end{array}$ & $\begin{array}{l}\text { second no } \\
2 \cdot 17 \\
1.06\end{array}$ & $\begin{array}{l}30 \cdot 0 \\
28 \cdot 5\end{array}$ & $2 \cdot 40$ & $\begin{array}{c}1 \\
\text { to } \\
4\end{array}$ \\
\hline II. & $\begin{array}{l}\text { front } \\
\text { back }\end{array}$ & $\begin{array}{l}0 \cdot 18 \\
0 \cdot 13\end{array}$ & $\begin{array}{l}1 \cdot 04 \\
0 \cdot 73\end{array}$ & $\begin{array}{l}0.25 \\
0.25\end{array}$ & $\begin{array}{l}1 \cdot 45 \\
1 \cdot 42\end{array}$ & $\begin{array}{l}25 \cdot 3 \\
34 \cdot 4\end{array}$ & $2 \cdot 40$ & $\begin{array}{l}5 \\
\text { to } \\
12\end{array}$ \\
\hline III. & $\begin{array}{l}\text { front } \\
\text { back }\end{array}$ & $\begin{array}{l}0 \cdot 15 \\
0 \cdot 15\end{array}$ & $\begin{array}{l}0 \cdot 84 \\
0 \cdot 84\end{array}$ & $\begin{array}{l}0.24 \\
0.31\end{array}$ & $\begin{array}{l}1 \cdot 3 t \\
1 \cdot 78\end{array}$ & $\begin{array}{l}23 \cdot 7 \\
36 \cdot 7\end{array}$ & $2 \cdot 40$ & $\begin{array}{c}13 \\
\text { and } \\
14\end{array}$ \\
\hline IV. & $\begin{array}{l}\text { front } \\
\text { back }\end{array}$ & $\begin{array}{l}0 \cdot 22 \\
0 \cdot 12\end{array}$ & $\begin{array}{l}1 \cdot 23 \\
0 \cdot 67\end{array}$ & $\begin{array}{l}0 \cdot 32 \\
0 \cdot 30\end{array}$ & $\begin{array}{l}1 \cdot 81 \\
1 \cdot 62\end{array}$ & $\begin{array}{l}26 \cdot 9 \\
32 \cdot 7\end{array}$ & $2 \cdot 42$ & $\begin{array}{c}15 \\
\text { and } \\
16\end{array}$ \\
\hline V. & $\begin{array}{l}\text { front } \\
\text { back }\end{array}$ & $\begin{array}{l}0.29 \\
0.04\end{array}$ & $\begin{array}{l}1 \cdot 65 \\
0 \cdot 22\end{array}$ & $\begin{array}{l}0 \cdot 38 \\
0 \cdot 24\end{array}$ & $\begin{array}{l}2 \cdot 17 \\
1 \cdot 34\end{array}$ & $\begin{array}{l}29 \cdot 4 \\
30 \cdot 0\end{array}$ & $2 \cdot 42$ & $\begin{array}{l}17 \\
\text { to } \\
28\end{array}$ \\
\hline & & & & & & & & \\
\hline VI. & $\begin{array}{l}\text { front } \\
\text { back }\end{array}$ & $\begin{array}{l}0.31 \\
0.03\end{array}$ & $\begin{array}{l}1.78 \\
0.17\end{array}$ & $\begin{array}{l}0.33 \\
0.08\end{array}$ & $\begin{array}{l}1 \cdot 90 \\
0.45\end{array}$ & $\begin{array}{l}22 \cdot 0 \\
17 \cdot 2\end{array}$ & $2 \cdot 36$ & $\begin{array}{l}29 \\
\text { to } \\
31\end{array}$ \\
\hline VII. & $\begin{array}{l}\text { front } \\
\text { back }\end{array}$ & $\begin{array}{l}0.27 \\
0.09\end{array}$ & $\begin{array}{l}1.54 \\
0.53\end{array}$ & $\begin{array}{l}0 \cdot 30 \\
0 \cdot 14\end{array}$ & $\begin{array}{l}1 \cdot 67 \\
0.78\end{array}$ & $\begin{array}{l}19 \cdot 5 \\
19 \cdot 7\end{array}$ & $2 \cdot 36$ & $\begin{array}{l}32 \\
\text { to } \\
35\end{array}$ \\
\hline
\end{tabular}


TABLE 2 (continued to page 311)

Tests made in 1882 with an Ordinary Locomotive A 22 Steam-Jacketed.

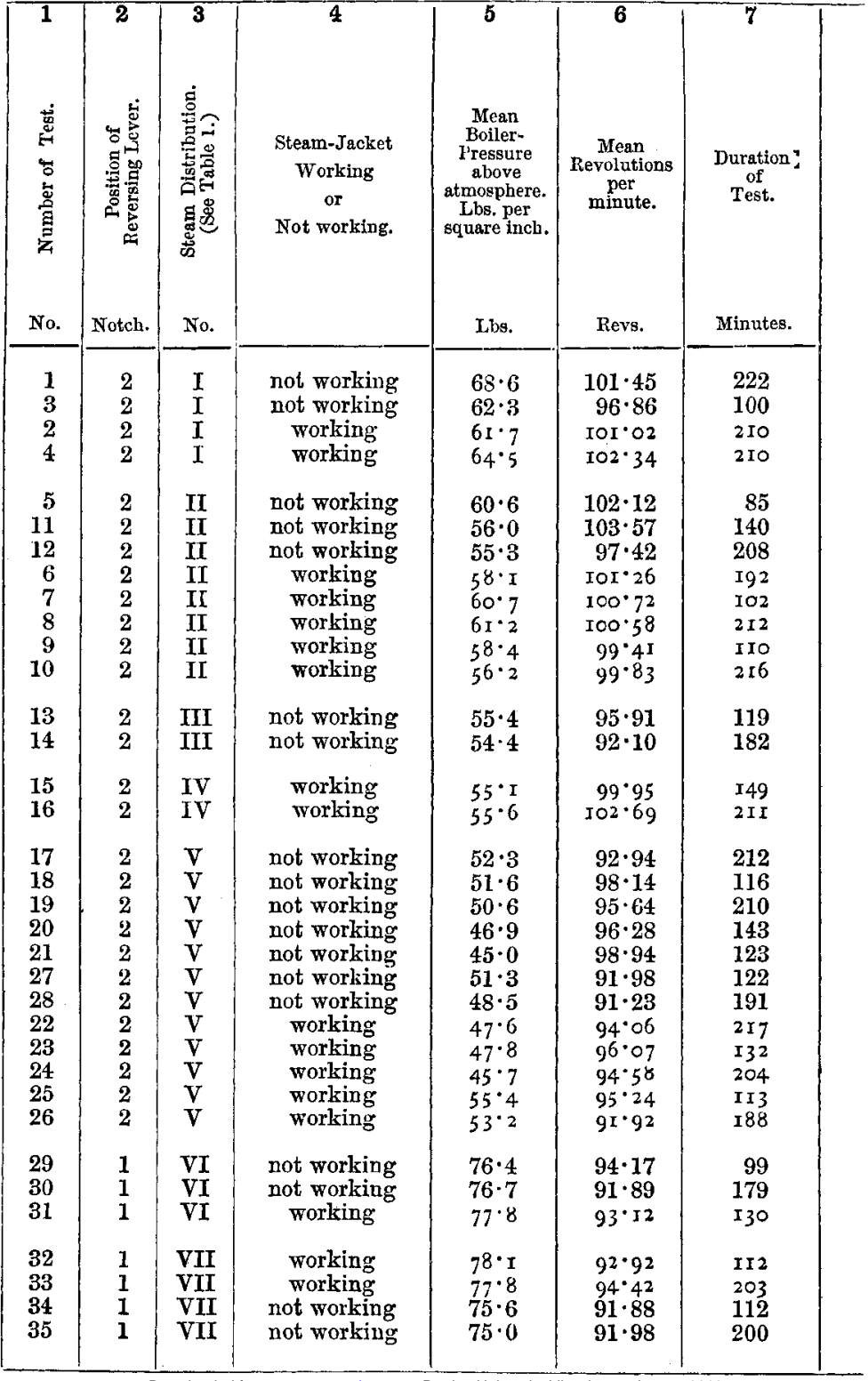


(continued on next page) TABLE 2.

Tests made in 1882 with an Ordinary Locomotive A 22 Steam-Jacketed.

\begin{tabular}{|c|c|c|c|c|c|c|c|}
\hline \multirow{3}{*}{ 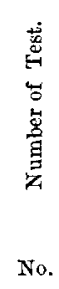 } & \multirow{2}{*}{\multicolumn{3}{|c|}{$\begin{array}{l}8 \\
9\end{array}$}} & \multicolumn{4}{|c|}{$\begin{array}{l}\text { Mean Cylinder Pressures } \\
\text { above atmosphere, } \\
\text { measured from indicator diagrams. } \\
\text { Lbs. per square inch. }\end{array}$} \\
\hline & & & & Forwar & Pressure. & Back $\mathrm{P}$ & ressure. \\
\hline & $\begin{array}{c}\text { In Cylinder. } \\
\quad \mathrm{Lb} \text {. }\end{array}$ & $\begin{array}{c}\text { In Jacket. } \\
\text { Lb. }\end{array}$ & $\begin{array}{l}\text { Total. } \\
\text { Lb. }\end{array}$ & $\begin{array}{l}\text { Front } \\
\text { end. } \\
\text { Lbs. }\end{array}$ & $\begin{array}{l}\text { Back } \\
\text { end. } \\
\text { I.bs. }\end{array}$ & $\begin{array}{l}\text { Front } \\
\text { end. } \\
\text { Lbs. }\end{array}$ & $\begin{array}{l}\text { Back } \\
\text { end. } \\
\text { Lbs. }\end{array}$ \\
\hline $\begin{array}{l}1 \\
3 \\
2 \\
4\end{array}$ & $\begin{array}{l}0 \cdot 32688 \\
0 \cdot 29839 \\
0 \cdot 29098 \\
0 \cdot 27862\end{array}$ & $\begin{array}{c}\cdots \\
\cdots \\
0.00675 \\
0.00666\end{array}$ & $\begin{array}{l}0.32688 \\
0.29839 \\
0.29773 \\
0.28527\end{array}$ & $\begin{array}{l}33 \cdot 63 \\
32 \cdot 58 \\
33 \cdot 53 \\
35 \cdot 52\end{array}$ & $\begin{array}{l}26 \cdot 05 \\
25 \cdot 34 \\
24 \cdot 70 \\
27 \cdot 50\end{array}$ & $\begin{array}{l}6 \cdot 67 \\
6 \cdot 03 \\
6 \cdot 60 \\
6 \cdot 41\end{array}$ & $\begin{array}{l}8 \cdot 86 \\
8 \cdot 57 \\
9 \cdot 28 \\
8 \cdot 54\end{array}$ \\
\hline $\begin{array}{r}5 \\
11 \\
12 \\
6 \\
7 \\
5 \\
9 \\
10\end{array}$ & $\begin{array}{l}0.29996 \\
0.27170 \\
0.27318 \\
0.25375 \\
0.29504 \\
0.27077 \\
0.26975 \\
0.24619\end{array}$ & $\begin{array}{c}\cdots \\
\cdots \\
\cdots \\
0.000672 \\
0.00708 \\
0.00675 \\
0.00686 \\
0.00756\end{array}$ & $\begin{array}{l}0.29996 \\
0.27170 \\
0.27318 \\
0.26047 \\
0.30212 \\
0.27752 \\
0.27662 \\
0.25375\end{array}$ & $\begin{array}{l}26 \cdot 18 \\
25 \cdot 70 \\
25 \cdot 15 \\
26 \cdot 22 \\
27 \cdot 39 \\
27 \cdot 34 \\
25 \cdot 97 \\
25 \cdot 23\end{array}$ & $\begin{array}{l}33 \cdot 90 \\
31 \cdot 90 \\
31 \cdot 52 \\
33 \cdot 12 \\
34 \cdot 05 \\
34 \cdot 99 \\
33 \cdot 38 \\
32 \cdot 19\end{array}$ & $\begin{array}{l}8 \cdot 64 \\
8 \cdot 17 \\
8 \cdot 31 \\
8 \cdot 51 \\
8 \cdot 25 \\
8 \cdot 61 \\
8 \cdot 32 \\
8 \cdot 21\end{array}$ & $\begin{array}{l}7 \cdot 28 \\
8 \cdot 31 \\
7 \cdot 86 \\
7 \cdot 60 \\
7 \cdot 41 \\
7 \cdot 86 \\
7 \cdot 89 \\
7 \cdot 84\end{array}$ \\
\hline $\begin{array}{l}13 \\
14\end{array}$ & $\begin{array}{l}0 \cdot 26541 \\
0.27081\end{array}$ & $\begin{array}{l}\ldots \\
\ldots\end{array}$ & $\begin{array}{l}0 \cdot 26541 \\
0 \cdot 27081\end{array}$ & $\begin{array}{l}21 \cdot 18 \\
22 \cdot 62\end{array}$ & $\begin{array}{l}30 \cdot 41 \\
30 \cdot 52\end{array}$ & $\begin{array}{l}8 \cdot 50 \\
7 \cdot 81\end{array}$ & $\begin{array}{l}7 \cdot 09 \\
7 \cdot 07\end{array}$ \\
\hline $\begin{array}{l}15 \\
16\end{array}$ & $\begin{array}{l}0.22044 \\
0.21634\end{array}$ & $\begin{array}{l}0.00622 \\
0.00608\end{array}$ & $\begin{array}{l}0.22666 \\
0.22242\end{array}$ & $\begin{array}{l}22 \cdot 55 \\
23 \cdot 40\end{array}$ & $\begin{array}{l}30.05 \\
30.86\end{array}$ & $\begin{array}{l}8 \cdot 63 \\
8 \cdot 97\end{array}$ & $\begin{array}{l}7 \cdot 36 \\
7 \cdot 64\end{array}$ \\
\hline $\begin{array}{l}17 \\
18 \\
19 \\
20 \\
21 \\
27 \\
28 \\
22 \\
23 \\
24 \\
25 \\
26\end{array}$ & $\begin{array}{l}0 \cdot 25443 \\
0 \cdot 25253 \\
0 \cdot 26179 \\
0 \cdot 22418 \\
0 \cdot 20560 \\
0 \cdot 23969 \\
0 \cdot 24862 \\
0 \cdot 18201 \\
0 \cdot 18812 \\
0 \cdot 17835 \\
0 \cdot 22842 \\
0 \cdot 22097\end{array}$ & $\begin{array}{c}\ldots \\
\ldots \\
\ldots \\
\ldots \\
\ldots \\
\cdots \\
0.00657 \\
0.00712 \\
0.00675 \\
0.00778 \\
0.00789\end{array}$ & $\begin{array}{c}0 \cdot 25443 \\
0 \cdot 25253 \\
0 \cdot 26179 \\
0 \cdot 22418 \\
0 \cdot 20560 \\
0 \cdot 23969 \\
0 \cdot 24862 \\
0 \cdot 18858 \\
0 \cdot 19524 \\
0 \cdot 18510 \\
0 \cdot 23620 \\
0 \cdot 22886\end{array}$ & $\begin{array}{l}24 \cdot 83 \\
23 \cdot 73 \\
23 \cdot 12 \\
22 \cdot 40 \\
20 \cdot 36 \\
22 \cdot 74 \\
21 \cdot 02 \\
22 \cdot 61 \\
22 \cdot 29 \\
21 \cdot 36 \\
26 \cdot 17 \\
24 \cdot 90\end{array}$ & $\begin{array}{l}25 \cdot 75 \\
24 \cdot 78 \\
24 \cdot 11 \\
23 \cdot 09 \\
20 \cdot 59 \\
23 \cdot 93 \\
21 \cdot 99 \\
22 \cdot 92 \\
22 \cdot 67 \\
21 \cdot 68 \\
28 \cdot 37 \\
26 \cdot 28\end{array}$ & $\begin{array}{l}6 \cdot 89 \\
6 \cdot 14 \\
5 \cdot 87 \\
5 \cdot 76 \\
6 \cdot 22 \\
6 \cdot 64 \\
5 \cdot 69 \\
6 \cdot 97 \\
7 \cdot 00 \\
6 \cdot 63 \\
6 \cdot 51 \\
6 \cdot 64\end{array}$ & $\begin{array}{l}7 \cdot 31 \\
7 \cdot 00 \\
6 \cdot 34 \\
6 \cdot 88 \\
7 \cdot 28 \\
7 \cdot 36 \\
7 \cdot 03 \\
7 \cdot 69 \\
7 \cdot 67 \\
7 \cdot 54 \\
7 \cdot 23 \\
7 \cdot 45\end{array}$ \\
\hline $\begin{array}{l}29 \\
30 \\
31\end{array}$ & $\begin{array}{l}0.26414 \\
0.26299 \\
0.2462 \text { I }\end{array}$ & $\begin{array}{c}\ldots \\
0.00820\end{array}$ & $\begin{array}{l}0.26414 \\
0.26299 \\
0 \cdot 2544 \mathrm{I}\end{array}$ & $\begin{array}{l}29 \cdot 61 \\
29 \cdot 05 \\
3+02\end{array}$ & $\begin{array}{l}28 \cdot 24 \\
27 \cdot 84 \\
30 \cdot 63\end{array}$ & $\begin{array}{c}9 \cdot 19 \\
9 \cdot 23 \\
10 \cdot 00\end{array}$ & $\begin{array}{l}9 \cdot 06 \\
9 \cdot 10 \\
9 \cdot 95\end{array}$ \\
\hline $\begin{array}{l}32 \\
33 \\
34 \\
35\end{array}$ & $\begin{array}{l}0.23789 \\
0.23016 \\
0.26973 \\
0.27372\end{array}$ & $\begin{array}{c}0.00869 \\
0.00747 \\
\ldots \\
\ldots\end{array}$ & $\begin{array}{l}0.24658 \\
0.23763 \\
0.26973 \\
0.27372\end{array}$ & $\begin{array}{l}30 \cdot 09 \\
29 \cdot 61 \\
26 \cdot 90 \\
28 \cdot 12\end{array}$ & $\begin{array}{l}35 \cdot 47 \\
34 \cdot 85 \\
32 \cdot 22 \\
32 \cdot 93\end{array}$ & $\begin{array}{l}10 \cdot 17 \\
11 \cdot 35 \\
11 \cdot 33 \\
11 \cdot 07\end{array}$ & $\begin{array}{r}10.03 \\
9.97 \\
10.25 \\
9 \cdot 72\end{array}$ \\
\hline
\end{tabular}


TABLE 2 (continued from preceding page)

Tests made in 1882 with an Ordinary Locomotive A 22 Steam-Jacketed.

\begin{tabular}{|c|c|c|c|c|c|c|c|}
\hline 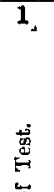 & 15 & $\begin{array}{c}16 \\
\\
\text { Consum } \\
\text { Moist } \\
\text { per hors } \\
\text { per } \mathrm{b}\end{array}$ & \begin{tabular}{l}
17 \\
\multicolumn{1}{c}{17} \\
stion of \\
Steam \\
se-power \\
hour.
\end{tabular} & 要㻤 & Wood & 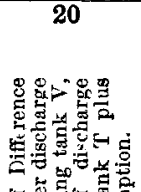 & 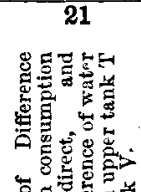 \\
\hline 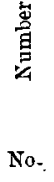 & 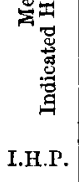 & $\begin{array}{c}\text { In } \\
\text { Cylinder } \\
\text { alone. } \\
\text { Lbs. }\end{array}$ & $\begin{array}{c}\text { In } \\
\text { Cyliniler } \\
\text { and } \\
\text { Jacket } \\
\text { togetber. } \\
\text { Lbs. }\end{array}$ & 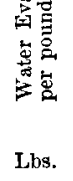 & $\begin{array}{l}\text { as } \\
\text { fuel. }\end{array}$ & 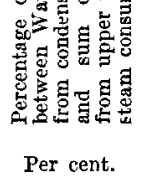 & 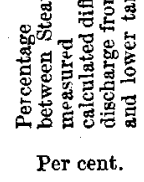 \\
\hline $\begin{array}{l}1 \\
3 \\
2 \\
4\end{array}$ & $\begin{array}{l}57 \cdot 5 \\
54 \cdot 0 \\
55 \cdot 0 \\
63 \cdot 3\end{array}$ & $\begin{array}{l}34 \cdot 55 \\
32 \cdot 14 \\
32 \cdot 03 \\
27 \cdot 05\end{array}$ & $\begin{array}{l}34 \cdot 55 \\
32 \cdot 14 \\
32 \cdot 78 \\
27 \cdot 69\end{array}$ & $\begin{array}{c}3 \cdot 54 \\
\ldots \\
3.59 \\
4.08\end{array}$ & $\begin{array}{l}\text { mixed } \\
\text { " } \\
\text { f̈r }\end{array}$ & $\begin{array}{c}\cdots \\
+\ddot{v} \cdot 1 \\
\ldots \\
\ldots\end{array}$ & $\begin{array}{c}\cdots \\
-1 \\
\cdots \\
\cdots\end{array}$ \\
\hline $\begin{array}{r}5 \\
11 \\
12 \\
6 \\
7 \\
8 \\
9 \\
10\end{array}$ & $\begin{array}{l}57 \cdot 7 \\
54 \cdot 5 \\
50 \cdot 5 \\
56 \cdot 5 \\
59 \cdot 0 \\
59 \cdot 0 \\
49 \cdot 9 \\
52.8\end{array}$ & $\begin{array}{l}31 \cdot 86 \\
30 \cdot 97 \\
31 \cdot 61 \\
27 \cdot 51 \\
30 \cdot 23 \\
27 \cdot 69 \\
29 \cdot 32 \\
27 \cdot 91\end{array}$ & $\begin{array}{l}31 \cdot 86 \\
30 \cdot 97 \\
31 \cdot 61 \\
28 \cdot 24 \\
30 \cdot 51 \\
28 \cdot 40 \\
30 \cdot 07 \\
28 \cdot 77\end{array}$ & $\begin{array}{l}3 \cdot 46 \\
3 \cdot 61 \\
3 \cdot 71 \\
3 \cdot 46 \\
4 \cdot 34 \\
3 \cdot 71 \\
3 \cdot 28 \\
3 \cdot 57\end{array}$ & $\begin{array}{l}\text { fir } \\
\text { oak } \\
\text { fir } \\
\text { "' } \\
" \\
"\end{array}$ & $\begin{aligned}- & 0.6 \\
+ & 0.1 \\
+ & 0.05 \\
& 0 \\
- & 0.4 \\
+ & 0.1 \\
- & 0.7 \\
+ & 0.2\end{aligned}$ & $\begin{array}{l}-8 \\
+\quad 2 \\
+1 \\
\\
-\quad 5 \\
+\quad 5 \\
+10 \\
+4\end{array}$ \\
\hline $\begin{array}{l}13 \\
14\end{array}$ & $\begin{array}{l}44 \cdot 1 \\
45 \cdot 1\end{array}$ & $\begin{array}{l}34 \cdot 61 \\
33 \cdot 20\end{array}$ & $\begin{array}{l}34 \cdot 61 \\
33 \cdot 20\end{array}$ & $\begin{array}{l}4 \cdot 08 \\
3 \cdot 43\end{array}$ & oak & $\begin{array}{l}-0.1 \\
-0.2\end{array}$ & $\begin{array}{l}-2 \\
+3\end{array}$ \\
\hline $\begin{array}{l}15 \\
16\end{array}$ & $\begin{array}{l}46 \cdot 8 \\
49 \cdot 4\end{array}$ & $\begin{array}{l}28 \cdot 26 \\
26 \cdot 96\end{array}$ & $\begin{array}{l}29 \cdot 06 \\
27 \cdot 7 I\end{array}$ & $\begin{array}{l}4.04 \\
3.90\end{array}$ & oak & $\begin{array}{l}+0 \cdot r \\
+0 \cdot r\end{array}$ & $\begin{array}{l}+2 \\
+2\end{array}$ \\
\hline $\begin{array}{l}17 \\
18 \\
19 \\
20 \\
21 \\
27 \\
28 \\
22 \\
23 \\
24 \\
25 \\
26\end{array}$ & $\begin{array}{l}43 \cdot 4 \\
44 \cdot 5 \\
43 \cdot 0 \\
40 \cdot 6 \\
34 \cdot 8 \\
38 \cdot 4 \\
35 \cdot 5 \\
37 \cdot 2 \\
37 \cdot 3 \\
35 \cdot 0 \\
49 \cdot 8 \\
43 \cdot 7\end{array}$ & $\begin{array}{l}32 \cdot 72 \\
33 \cdot 40 \\
34 \cdot 97 \\
31: 92 \\
35 \cdot 03 \\
34 \cdot 33 \\
38 \cdot 38 \\
27 \cdot 58 \\
29 \cdot 06 \\
28 \cdot 90 \\
26 \cdot 21 \\
27 \cdot 89\end{array}$ & $\begin{array}{l}32 \cdot 72 \\
33 \cdot 40 \\
34 \cdot 97 \\
31 \cdot 92 \\
35 \cdot 03 \\
34 \cdot 33 \\
38 \cdot 38 \\
28 \cdot 57 \\
30 \cdot 16 \\
29 \cdot 98 \\
27 \cdot 09 \\
28 \cdot 88\end{array}$ & $\begin{array}{l}3 \cdot 77 \\
3 \cdot 96 \\
4 \cdot 33 \\
2 \cdot 92 \\
3 \cdot 67 \\
4 \cdot 92 \\
4 \cdot 09 \\
3 \cdot 62 \\
4 \cdot 18 \\
3 \cdot 69 \\
5 \cdot 60 \\
4 \cdot 55\end{array}$ & $\begin{array}{c}\text { oak } \\
\text { alder } \\
\text { " } \\
\text { ", } \\
\text { mixed } \\
\text { alder } \\
\text { mixed } \\
\text { ", } \\
\text { ", }\end{array}$ & $\begin{array}{l}+0.3 \\
-0.4 \\
-0.6 \\
-0.5 \\
+0.2 \\
+0.3 \\
+0.6 \\
+0.6 \\
+0.1 \\
+0.1 \\
+0.1 \\
+0.1\end{array}$ & $\begin{array}{l}+4 \\
-6 \\
-8 \\
-9 \\
+4 \\
+5 \\
+9 \\
+11 \\
+1 \\
-3 \\
+2 \\
+2\end{array}$ \\
\hline $\begin{array}{l}29 \\
30 \\
31\end{array}$ & $\begin{array}{l}47 \cdot 8 \\
45 \cdot 4 \\
49 \cdot 8\end{array}$ & $\begin{array}{l}31 \cdot 20 \\
31 \cdot 90 \\
27 \cdot 62\end{array}$ & $\begin{array}{l}31 \cdot 20 \\
31 \cdot 90 \\
28 \cdot 53\end{array}$ & $\begin{array}{l}4 \cdot 33 \\
4 \cdot 89 \\
5 \cdot 17\end{array}$ & $\begin{array}{c}\text { mixed } \\
",\end{array}$ & $\begin{array}{rl} & 0 \\
-0 & 0 \\
0\end{array}$ & $\begin{array}{r}0 \\
-\quad 1 \\
0\end{array}$ \\
\hline $\begin{array}{l}32 \\
33 \\
34 \\
35\end{array}$ & $\begin{array}{l}54 \cdot 8 \\
52 \cdot 3 \\
44 \cdot 1 \\
47 \cdot 4\end{array}$ & $\begin{array}{l}24 \cdot 18 \\
25 \cdot 00 \\
33 \cdot 69 \\
31 \cdot 86\end{array}$ & $\begin{array}{l}25 \cdot 07 \\
25 \cdot 82 \\
33 \cdot 69 \\
31 \cdot 86\end{array}$ & $\begin{array}{l}4 \cdot 46 \\
4 \cdot 87 \\
4 \cdot 40 \\
4 \cdot 89\end{array}$ & $\begin{array}{c}\text { mixed } \\
\quad, \\
",\end{array}$ & $\begin{array}{l}+0.5 \\
+0.4 \\
+0.2 \\
+0.1\end{array}$ & $\begin{array}{l}+8 \\
+7 \\
+2 \\
+1\end{array}$ \\
\hline
\end{tabular}


(concluded from page 308) TABLE 2. Tests made in 1882 with an Ordinary Locomotive A 22 Steam-Jacketed.

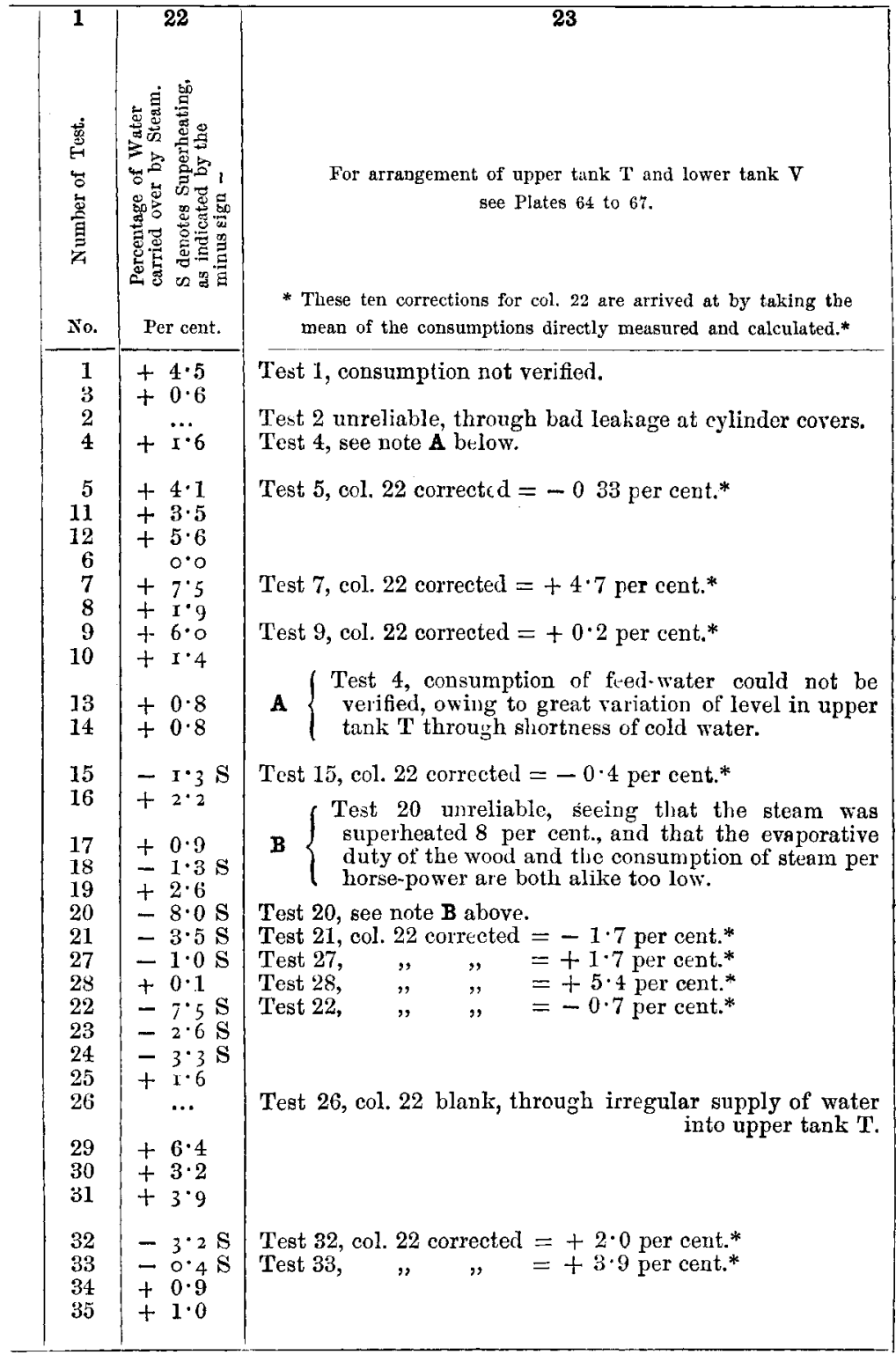


Column 22 shows the percentage of water carried over by the steam leaving the boiler and measured as previously described. At the same time this column gives an idea of the degree of accuracy with which all the observations and calculations were carried out. In the majority of the experiments, as here seen, the percentage of water carried over is small enough, not exceeding 4 per cent.; some experiments indicate a slight degree of superheating, not exceeding $3 \frac{1}{2}$ per cent. Only eight tests have given a higher degree of moisture or of superheating, amounting in two experiments to $7 \frac{1}{2}$ per cent. It must also be observed that in these last eight experiments columns 20 and 21 show less accuracy in the estimation of the consumption of feed-water, and of the quantities of water flowing out of the upper and lower vessels; whence it may be assumed that some error took place in the gauging of the water consumed. Taking the mean consumption between that directly gauged and that calculated from the difference of the water discharges from the upper and lower vessels, degrees of moisture are obtained in column 23 equal to those shown by the other experiments. Experiment No. 20 forms the only exception, and therefore is not to be relied on; the small consumption of stenm per horse-power, the low evaporative duty of the wood used, and the high degree of superheating, all throw doubt upon the accuracy of the results obtained in this test.

Considering the large number of factors in equation (1) page 303, and the large number of observations and of minute and complicated calculations necessary for determining the degree of moisture in the steam, the results obtained may be accepted as very favourable and as fully reliable; they prove the degree of accuracy of the method employed.

Columns 16 and 17 give for each experiment the consumption of moist steam per indicated horse-power per hour. The results of all the tests without exception indicate a lower consumption when the jacket was working, and even each individual experiment with the jacket at work shows a lower consumption than any of those in which the jacket was not at work; experiment No. 2 seems the only exception, but this test, as noted in column 23, cannot be fully relied on, owing to extensive leakage which occurred at the 
cylinder covers during the experiment. The utility of the steamjacket in the locomotive engine tested, working under the conditions under which these experiments were carried out, is therefore completely demonstrated.

The total consumption of steam in Ibs. per indicated horse-power per hour (Table 2, column 17) was as follows:-

Reversing lever in second notch. Cut-off about 30 per cent.

Steam Distribution No. I. (See Table 1.)

Without jacket.

$34 \cdot 55 \mathrm{lbs}$.

$32 \cdot 14$,

Mean $33 \cdot 34$ lbs.
With jacket.

$32 \cdot 78 \mathrm{lbs}$.

$27 \cdot 69$,

Mean $30 \cdot 24 \mathrm{lbs}$.

Steam Distribution No. II.

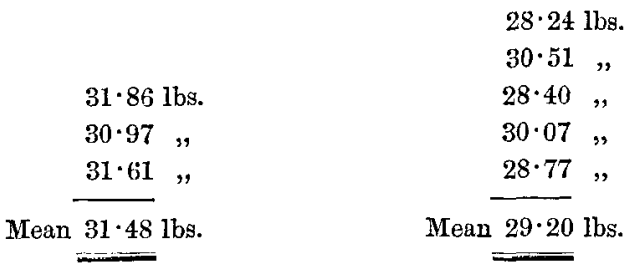

Steam Distribution No. III. Steam Distribution No. IV.

$34 \cdot 61 \mathrm{lbs}$. $29 \cdot 06 \mathrm{lbs}$.

$33 \cdot 20$, $27 \cdot 71$,

Mean 33.91 lbs.

Mean $28 \cdot 38 \mathrm{lbs}$.

Steam Distribution No. V.

$32 \cdot 72$ lbs.

$33 \cdot 40$,

$28 \cdot 57$ lbs.

$34 \cdot 97$,

$30 \cdot 16$,

$31 \cdot 92$,

$29 \cdot 98$,

$35 \cdot 03$,

$27 \cdot 09$,

$34 \cdot 33$,

$28 \cdot 88$,"

Mean $33 \cdot 73 \mathrm{lbs}$.

Mean $28 \cdot 94 \mathrm{lbs}$ 
Experiment No. 28 has not here been included under distribution No. $V$ without jacket, owing to an abnormal steam consumption of 38.38 lbs. per horse-power per hour; if this were included, the mean of the tests without jacket would be $34.39 \mathrm{lbs}$. instead of $33.73 \mathrm{lbs}$.

Reversing lever in first notch. Cut-off about 20 per cent.

$$
\text { Steam Distribution No. VI. }
$$

Without jacket.

$31 \cdot 20$ lbs.

$31 \cdot 90$,

Mean $31 \cdot 55$ Ibs.
With jacket.

$28 \cdot 53$ lbs.

Mean $28 \cdot 53 \mathrm{lbs}$.

Steam Distribution No. VII.

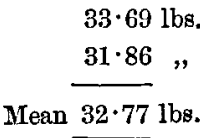

$25 \cdot 07 \mathrm{lbs}$. $25 \cdot 82$,

Mean $25 \cdot 44$ lbs.

In Table 3 are grouped together all the means of these results :-

TABLE 3. Steam Consumption with and without Steam-Jacket.

\begin{tabular}{|c|c|c|c|}
\hline \multirow{2}{*}{$\begin{array}{l}\text { Reversing } \\
\text { Lever, } \\
\text { and } \\
\text { Cut-off. }\end{array}$} & \multirow{2}{*}{$\begin{array}{c}\text { Steam } \\
\text { Distribution. } \\
\text { See Table } 1 .\end{array}$} & \multicolumn{2}{|c|}{$\begin{array}{l}\text { Consumption of Moist Steam } \\
\text { per horse-power per hour. }\end{array}$} \\
\hline & & $\begin{array}{l}\text { Without Jacket. } \\
\text { Lbs. }\end{array}$ & $\begin{array}{c}\text { With Jacket. } \\
\text { Lbs. }\end{array}$ \\
\hline \multirow[t]{2}{*}{$\begin{array}{l}\text { Second } \\
\text { noteh. } \\
\text { Cut-off } \\
\text { about } \\
\text { 30 per cent. }\end{array}$} & $\begin{array}{l}\text { No. I } \\
\text { No. II } \\
\text { No. III } \\
\text { No. IV } \\
\text { No. V }\end{array}$ & $\begin{array}{c}33 \cdot 34 \\
31 \cdot 48 \\
33 \cdot 91 \\
- \\
33 \cdot 73\end{array}$ & $\begin{array}{c}30 \cdot 24 \\
29 \cdot 20 \\
- \\
28 \cdot 38 \\
28 \cdot 94\end{array}$ \\
\hline & Average & $33 \cdot 11$ & $29 \cdot 19$ \\
\hline \multirow{2}{*}{$\begin{array}{c}\text { First } \\
\text { notch. } \\
\text { Out-off } \\
\text { about } \\
20 \text { per cent. }\end{array}$} & $\begin{array}{l}\text { No. VI } \\
\text { No. VII }\end{array}$ & $\begin{array}{l}31 \cdot 55 \\
32 \cdot 77\end{array}$ & $\begin{array}{l}28 \cdot 53 \\
25 \cdot 44\end{array}$ \\
\hline & Average & $32 \cdot 16$ & $26 \cdot 98$ \\
\hline
\end{tabular}


From the figures given in Table 3 the following conclusions may be drawn:-

(1) Whether the steam admission or the lead be made equal at both ends of the cylinder, neither method of regnlating the distribution has any perceptible influence on the consumption of steam.

(2) With the reversing lever in the second noteh, giving an admission during 30 per cent. of the stroke, the working of the jacket shows an average economy of 12 per cent. in consumption of steam; and with the lever in the first notch, giving an admission during 20 per cent. of the stroke, an average economy of 16 per cent. was obtained with the jacket working.

(3) The consumption of steam per horse-power per hour with 20 per cent. admission (first notch) is from 3 to $7 \frac{1}{2}$ per cent. lower than with an admission during 30 per cent. of the stroke (second notch). It must be observed however that the experiments when running in the first notch were made with a higher pressure of nearly 76 lbs. above the atmosphere; whilst during the experiments in the second notch the pressure was only about $54 \mathrm{lbs}$. The higher boiler-pressure may therefore have been the sole cause of this economy in steam consumption.

\section{Analysis of Indicator Diagrams.}

The utility of the steam-jacket having been proved, it is interesting to examine and explain the causes thereof. With this view will be selected experiments made under the same conditions of distribution, steam-pressure, and speed, with the jacket working and not working; and it will be endeavoured to ascertain the effect produced by the jacket on-

(1) The quantity of steam condensed in the cylinder during admission.

(2) The change in weight of dry steam contained in the cylinder during expansion.

For this purpose, two diagrams have been selected from amongst all those taken during each experiment, one from the front and the 
other from the back of the cylinder; and these two diagrams have been accepted as average diagrams for the whole experiment, that is to say, as together representing the mean work done by the steam during one revolution of the engine. In making this choice of diagrams, those were selected which were taken when the boiler pressure and the speed were about a mean for the whole trial, and which gave a mean cylinder pressure differing as little as possible from the calculated mean pressure for the-whole trial. From the large number of diagrams taken during each test, ranging from 16 to 44 diagrams from each end, it was always possible to find one which represented very nearly the conditions of the mean work of the steam during the whole trial.

The analysis of the average diagrams, selected in this way and shown in Plates 68 to 70 , was made in the following manner. According to the pressure indicated by the diagram, the weight of dry steam was calculated in each end of the cylinder, front and back, at the point of cut-off, at the end of the expansion, and at the end of the compression. From these data were deduced:- $(a)$ the change in weight of dry steam during expansion in each ond of the cylinder separately; and (b) the quantity of dry steam which during the admission was added to that already contained in the clearance spaces at both ends of the cylinder. A comparison of this last quantity with the consumption of moist steam per revolution of the engine (Table 2, column 10) gave the increase during admission in the weight of the condensed water contained in the cylinder. This increase represents the sum of the quantity of water carried over into the cylinder by the moist boiler-steam, and of the quantity of steam condensed in the cylinder during admission, owing to its contact with the cylinder walls which have been cooled down during the periods of expansion and exhaust.

Some explanations are necessary respecting the details of this calculation. In order to ascertain the weight of dry steam at the point of cut-off, the pressure was estimated, not at the point of the diagram corresponding exactly with the ond of the admission, as determined from the setting of the valve-motion when it was cold, 
but at a point corresponding with a position of the piston a little further from the commencement of the stroke, that is to say, at a point where the form of the diagram rendered it certain that the port had really closed. Similarly, in order to estimate the pressure at the end of the expansion, a point on the diagram was taken corresponding with a position of the piston when the exhaust had not yet commenced but was just about to commence. This course was adopted in order to avoid any such errors as would have occurred if points on the diagrams had been taken where the steam port had not completely closed or where the exhaust port had already opened. Similarly, in order to estimate the weight of dry steam remaining at the end of the compression, a point was taken in the compression curve of the diagram where the admission had not yet commenced but was very near commencing.

In this way comparative analyses were made of the average dingrams from nineteen experiments, taken at random; and the results of these analyses are grouped in Table 4 on page 318 , the average diagrams themselves being shown in Plates 68 to 70 .

The results in this Table 4 show that the effect of the steamjacket includes :-

(1) Chiefly a decrease in the quantity of steam condensed during admission; on the amount of this decrease depends the economy in the consumption of steam. This conclusion is confirmed by the whole of the nineteen experiments analysed, without exception, and may consequently be accepted as proved.

(2) A decrease in re-evaporation of water during expansion. With few exceptions this effect is observed in all the tests, particularly in those when running in the second notch with lower grades of expansion, and to a less extent in those when running in the first notch, that is, with higher grades of expansion.

(3) An increase of mean pressure in the cylinder. In the experiments made when working in the second notch with lower expansion this effect was less apparent, and sometimes not at all; whereas in all the experiments when working in the first notch with higher expansion it was manifest in a greater degree. 
TABLE 4. Results of analysis of Average Indicator Diagrams, Plates 68 to 70.

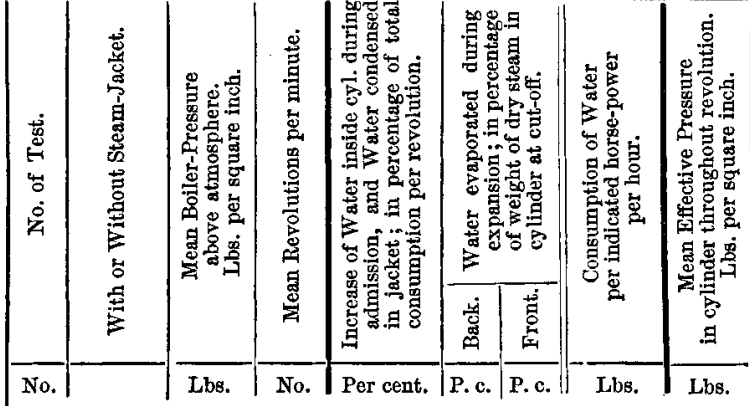

Reversing lever in second notch. Cut-off about 30 per cent.

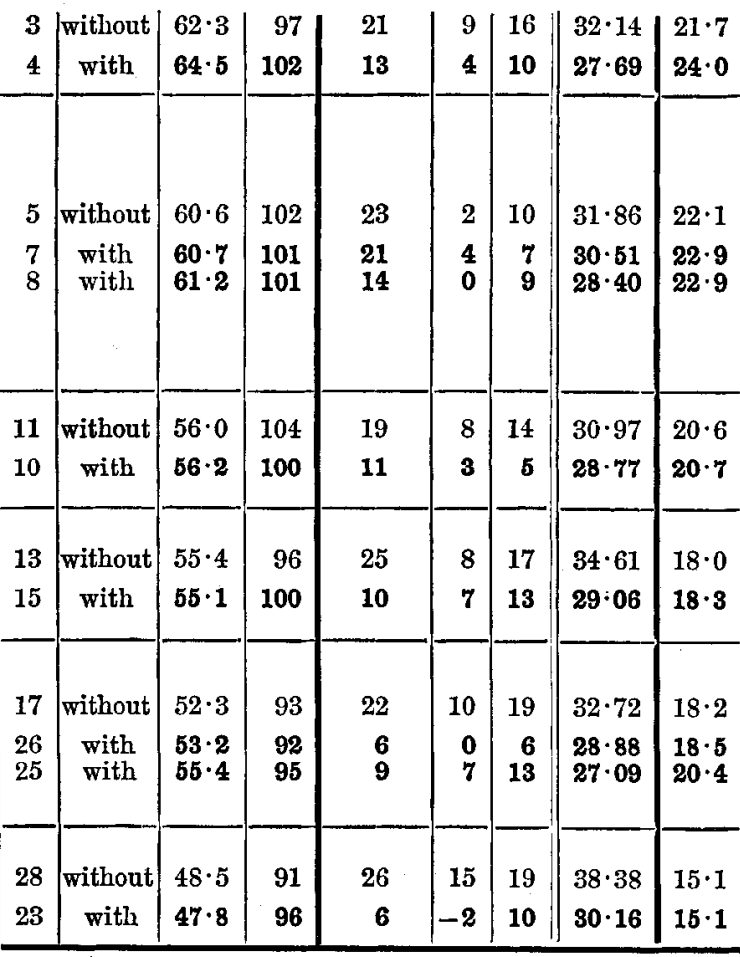

Reversing lever in first notch. Cut-off about 20 per cent.

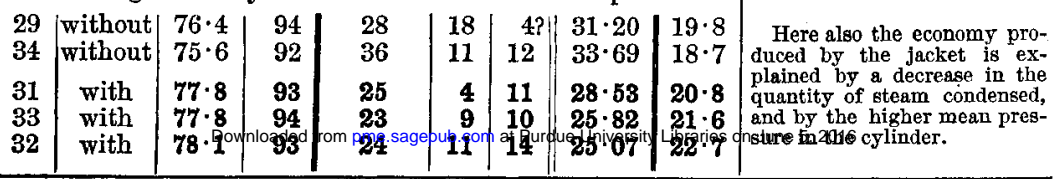

The jacket produced an economy of $14 \%$ in the consumption of steam, which is explained by the decrease of $8 \%$ in the quantity of steam condensed during admission and by the higher mean pressure in the cylinder.

The jacket gave in test No. 7 an economy of $4 \%$, which is explained by the decrease of $2 \%$ in the quantity of steam condensed during admission, and by the higher pressure in the cylinder. In test No. 8 the economy was $11 \%$, which is similarly explained by the decrease of $9 \%$ in the quantity of steam condensed, and by the higher mean pressure.

The jacket produced an economy of $7 \%$, arising from a decrease of $8 \%$ in the quantity of steam condensed.

The jacket produced an economy of $16 \%$ arising from a decrease of $15^{\circ} \%$ in the quantity of steam condensed.

In tests Nos. 26 and 25 the jacket produced an economy of 12 and $17 \%$ arising from a decrease of 16 and $13 \%$ in the quantity of steam condensed, and from the higher mean pressure in test No. 25 .

The jacket produced an economy of $21 \%$ arising from a decrease of $20 \%$ in the quantity of steam condensed. 


\section{Results obtained from Tests made in 1881} with an Ordinary locomotive A 21 not steam-jacketed.

These tests were carried out like the preceding ones on an ordinary locomotive of the same kind and of the same dimensions as the jacketed iocomotive A 22 already described, from which it differed only in not having its cylinder steam-jacketed.

The verifications of the consumption of feed-water and of the moisture of the steam, although made by the methods previously described, did not attain the necessary degree of accuracy, and failed to give satisfactory results. Since in other respects the tests were carried out in the manner already described, the results will here be given of the two tests only which were perfectly complete: namely one on the 16th of September 1881 when the reversing lever was in the second notch, and another on the 21st of July 1881 with the lever in the first notch.

TABLE 5. Test on 16 September 1881 ; reversing lever in second notch.

\begin{tabular}{|c|c|c|c|c|c|c|c|}
\hline \multirow{2}{*}{$\begin{array}{l}\text { Boiler } \\
\text { Pressure } \\
\text { above } \\
\text { atm. }\end{array}$} & \multirow{2}{*}{$\begin{array}{l}\text { Mean } \\
\text { Revs. } \\
\text { per } \\
\text { minute. }\end{array}$} & \multirow{2}{*}{$\begin{array}{l}\text { Duration } \\
\text { of } \\
\text { test. }\end{array}$} & \multicolumn{2}{|c|}{$\begin{array}{c}\text { Mean Effective } \\
\text { Pressure in cylinder. } \\
\text { Lbs. per square inch. }\end{array}$} & \multicolumn{2}{|c|}{$\begin{array}{l}\text { Consumption of } \\
\text { Moist Steam. }\end{array}$} & \multirow{2}{*}{$\begin{array}{c}\text { Mean } \\
\text { Indicated } \\
\text { Horse-power. }\end{array}$} \\
\hline & & & Back. & Front. & $\begin{array}{l}\text { per } \\
\text { revolution. }\end{array}$ & $\left\{\begin{array}{c}\text { per I.H.P. } \\
\text { per hour. }\end{array}\right.$ & \\
\hline $\begin{array}{l}\text { Labs. } \\
79 \cdot 8\end{array}$ & $\begin{array}{r}\text { Revs. } \\
105 \cdot 4\end{array}$ & $\begin{array}{c}\text { Minutes. } \\
75\end{array}$ & $\begin{array}{l}\text { Lbs. } \\
26 \cdot 75\end{array}$ & $\begin{array}{l}\text { Lbs. } \\
26 \cdot 46\end{array}$ & $\begin{array}{c}\text { Lb. } \\
0 \cdot 3283\end{array}$ & $\begin{array}{l}\text { Lbs. } \\
29 \cdot 85\end{array}$ & $\begin{array}{c}\text { I. H. P. } \\
69 \cdot 5\end{array}$ \\
\hline
\end{tabular}

Analysing the sample diagram of this test, shown in Fig. 22, Plate 71, we find :-

(a) During admission the quantity of water contained in the two ends of the cylinder was increased by $0.0619 \mathrm{lb}$, or 19 per cent. of the total consumption of steam per revolution.

(b) The quantity of water re-evaporated during expansion, compared with the quantity of dry steam present in the same end of the cylinder when the steam-port closed, was for the back end 22 per cent., and for the front 16 per cent. 
TABLE 6. Test on 21 July 1881; reversing lever in first notch.

\begin{tabular}{|c|c|c|c|c|c|c|c|}
\hline \multirow{2}{*}{$\begin{array}{c}\text { Boiler } \\
\text { Pressure } \\
\text { above } \\
\text { atm. }\end{array}$} & \multirow{2}{*}{$\begin{array}{c}\text { Mean } \\
\text { Revs. } \\
\text { per } \\
\text { minute. }\end{array}$} & \multirow{2}{*}{$\begin{array}{c}\text { Duration } \\
\text { of } \\
\text { test. }\end{array}$} & \multicolumn{2}{|c|}{$\begin{array}{l}\text { Mean Effective } \\
\text { Pressure in cylinder. } \\
\text { Lbs. per equare inch. }\end{array}$} & \multicolumn{2}{|c|}{$\begin{array}{l}\text { Consumption of } \\
\text { Moist Steam. }\end{array}$} & \multirow{2}{*}{$\begin{array}{c}\text { Mean } \\
\text { Indicated } \\
\text { Horse-power }\end{array}$} \\
\hline & & & Back. & Front. & $\begin{array}{l}\text { per } \\
\text { revolution. }\end{array}$ & $\begin{array}{l}\text { per I.H.P. } \\
\text { per hour. }\end{array}$ & \\
\hline $\begin{array}{l}\text { Lbs. } \\
91 \cdot 4\end{array}$ & $\begin{array}{l}\text { Revs. } \\
96 \cdot 9\end{array}$ & $\begin{array}{c}\text { Minutes. } \\
151\end{array}$ & $\begin{array}{l}\text { Lbs. } \\
24 \cdot 26\end{array}$ & $\begin{array}{l}\text { Lbs. } \\
26 \cdot 61\end{array}$ & $\begin{array}{c}\text { Lb. } \\
0 \cdot 3300\end{array}$ & $\begin{array}{l}\text { Lbs. } \\
30 \cdot 36\end{array}$ & $\begin{array}{c}\text { I. H. P. } \\
63 \cdot 3\end{array}$ \\
\hline
\end{tabular}

Analysing the sample diagram of this test, shown in Fig. 23, Plate 71, we find :-

(c) During admission the quantity of water contained in the cylinder was increased by $0.1314 \mathrm{lb}$, or 40 per cent. of the total consumption per revolution.

(d) The quantity of water re-evaporated during expansion was for the back end 20 per cent., and for the front 15 per cent. of the quantity of dry steam contained in the corresponding end of the cylinder when the steam-port closed.

Comparing these tests with those made without the jacket in 1882 on another engine of the same class, we find that the results obtained are generally the same, and that the conclusions drawn from the tests of 1882 are confirmed by the tests of 1881 . The quantity of steam condensed during admission was the same in these two sets of tests, and this quantity was always larger when working in the first notch with earlier cut-off than when working in the second with later. In the experiments of 1881 a larger quantity of water was re-evaporated during expansion; but it must also be borne in mind that the tests of 1881 had been carried out with higher boilerpressures of 80 and 91 lbs. above atm., as compared with 48 to 65 and 76 to $78 \mathrm{lbs}$. above atm. in those of 1882 , and consequently the conditions under which the steam was working were different. This higher boiler-pressure, as well as the more regular form of the diagrams, have had much to do with the decrease of consumption per horse-power in the unjacketed experiments of 1881. This decrease however is not so considerable as that obtained when the jacket was working in the experiments of 1882 ; therefore the benefit of the jacket is further confirmed by the unjacketed experiments of 1881 . 
It is equally interesting to note that the working in the first notch with greater expansion in the unjacketed trials of 1881 is not more economical than the working in the second notch with less expansion. This result agrees with the third conclusion drawn from the experiments of 1882 (see page 315 ); in reality the tests of 1882 gave a small economy of from 3 to $7 \frac{1}{2}$ per cent. when changing from the second notch with 30 per cent. admission to the first noteh with only 20 per cent. admission; but this result was believed to be caused by the increase of boiler-pressure from 54 up to $76 \mathrm{lbs}$. above atm.; and in the trials of 1881 this increase of pressure on changing from the second notch to the first was much less, namely from 80 up to 91 lbs. above atm. Moreover in the first notch no economy was obtained in consumption of steam, which is explained by a greater condensation during admission at the higher grades of expansion.

Turning from the indicated power to the net effective power, and bearing in mind the constant friction of the engine, it will be readily understood that the consumption of steam per effective horse-power will be larger when working in the first notch with earlier cut-off than in the second notch with later. Whence it may be concluded that cylinders of too large size are unfavourable to economy of steam.

\section{Results obtained from Tests made in 1881} with a Compound locomotive A 7 steam-jacketed.

These tests were made with a locomotive built by Cail, and compounded according to drawings supplied by M. A. Mallet. The diameter of the small cylinder remained the same, namely $16 \cdot 54$ inches, the large cylinder being increased to $23 \cdot 62$ inches, so that the cylinder areas were very nearly as 1 to 2 (accurately 1 to $2 \cdot 04$ ); the stroke was not altered, but the valive gear was so arranged that the cut-off could be varied for each cylinder independently of the other. The slide-valves had an external lap of 0.98 inch; the valve of the small cylinder had an internal lap of negative value, that is a clearance of 0.14 inch, so as to avoid too much compression.

Both of the cylinders, as well as their covers, were steam-jacketed, similarly to the ordinary engine A 22. 
The tests were made with both cylinders working, but with early cut-off and low boiler-pressure, corresponding with from 75 to 93 indicated horse-power. The mode of conducting the experiments, and their verification by means of the condensing apparatus, were the same as in the experiments of 1882 already described.

The results obtained when the jackets were not working are given in the following Table:-

\section{TABLE 7. Steam Consumption in Compound Engine when Steam-Jackets were not working.}

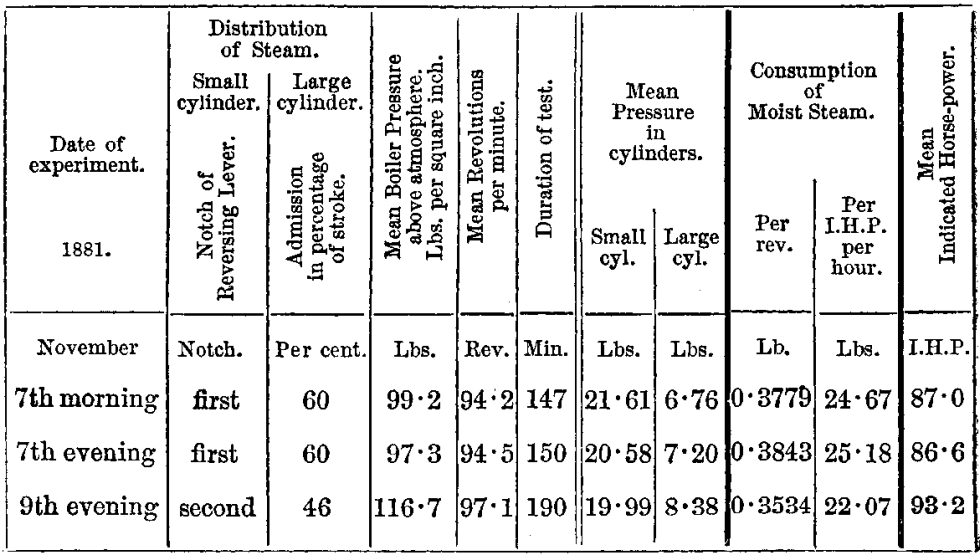

The experiments with the jackets working did not succeed, and gave very varying results in steam consumption, which was rather high compared with that when the jackets were not working. These unexpected results may be attributed either to the absence of circulation of steam by its being allowed to stagnate in the jackets, or to the imperfect draining of the condensed water, or to other defects of construction in the jackets.

The two tests made on the 7th of November were checked according to the calorimetric method already described. The degree of moisture of the steam was calculated for the first test at 6.7 per cent., and for the second test at 5.8 per cent.; part of the water in the steam must bo debited to the external cooling of the steam-pipes and of the starting-valve box, etc. As both the cylinders 
were at work during these tests of the compound engine, the cooling surface was greater than in the tests with the ordinary engine A 22 working with only a single cylinder; this explains the greater quantity of water found in the steam in the compound tests, and in these experiments the degree of moisture in the steam on leaving the boiler was nearly the same as that found a year later in the tests of 1882 described previously with the ordinary engine A 22.

Thus the results of the two tests on the 7 th of November, agreeing with each other, may be relied on. The same however cannot be said of the test on the 9th of November, which was carried out without any calorimetric verification, and in which a large number of diagrams were failures owing to a fault of the indicator, so that the mean work done by the engine was determined only approximately; for this reason the results of this test cannot be trusted, especially in view of the consumption of steam being here too low.

The sample diagrams from the first experiment on the 7 th of November are shown in Fig. 24, Plate 71. The ordinates of the diagrams from the small cylinder are here to a scale one-half of those from the large cylinder, because they were purposely taken with two different springs; that for the large cylinder was half as strong as the spring for the small cylinder.

As the position of the reversing lever in the first notch corresponded with an admission in the small cylinder of 32 per cent. in the front end and 25 per cent. in the back, and as the volume of the large cylinder was double that of the small, the apparent degree of expansion in these experiments was about seven times. The tests with the compound locomotive have therefore been made with a higher degree of expansion and with a slightly higher boilerpressure than the trials of the ordinary locomotives.

Nevertheless, comparing the results of the tests on the compound engine on the 7 th of November with those on the 21st of July and the 16th of September 1881, made on the ordinary engine A 21 with nearly the same steam-pressure (Tables 5 and 6 ), we find an economy of 17 per cent. in the consumption of steam by the compound locomotive. 


\section{PART II.-Trials made with Experminntal Trains.*}

As it was impossible in the testing shop to carry out experiments with high pressures of steam and late cut-off, owing to the want of a suitable friction-brake, a number of experiments were undertaken in the summer of 1883 with experimental trains, in which were used the same jacketed locomotives, compound A 7 and ordinary engine A 22, previously described, working with and without jackets alternately, and at all possible degrees of expansion and at pressures of from 118 to $132 \mathrm{Ibs}$. above atmosphere.

In order to try the locomotives as far as possible under the usual conditions of work, ordinary mixed and goods trains were selected for the tests, running over the Kieff-Fastoff section of $41 \cdot 10$ miles length.

The experiments here described are divided into four groups :-

(a) Ordinary locomotive with the jackets not working.

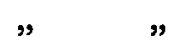

s)

working.

(c) Compound locomotive with the jackets not working. " " " working.

Each engine before being used for the experimental trains was specially overhauled, so as to avoid any accidental defects that might have impaired the proper working during the tests. The tenders of these engines were provided with two graduated water-gauge glasses, placed on the sides of the water tanks, the volume of which had previously been determined with great accuracy. The water gange on the boiler was replaced by that shown in Figs. 8 to 10, Plate 67, having internal baffle-plates for preventing oscillations in the glass tube. The water from the overflow of the injectors was caught in small vessels of known capacity. The water condensed in the steam-jackets was discharged by means of the steam trap shown in

* The whole of this part of the paper is extracted from a detailed report by Mr. L. Loevy, assistant to the locomotive superintendent of the Russian South-Western Railways, who carried out the whole of the trials, and devised the method described of making the calculations. 
Fig. 7, Plate 67, and was run into a measured tank placed underneath the engine and provided with a water-gauge glass.

Each engine was fitted with a counter so placed that it could easily be read from the cab, as well as a Klose speed-indicator, which automatically registered the speed of the engine continuously upon an endless paper ribbon. Each cylinder was provided with indicators, and seats were suitably placed for the observers who took the diagrams. The jackets were provided with pressure-gauges for showing the pressure in them at the time of taking the diagrams; and also for showing, in the tests when the jackets were not at work, whether there was any leakage.

In order to facilitate changing the papers on the indicator barrels, each experimenter had an assistant who removed the diagrams taken and replaced them with fresh papers. The diagrams and papers were passed between the experimenters and assistants by a small endless cord.

The details of the valve-motions while cold are shown in Table 8, on pages 326 and 327.

\section{Mode of conducting the Tests.}

In order that the engine might work during the whole of the test with the reversing lever in the same position, each experimental train had also a pilot engine, coupled on in front of the engine that was being tested. The pilot engine had to give out any extra power necessary for drawing the train. In consequence of the gradients however, the power given out by the locomotive under test was often too great; and it then became necessary to apply the brakes, and sometimes even to close the regulator entirely.

Six experimenters took part in the tests now described. The first controlled the positions of the regulator, as well as of the variable blast-nozzle, and took the readings of the counter, so as to know the particular revolution at which each change was made in the positions of the regulator and blast-nozzle; he also gave signals on the whistle when diagrams were to be taken. The second experimenter had to note every minute the reading of the counter and the boiler pressure. Two experimenters seated on the 
TABLE 8 (continued on opposite page). Details of Talve-Motions.

\begin{tabular}{|c|c|c|c|c|c|c|c|c|}
\hline \multirow{3}{*}{ 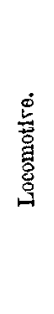 } & \multicolumn{8}{|c|}{ Right-hand Cylinder. } \\
\hline & \multirow{2}{*}{ 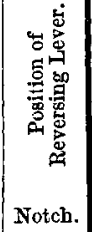 } & \multicolumn{3}{|c|}{ Front end. } & \multicolumn{3}{|c|}{ Back end. } & \multirow[b]{2}{*}{$\begin{array}{l}\text { Travel } \\
\text { of } \\
\text { Valve. }\end{array}$} \\
\hline & & $\begin{array}{c}\text { Cut- } \\
\text { off. } \\
\text { Per cent. }\end{array}$ & $\begin{array}{l}\text { Lead. } \\
\text { Inch. }\end{array}$ & $\begin{array}{c}\text { Maximum } \\
\text { Opening } \\
\text { of } \\
\text { Steam } \\
\text { Port. } \\
\text { Inch. }\end{array}$ & $\begin{array}{c}\begin{array}{c}\text { Cut- } \\
\text { off. } \\
\text { Per cent. }\end{array} \\
\end{array}$ & $\begin{array}{l}\text { Lead. } \\
\text { Inch. }\end{array}$ & $\begin{array}{c}\text { Maximum } \\
\text { Opening } \\
\text { of } \\
\text { Steam } \\
\text { Port. } \\
\text { Inch. }\end{array}$ & \\
\hline 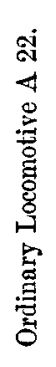 & $\begin{array}{r}1 \\
1 \\
2 \\
3 \\
5 \\
7 \\
11\end{array}$ & $\begin{array}{l}21 \cdot 8 \\
19 \cdot 0 \\
28 \cdot 8 \\
37 \cdot 7 \\
54 \cdot 2 \\
64 \cdot 3 \\
78 \cdot 5\end{array}$ & $\begin{array}{c}? \\
0.256 \\
0.280 \\
0.260 \\
0.201 \\
0.083 \\
-0.004\end{array}$ & $\begin{array}{l}0.331 \\
0.260 \\
0.331 \\
0.370 \\
0.436 \\
0.535 \\
0.743\end{array}$ & $\begin{array}{l}21 \cdot 5 \\
19 \cdot 8 \\
28 \cdot 0 \\
38 \cdot 5 \\
53 \cdot 8 \\
64 \cdot 5 \\
73 \cdot 2\end{array}$ & $\begin{array}{c}? \\
0.071 \\
0.039 \\
0.010 \\
0.030 \\
0.039 \\
-0.030\end{array}$ & $\begin{array}{c}0 \cdot 130 \\
0.091 \\
0 \cdot 128 \\
0.248 \\
0.501 \\
0 \cdot 790 \\
1-073\end{array}$ & $\begin{array}{c}? \\
2 \cdot 34 \\
2 \cdot 44 \\
2 \cdot 64 \\
2 \cdot 95 \\
3 \cdot 31 \\
3 \cdot 82\end{array}$ \\
\hline 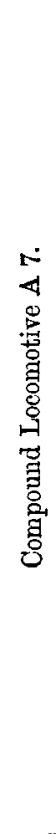 & $\begin{array}{c}" \\
" \\
" \\
70^{\circ} \\
" \\
" \\
" \\
60^{\circ} \\
, \\
" \\
50^{\circ} \\
" \\
"\end{array}$ & $\begin{array}{c}67 \cdot 2 \\
" \\
" \\
" \\
64 \cdot 8 \\
" \\
" \\
" \\
57 \cdot 7 \\
" \\
" \\
49 \cdot 8 \\
" \\
"\end{array}$ & $\begin{array}{c}0 \cdot 138 \\
" \\
" \\
" \\
0 \cdot 187 \\
" \\
" \\
" \\
0 \cdot 246 \\
" \\
" \\
0.310 \\
" \\
" \\
\Rightarrow\end{array}$ & $\begin{array}{c}\text { Large C } \\
0 \cdot 629 \\
" \\
" \\
", \\
0 \cdot 600 \\
" \\
", \\
", \\
0 \cdot 560 \\
, \\
, \\
0 \cdot 541 \\
" \\
"\end{array}$ & \begin{tabular}{|c} 
ylinder. \\
$67 \cdot 2$ \\
$"$ \\
$"$ \\
$"$ \\
$65 \cdot 0$ \\
$"$ \\
$"$ \\
$"$ \\
$57 \cdot 8$ \\
$"$ \\
$"$ \\
$49 \cdot 8$ \\
$"$ \\
$"$ \\
duneersity
\end{tabular} & $\begin{array}{c}0 \cdot 207 \\
" \\
" \\
" \\
0 \cdot 187 \\
" \\
" \\
" \\
0 \cdot 187 \\
" \\
" \\
0 \cdot 167 \\
" \\
" \\
\text { ty Libraries on }\end{array}$ & $\begin{array}{c}1 \cdot 013 \\
" \\
" \\
" \\
0 \cdot 925 \\
" \\
" \\
" \\
0 \cdot 708 \\
" \\
, \\
0 \cdot 541 \\
, \\
" \\
\end{array}$ & $\begin{array}{l}3 \cdot 62 \\
, \\
" \\
" \\
3 \cdot 50 \\
" \\
\text { " } \\
\text { " } \\
3 \cdot 25 \\
, \\
\text { " } \\
\text { " } \\
\text { " }\end{array}$ \\
\hline
\end{tabular}


Details of Valve-Motions. (continued from opposite page) TABLE 8.

\begin{tabular}{|c|c|c|c|c|c|c|c|c|}
\hline \multicolumn{8}{|c|}{ Left-hand Cylinder. } & \multirow[b]{3}{*}{ Tests. } \\
\hline$\dot{\Delta}$ & \multicolumn{3}{|c|}{ Front end. } & \multicolumn{3}{|c|}{ Back end. } & \multirow[b]{2}{*}{$\begin{array}{l}\text { Travel } \\
\text { of } \\
\text { Valve. } \\
\text { Inches. }\end{array}$} & \\
\hline 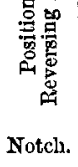 & $\begin{array}{l}\text { Cut- } \\
\text { off. } \\
\text { Per cent. }\end{array}$ & $\begin{array}{l}\text { Lead. } \\
\text { Inch. }\end{array}$ & $\begin{array}{c}\text { Maximum } \\
\text { Opening } \\
\text { of } \\
\text { Steam } \\
\text { Port. } \\
\text { Inch. }\end{array}$ & $\begin{array}{c}\begin{array}{c}\text { Cut- } \\
\text { off. } \\
\text { Per cent. }\end{array} \\
\end{array}$ & $\begin{array}{l}\text { Lead. } \\
\text { Inch. }\end{array}$ & $\left\{\begin{array}{c}\text { Maximum } \\
\text { Opening } \\
\text { of } \\
\text { Steam } \\
\text { Port. } \\
\text { Inch. }\end{array}\right.$ & & \\
\hline $\mathbf{1}$ & $22 \cdot 7$ & $?$ & $0 \cdot 295$ & $22 \cdot 3$ & $?$ & $0 \cdot 177$ & $?$ & 1 \\
\hline 1 & $21 \cdot 7$ & 0.266 & $0 \cdot 276$ & $22 \cdot 2$ & $0 \cdot 069$ & $0 \cdot 118$ & $2 \cdot 36$ & 13,15 \\
\hline 2 & $32 \cdot 3$ & $0 \cdot 266$ & 0.325 & $31 \cdot 7$ & 0.039 & $0 \cdot 158$ & $2 \cdot 16$ & 16,17 \\
\hline 3 & $4 \mathrm{I} \cdot 8$ & $0 \cdot 246$ & $0 \cdot 364$ & $41 \cdot 5$ & 0.020 & 0.276 & $2 \cdot 64$ & 7,8 \\
\hline 5 & $57 \cdot 0$ & $0 \cdot 167$ & 0.452 & $56 \cdot 8$ & 0.039 & 0.541 & $2 \cdot 95$ & 9,10 \\
\hline 7 & $67 \cdot 5$ & 0.069 & 0.570 & $67 \cdot 0$ & $0 \cdot 059$ & $0 \cdot 836$ & $3 \cdot 35$ & $11 b, 12 b$ \\
\hline 11 & 80.5 & $-0 \cdot 059$ & $0 \cdot 817$ & $74 \cdot 5$ & -0.059 & $1 \cdot 102$ & $3 \cdot 86$ & $11 a, 12 a$ \\
\hline \multicolumn{8}{|c|}{ Small Cylinder. } & \\
\hline $\mathbf{1}$ & $45 \cdot 3$ & $0 \cdot 285$ & 0.442 & $45 \cdot 6$ & 0.049 & $0 \cdot 335$ & $2 \cdot 66$ & 13,14 \\
\hline 3 & $60 \cdot 7$ & $0 \cdot 217$ & 0.551 & $60 \cdot 5$ & 0.059 & 0.610 & $3 \cdot 01$ & 15,16 \\
\hline 5 & $70 \cdot 5$ & 0.089 & $0 \cdot 600$ & $70 \cdot 5$ & 0.039 & 0.885 & $3 \cdot 35$ & 17,18 \\
\hline 7 & $77 \cdot 0$ & -0.059 & 0.688 & $76 \cdot 8$ & 0.049 & $1 \cdot 151$ & $3 \cdot 70$ & 19,20 \\
\hline 1 & $40 \cdot 9$ & $0 \cdot 325$ & 0.413 & $40 \cdot 9$ & 0.059 & 0.256 & $2 \cdot 58$ & 5,6 \\
\hline 3 & $57 \cdot 2$ & $0 \cdot 236$ & 0.521 & $57 \cdot 0$ & 0.049 & 0.551 & $2 \cdot 93$ & 7,8 \\
\hline 5 & $68 \cdot 3$ & 0.128 & $0 \cdot 600$ & $68 \cdot 3$ & 0.079 & $0 \cdot 866$ & $3 \cdot 33$ & 9,10 \\
\hline 7 & $75 \cdot 2$ & 0.010 & 0.688 & $75 \cdot 3$ & 0.079 & $1 \cdot 122$ & $3 \cdot 66$ & 11,12 \\
\hline 1 & $30 \cdot 7$ & 0.325 & $0 \cdot 354$ & $30 \cdot 3$ & 0.059 & $0 \cdot 128$ & $2 \cdot 38$ & 21,22 \\
\hline 4 & $56 \cdot 2$ & 0.256 & $0 \cdot 491$ & $56 \cdot 3$ & 0.049 & 0.531 & $2 \cdot 91$ & 23,24 \\
\hline 7 & $73 \cdot 3$ & 0.059 & 0.639 & $73 \cdot 3$ & 0.020 & 0.925 & $3 \cdot 41$ & 25,26 \\
\hline 1 & $22 \cdot 5$ & $0 \cdot 295$ & 0.315 & $22 \cdot 2$ & $0 \cdot 089$ & $0 \cdot 108$ & $2 \cdot 26$ & 27,28 \\
\hline 4 & $49 \cdot 5$ & 0.285 & 0.442 & $49 \cdot 5$ & 0.059 & $0 \cdot 394$ & $2 \cdot 68$ & 29,30 \\
\hline 7 & $69 \cdot 0$ & 0.089 & 0.560 & $69 \cdot 3$ & 0.049 & 0.807 & $3 \cdot 25$ & 31,32 \\
\hline
\end{tabular}


front of the locomotive took the diagrams when they received the signals; and the remaining two changed the diagram papers on the indicator drums. One of these last checked the water-levels in the tender and boiler at each station, estimated the quantity of water lost from the injector overflows, and measured the quantity of wood burnt.

Special care was taken in each test to obtain the whole of the data necessary for determining as accurately as possible the work done by the engine during the run, as well as the consumption of water and fuel. For this purpose the experimenters noted the following points during each test:-

(1) The speed of the train by means of the Klose speedindicator.

(2) The number of revolutions of the driving wheels as shown by the counter, before starting, and at each successive minute of the run, and at each shifting of the regulator and of the variable blast-nozzle, and at each time of taking diagrams, and when the run was concluded. By this means accurate indications were obtained of the number of revolutions made during each position of the regulator and of the blast-nozzle, as well as of their positions at each moment.

(3) The boiler pressure, every minute and at each time of taking diagrams.

(4) The pressure in the steam-jackets.

(5) The mean work done in the cylinders, as measured from the indicator diagrams, which were taken with Rosenkranz indicators from both ends of the cylinders as often as possible, sometimes every minute, and whenever changes occurred either in speed or in pressure or in position of regulator or of blast-nozzle, \&c.

(6) The consumption of moist steam.

(7) The consumption of wood.

(8) The quantity of steam condensed in the jackets.

Unfortunately the water-gauge glasses on the vessels that collected the condensed water from the jackets were continually getting broken, owing to the line being under repair, and the water was lost on the road. During two tests only was it possible to 
estimate the quantity of water condensed in the jackets, and even then there was no certainty that the jackets had been thoroughly drained.

\section{Calculation of Work done.}

If the mean forward pressures and back-pressures in each end of each cylinder are known, and also the number of revolutions made with these mean pressures, the indicated power developed by the engine during that number of revolutions can be calculated. The mean forward pressure $p$ in the cylinder, for the same position of the reversing lever and of the regulator, and for the same speed, depends on the absolute boiler-pressure $P$, and may be taken as proportional to it, that is to say $p=n P$; but the coefficient $n$ of this proportion will vary for different speeds. The same remarks apply also to the mean back-pressures in the small cylinder of the compound engine.

By the aid of the several diagrams taken during each test, curves were drawn for each test showing for both ends of each cylinder how the percentage $n$ varies with the number of revolutions per minute. In Figs. 25 to 30 , Plate 72, are shown these curves for test No. 13 with the compound engine A 7. The curves in Figs. 25 and 26 give the percentages for the mean forward pressures in the front and back ends of the small cylinder; the curves in Figs. 27 and 28 for the mean back-pressures in the front and back ends of the small cylinder; and the curves in Figs. 29 and 30 show the percentages for the mean forward pressures in the front and back ends of the large cylinder. In all these curves the abscisso are proportional to the number of revolutions per minute, and the ordinates give the values of the coefficient $n$ in percentage of the absolute boiler-pressure.

As regards the mean back-pressure in the cylinders of the ordinary engine, as well as in the large cylinder of the compound engine, this does not depend, or depends in only a very small degree on the boiler pressure; but it depends on the number of revolutions per minute, and on the position of the blast-nozzle. For each test therefore, and for each position of the blast-nozzle, curves have been 
drawn showing for both ends of the cylinder how the mean backpressures vary with the number of revolutions per minute. In Figs. 31 and 32, Plate 72, are given these curves for test No. 13 when the blast-nozzle was fully open.

By the aid of all these curves can be determined, for each number of revolutions per minute and each boiler-pressure, the mean forward pressures and back-pressures in each end of each cylinder. From the speed-indicator diagram obtained separately for each test, as shown in Fig. 33, Plate 73, and from the total number of revolutions shown by the counter for the whole of the test, the number of revolutions made by the engine during periods not exceeding one minute was calculated; thence the mean number of revolutions per minute for this period; and finally the mean forward pressures and back-pressures in the cylinders corresponding with this number and with the boiler-pressures during the same period.

Having obtained these data, it was possible to calculate the amount of indicated work done by the engine during this period; and by taking the sum of all these quantities for the whole test, the total power exerted during the whole test was thus arrived at.

All this necessitated a large number of minute and complicated calculations, involving much time and labour, but enabling the power exerted to be determined very accurately.

Consumption of Water and Fuel per I.H.P. per hour.

No conclusion could be drawn from several of the trips, on account of minor accidents or partial failures. The results obtained with ordinary engine A 22 and compound A 7 in the runs which were completed satisfactorily are grouped in Table 9, pages 332-3, following the order in which the tests were made. Some indicator diagrams from the ordinary engine A 22 are shown in Plates 74 and 75 , and from the compound engine $A 7$ in Plates 76 to 79 . As seen in Table 9, the tests were made at six different positions of the reversing lever for the ordinary engine A 22, and at fourteen different positions for the compound engine A 7 . 
'The degree of apparent expansion (neglecting the clearances), corresponding with each position of the reversing lever for each engine, is shown in column 4. The figures given for the compound engine A 7 have been estimated on the supposition that the whole expansion took place in a single cylinder having a volume equal to that of the large cylinder.

In order to be able to appreciate the effect of the degree of opening of the regulator on the loss of pressure by the steam in its passage to the steam-chest, the mean openings of the regulator for each test are given in column 15 of Table 9. From the figures in columns 14 and 15 the weight of steam passing per minute per square inch through the regulator opening has been calculated, and is given in column 16. Clearly the pressure of the steam ought to diminish in its passage from the regulator to the cylinders, and this loss ought to increase with the increase of velocity of the steam through the opening of the regulator as well as through the steam ports. As a matter of fact, on examining the diagrams from each test, it is perceived that changes of position of the regulator have produced very large losses of pressure: while the mean initial pressure in the small cylinder of the compound engine A 7 differed less than 10 per cent. from the mean boiler-pressure and averaged 95 per cent. of the latter, the mean initial pressure in the cylinders of the ordinary locomotive A 22 was 95 per cent. for tests Nos. 13 and $17 ; 93$ per cent. for tests Nos. 8,15 , and $16 ; 90$ per cent. for No. $1 ; 80$ and 74 per cent. for Nos. 9,10 , and $7 ; 64$ per cent. for No. $11 a$; 55 per cent. for No. $11 b$; and only 53 per cent. of the boiler-pressure for test No. $12 a$. It is therefore clear that only tests Nos. 13, 17, 8, 15, 16, and 1 of the ordinary engine A 22 can be compared with the tests of the compound locomotive A 7 .

The figures given in column 8, Table 9, show very different weights of water evaporated per pound of wood in each test. The principal cause of these differences lies in the difficulty of measuring by eye the quantity of wood on the grate at the beginning and end of each test. In order as far as possible to compensate for this error of observation, a mean was taken of all the tests made with each engine, and it was found that the ordinary engine A 22 
TABLE 9 (continued on opposite page).

Details of Running.

\begin{tabular}{|c|c|c|c|c|c|c|}
\hline 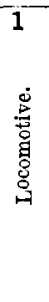 & 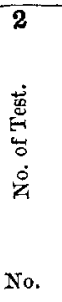 & 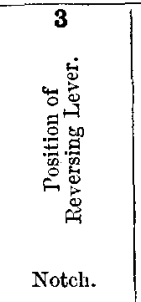 & 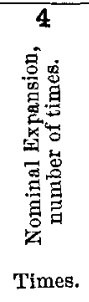 & 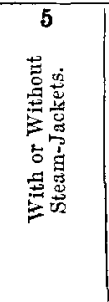 & $\begin{array}{c}6 \\
\text { Names of Stations } \\
\text { between which } \\
\text { the tests } \\
\text { were carried out. }\end{array}$ & 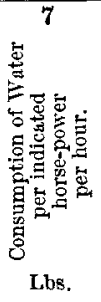 \\
\hline 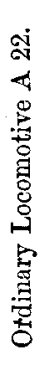 & $\begin{array}{l}1 \\
7 \\
8 \\
9 \\
10 \\
11 a \\
11 b \\
12 a \\
12 b \\
13 \\
15 \\
16 \\
17\end{array}$ & $\begin{array}{r}1 \\
3 \\
3 \\
5 \\
5 \\
11 \\
7 \\
11 \\
7 \\
1 \\
1 \\
2 \\
2\end{array}$ & $\begin{array}{l}4 \cdot 5 \\
2 \cdot 5 \\
2 \cdot 5 \\
1 \cdot 8 \\
1 \cdot 8 \\
1 \cdot 3 \\
1 \cdot 5 \\
1 \cdot 3 \\
1 \cdot 5 \\
4 \cdot 8 \\
4 \cdot 8 \\
3 \cdot 3 \\
3 \cdot 3\end{array}$ & $\begin{array}{c}\text { without } \\
\text { without } \\
\text { with } \\
\text { without } \\
\text { with } \\
\text { without } \\
\text { without } \\
\text { with } \\
\text { with } \\
\text { without } \\
\text { with } \\
\text { without } \\
\text { with }\end{array}$ & $\begin{array}{c}\text { Kieff-Fastoff } \\
\qquad " \\
", \\
\text { Kieff-Boiarka } \\
\text { Boiarka-Fastoff } \\
\text { Kieff-Boiarka } \\
\text { Boiarka-Fastoff } \\
\text { Kieff-Fastoff } \\
\text { ", } \\
"\end{array}$ & $\begin{array}{l}28 \cdot 11 \\
28 \cdot 59 \\
27 \cdot 78 \\
31 \cdot 17 \\
30 \cdot 49 \\
40 \cdot 37 \\
35 \cdot 45 \\
40 \cdot 54 \\
35 \cdot 19 \\
27 \cdot 93 \\
24 \cdot 82 \\
26 \cdot 76 \\
26 \cdot 74\end{array}$ \\
\hline 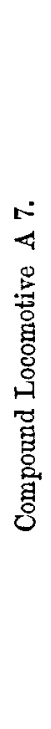 & $\begin{array}{r}5 \\
6 \\
7 \\
8 \\
9 \\
10 \\
11 \\
12 \\
13 \\
14 \\
15 \\
16 \\
17 \\
18 \\
19 \\
20 \\
21 \\
22 \\
23 \\
24 \\
25 \\
26 \\
27 \\
29 \\
30 \\
31 \\
32\end{array}$ & 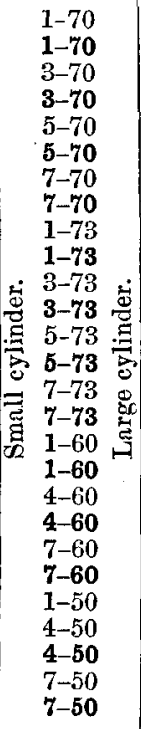 & $\begin{array}{l}5 \cdot 0 \\
5 \cdot 0 \\
3 \cdot 6 \\
3 \cdot 6 \\
3 \cdot 0 \\
3 \cdot 0 \\
2 \cdot 7 \\
2 \cdot 7 \\
4 \cdot 5 \\
4 \cdot 5 \\
3 \cdot 4 \\
3 \cdot 4 \\
2 \cdot 9 \\
2 \cdot 9 \\
2 \cdot 7 \\
2 \cdot 7 \\
6 \cdot 7 \\
6 \cdot 7 \\
3 \cdot 6 \\
3 \cdot 6 \\
2 \cdot 8 \\
2 \cdot 8 \\
9 \cdot 1 \\
4 \cdot 1 \\
4 \cdot 1 \\
3 \cdot 0 \\
3 \cdot 0\end{array}$ & $\begin{array}{l}\text { without } \\
\text { with } \\
\text { without } \\
\text { with } \\
\text { without } \\
\text { with } \\
\text { without } \\
\text { with } \\
\text { without } \\
\text { with } \\
\text { without } \\
\text { with } \\
\text { without } \\
\text { with } \\
\text { without } \\
\text { with } \\
\text { without } \\
\text { with } \\
\text { without } \\
\text { with } \\
\text { without } \\
\text { with } \\
\text { without } \\
\text { without } \\
\text { with } \\
\text { without } \\
\text { with }\end{array}$ & $\begin{array}{l}\text { Kieff-Fastoff } \\
\text { Fastoff-Kieff } \\
\text { Kieff-Fastoff } \\
\text { Fastoff-Kieff } \\
\text { Kieff-Fastoff } \\
\text { Fastoff-Kieff } \\
\text { Kieff-Fastoff } \\
\text { Fastoff-Kieff } \\
\text { Kieff-Fastoff } \\
\text { Motovilowka-Kieff } \\
\text { Kieff-Fastoff } \\
\text { Fastoff-Kieff } \\
\text { Kieff-Fastoff } \\
\text { Motovilowka-Kieff } \\
\text { Kieff-Fastoff } \\
\text { Fastoff-Kieff } \\
\text { Kieff-Fastoff } \\
\text { Fastoff-Kieff } \\
\text { Kieff-Fastoff } \\
\text { Fastoff-Kieff } \\
\text { Kieff-Fastoff } \\
\text { Fastoff-Kieff } \\
\text { Kieff-Fastoff } \\
\text { Fastof'-Kieff } \\
\text { Kieff-Fastoff } \\
\text { Fastoff-Kieff }\end{array}$ & $\begin{array}{l}22 \cdot 62 \\
22 \cdot 31 \\
23 \cdot 77 \\
23 \cdot 17 \\
23 \cdot 90 \\
25 \cdot 09 \\
24 \cdot 69 \\
24 \cdot 23 \\
22 \cdot 07 \\
24 \cdot 71 \\
22 \cdot 69 \\
26 \cdot 15 \\
24 \cdot 58 \\
25 \cdot 24 \\
25 \cdot 24 \\
27 \cdot 93 \\
19 \cdot 95 \\
23 \cdot 21 \\
22 \cdot 16 \\
25 \cdot 44 \\
23 \cdot 88 \\
25 \cdot 53 \\
23 \cdot 68 \\
23 \cdot 28 \\
25 \cdot 20 \\
23 \cdot 70 \\
25 \cdot 46\end{array}$ \\
\hline
\end{tabular}


Details of Running. $\quad$ (continued from opposite page) TABLE 9.

\begin{tabular}{|c|c|c|c|c|c|c|c|c|}
\hline \multirow{3}{*}{ 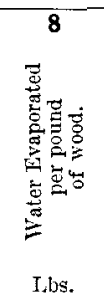 } & \multirow{3}{*}{ 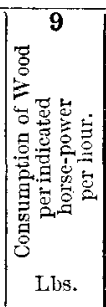 } & 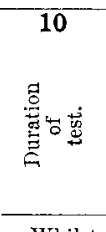 & 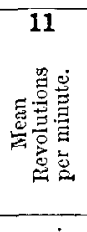 & 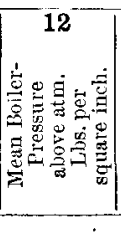 & 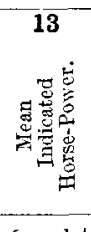 & 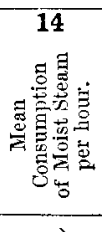 & \multirow{3}{*}{ 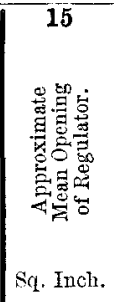 } & \multirow{3}{*}{ 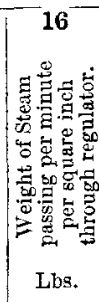 } \\
\hline & & \multicolumn{5}{|c|}{ Whilst the engine was running (regulator open). } & & \\
\hline & & Minutes. & Revs. & Lus. & I. H.P. & Ibs. & & \\
\hline $\begin{array}{l}\mathbf{3} \cdot 25 \\
3 \cdot 79 \\
3 \cdot 56 \\
3 \cdot 28 \\
\mathbf{3} \cdot 17 \\
3 \cdot 20\end{array}$ & $\begin{array}{r}8 \cdot 64 \\
7 \cdot 54 \\
7 \cdot 80 \\
9 \cdot 50 \\
9 \cdot 63 \\
12 \cdot 61 \\
11 \cdot 07 \\
13 \cdot 10 \\
11 \cdot 38 \\
8 \cdot 25 \\
8 \cdot 55 \\
7 \cdot 10 \\
7 \cdot 36\end{array}$ & $\begin{array}{c}121 \cdot 5 \\
95 \cdot 5 \\
95 \\
96 \cdot 5 \\
100 \cdot 5 \\
49 \\
72 \\
33 \cdot 5 \\
57 \cdot 5 \\
118 \\
102 \cdot 5 \\
123 \cdot 5 \\
112 \cdot 5\end{array}$ & $\begin{array}{l}76 \\
79 \\
\mathbf{7 9} \\
83 \\
\mathbf{8 3} \\
62 \\
80 \\
\mathbf{9 1} \\
\mathbf{9 9} \\
87 \\
\mathbf{9 2} \\
71 \\
74\end{array}$ & $\begin{array}{l}127 \cdot 5 \\
121 \cdot 8 \\
114 \cdot 7 \\
119 \cdot 0 \\
100 \cdot 5 \\
116 \cdot 2 \\
123 \cdot 3 \\
121 \cdot 8 \\
123 \cdot 3 \\
121 \cdot 8 \\
126 \cdot 1 \\
121 \cdot 8 \\
116 \cdot 2\end{array}$ & $\begin{array}{l}164 \\
226 \\
248 \\
272 \\
257 \\
190 \\
241 \\
230 \\
279 \\
187 \\
200 \\
209 \\
215\end{array}$ & $\begin{array}{l}4612 \\
6453 \\
\mathbf{6 8 9 6} \\
8475 \\
\mathbf{7 8 5 1} \\
7687 \\
8543 \\
\mathbf{9 3 1 9} \\
\mathbf{9 8 2 1} \\
5247 \\
4967 \\
5593 \\
5750\end{array}$ & $\begin{array}{l}0 \cdot 445 \\
0 \cdot 268 \\
0.998 \\
0 \cdot 691 \\
0 \cdot 626 \\
0 \cdot 205 \\
0 \cdot 202 \\
0.129 \\
0.353 \\
1 \cdot 356 \\
0 \cdot 890 \\
1 \cdot 076 \\
1 \cdot 928\end{array}$ & $\begin{array}{r}172 \\
401 \\
115 \\
205 \\
209 \\
626 \\
701 \\
1208 \\
464 \\
64 \\
92 \\
98 \\
50\end{array}$ \\
\hline $\begin{array}{l}3 \cdot 23 \\
3 \cdot 05 \\
3 \cdot 78 \\
4 \cdot 04 \\
3 \cdot 51 \\
4 \cdot 15 \\
3 \cdot 59 \\
4 \cdot 06 \\
4 \cdot 04 \\
\mathbf{4} \cdot 10 \\
3 \cdot 65 \\
4 \cdot 40 \\
4 \cdot 01 \\
4 \cdot 01 \\
3 \cdot 64 \\
\mathbf{4} \cdot 23 \\
3 \cdot 95 \\
\mathbf{3} \cdot 56 \\
\mathbf{3} \cdot 76 \\
\mathbf{4} \cdot \mathbf{3 3} \\
3 \cdot 77 \\
\mathbf{4} \cdot 42 \\
3 \cdot 62 \\
3 \cdot 66 \\
\mathbf{4} \cdot \mathbf{4 5} \\
\mathbf{3} \cdot 30 \\
\mathbf{3} \cdot 99\end{array}$ & $\begin{array}{l}7 \cdot 01 \\
7 \cdot 32 \\
6 \cdot 28 \\
5 \cdot 73 \\
6 \cdot 81 \\
6 \cdot 04 \\
6 \cdot 88 \\
5 \cdot 97 \\
5 \cdot 47 \\
6 \cdot 02 \\
6 \cdot 22 \\
5 \cdot 93 \\
6 \cdot 13 \\
6 \cdot 28 \\
6 \cdot 94 \\
6 \cdot 61 \\
5 \cdot 05 \\
6 \cdot 53 \\
5 \cdot 89 \\
5 \cdot 89 \\
6 \cdot 33 \\
5 \cdot 78 \\
6 \cdot 50 \\
6 \cdot 37 \\
5 \cdot 67 \\
7 \cdot 19 \\
6 \cdot 39\end{array}$ & $\begin{array}{c}95 \\
84 \cdot 5 \\
91 \\
77 \\
92 \\
78 \\
84 \\
69 \cdot 5 \\
111 \\
65 \\
106 \cdot 5 \\
68 \\
100 \\
57 \\
77 \cdot 5 \\
60 \\
109 \cdot 5 \\
80 \\
97 \\
75 \cdot 5 \\
82 \\
71 \\
135 \\
110 \\
72 \cdot 5 \\
94 \\
80\end{array}$ & $\begin{array}{r}90 \\
99 \\
95 \\
104 \\
92 \\
92 \\
90 \\
107 \\
79 \\
104 \\
87 \\
88 \\
88 \\
102 \\
112 \\
115 \\
86 \\
\mathbf{9 9} \\
85 \\
81 \\
98 \\
94 \\
73 \\
84 \\
102 \\
91 \\
\mathbf{9 2}\end{array}$ & $\begin{array}{l}127 \cdot 5 \\
117 \cdot 6 \\
123 \cdot 3 \\
129 \cdot 0 \\
126 \cdot 8 \\
121 \cdot 1 \\
122 \cdot 6 \\
126 \cdot 8 \\
129 \cdot 7 \\
117 \cdot 6 \\
131 \cdot 1 \\
113 \cdot 3 \\
123 \cdot 3 \\
124 \cdot 7 \\
121 \cdot 8 \\
107 \cdot 6 \\
127 \cdot 5 \\
123 \cdot 3 \\
120 \cdot 4 \\
111 \cdot 2 \\
123 \cdot 3 \\
112 \cdot 6 \\
133 \cdot 2 \\
124 \cdot 0 \\
114 \cdot 0 \\
131 \cdot 1 \\
121 \cdot 8\end{array}$ & $\begin{array}{r}172 \\
198 \\
216 \\
253 \\
245 \\
226 \\
259 \\
307 \\
172 \\
168 \\
235 \\
1577 \\
239 \\
277 \\
323 \\
273 \\
135 \\
128 \\
195 \\
164 \\
261 \\
229 \\
85 \\
160 \\
161 \\
216 \\
229\end{array}$ & $\begin{array}{l}3882 \\
4416 \\
5124 \\
5871 \\
5860 \\
5661 \\
6409 \\
7452 \\
3785 \\
4147 \\
5326 \\
4118 \\
5869 \\
7006 \\
8153 \\
7641 \\
2687 \\
2965 \\
4330 \\
4178 \\
6226 \\
5860 \\
2022 \\
3737 \\
4063 \\
5128 \\
5836\end{array}$ & $\begin{array}{r}15 \cdot 742 \\
17 \cdot 148 \\
12 \cdot 355 \\
16 \cdot 291 \\
10 \cdot 579 \\
10 \cdot 284 \\
11 \cdot 064 \\
15 \cdot 114 \\
15 \cdot 502 \\
6 \cdot 323 \\
14 \cdot 607 \\
4 \cdot 475 \\
10 \cdot 502 \\
14 \cdot 191 \\
13 \cdot 913 \\
9 \cdot 260 \\
14 \cdot 144 \\
15 \cdot 077 \\
11 \cdot 413 \\
6 \cdot 809 \\
13 \cdot 713 \\
12 \cdot 090 \\
17 \cdot 725 \\
15 \cdot 624 \\
14 \cdot 119 \\
8 \cdot 003 \\
12 \cdot 910\end{array}$ & $\begin{array}{r}4 \\
4 \\
7 \\
6 \\
9 \\
9 \\
10 \\
9 \\
4 \\
11 \\
6 \\
16 \\
9 \\
9 \\
10 \\
14 \\
3 \\
3 \\
6 \\
10 \\
7 \\
9 \\
1 \\
4 \\
4 \\
11 \\
7\end{array}$ \\
\hline
\end{tabular}


evaporated $3.33 \mathrm{lbs}$. of water per pound of wood, and the compound engine A 7 evaporated $3.82 \mathrm{Ibs}$; ; that is to say, the compound engine A 7 evaporated 14.6 per cent. more water per pound of wood.* These mean figures have been used in the following calculations.

\section{Comparative Consumption of Water and Fuel}

in Compound and Ordinary locomotives expanding equally.

In Table 10, pages 336-7, are given the results of the tests, following the order of decreasing expansion.

An examination of this 'Table shows that only tests Nos. 1, 13,15, 16 , and 17, made in the first and second notch with the ordinary engine A 22, come within the limits of expansion employed in the compound engine A 7. Moreover for tests Nos. 13, 15, 16, and 17 , of the ordinary engine $A$ 22, there are no tests of the compound engine A 7 carried out with exactly corresponding expansion; so that, in order to make exact comparisons, it is necessary to find theconsumptions of water and fuel in the compound engine $A 7$ for expansions equal to those which took place during tests Nos. 13 . and 16.

On account of causes which are described further on (pp. 343-5), the comparisons will only be made between tests carried out when the jackets were not at work. The tests without jackets on the compound engine A 7 were made with average boiler-pressures very slightly varying, and ranging from 120 to $133 \mathrm{lbs}$. per square inch above atmosphere; that is to say, within nearly the same limits as. tests Nos. 13, 16, and 1, with the ordinary engine A 22. The slight variations of pressure in these tests may therefore be neglected. On the other hand the speed (average number of revolutions per minute) varies considerably for the compound A 7 and ordinary engine A 22. Comparing test No. 7 with No. 23, and test No. 11 with No. 19, carried out on the compound engine A 7 with a nearly equal pressure but at a different speed, we find greater consumptions at higher speeds. It may therefore be admitted that the consumptions of

* Part of this result to the credit of the compound engine A 7 may be attributed to the stoker's care, as well as to the want of uniformity in the wood used. 
steam in the ordinary engine A 22 are less than they would have been if the mean speed had been as high as in the tests of the compound engine A 7 .

Taking two rectangular co-ordinates, Fig. 34, Plate 73, and laying off on the abscissa lengths proportional to the degree of expansion, and on the corresponding ordinates lengths proportional to the consumption of water in lbs. per indicated horse-power per hour, as ascertained in each test of the compound engine, a series of points are obtained which are marked in the diagram with the numbers of the tests, and through which is drawn a curve representing with sufficient accuracy for the compound engine how the consumption of water varies with the degree of expansion. For an expansion of 4.8 times, corresponding with test No. 13 of the ordinary engine A 22, this curve gives a consumption of $21 \cdot 83 \mathrm{lbs}$. of water for the compound engine; and for an expansion of $3 \cdot 3$ times, corresponding with test No. 16 of the ordinary engine A 22, a consumption of 23.15 lbs. Comparing these figures with the corresponding figures of the consumption in the ordinary engine A 22 (for test No. $13=27 \cdot 93$, and for test No. $16=26 \cdot 76 \mathrm{lbs}$.), it is seen that the compound engine, in comparison with the ordinary engine A 22, gives with 4.8 times expansion an economy of 22 per cent., and with $3 \cdot 3$ times expansion an economy of 13 per cent. in consumption of steam per indicated horse-power.

Comparing test No. 13 of the compound engine with test No. 1 of the ordinary engine A 22 carried out with the same expansion of 4.5 times, the compound engine shows an economy of 21 per cent. in consumption of steam.

If the curve in Fig. 34, Plate 73, be continued towards the left, as shown dotted, it is found that the consumption of steam with an expansion of 2.5 times will be about $26.23 \mathrm{lbs}$. for the compound engine. Comparing this consumption with that in test No. 7 of the ordinary engine A 22 , namely $28.59 \mathrm{lbs}$, there is found an economy of 9 per cent. for the compound engine.

Turning from the consumption of water to the consumption of fuel per indicated horse-power per hour, and bearing in mind that the mean evaporation in the ordinary engine A 22 was $3.33 \mathrm{lbs}$. 
TABLE 10 (continued on opposite page). Water Consumption in Ordinary

\begin{tabular}{|c|c|c|c|c|c|c|c|c|c|}
\hline \multirow{4}{*}{ 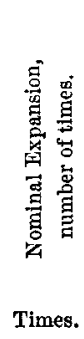 } & \multicolumn{9}{|c|}{ Ordinary Locomotive A 22.} \\
\hline & \multicolumn{4}{|c|}{ Without jackets. } & \multicolumn{4}{|c|}{ With jackets. } & \multirow{3}{*}{$\begin{array}{c}\text { Economy } \\
\text { produced } \\
\text { by Jackets, } \\
\text { percentage of } \\
\text { consumption } \\
\text { of steam } \\
\text { without } \\
\text { jackets. } \\
\text { Per cent. }\end{array}$} \\
\hline & 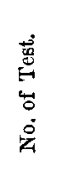 & 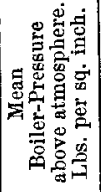 & 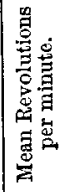 & 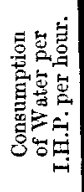 & 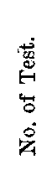 & 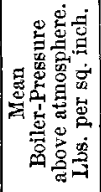 & 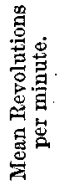 & 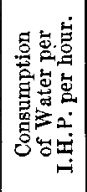 & \\
\hline & No. & Lbs. & Revs. & Lbs. & No. & Lbs. & Rers. & Lbs.. & \\
\hline $9 \cdot 1$ & .. & .. & .. & .. & .. & .. & .. & .. & .. \\
\hline $6 \cdot 7$ & .. & .. & .. & .. & .. & .. & .. & .. & .. \\
\hline $5 \cdot 0$ & .. & .. & .. & .. & .. & .. & .. & .. & .. \\
\hline $4 \cdot 8$ & 13 & $121 \cdot 8$ & 87 & $27 \cdot 93$ & 15 & $126 \cdot 1$ & 92 & $24 \cdot 82$ & $+11 \cdot 9$ \\
\hline $4 \cdot 5$ & 1 & $127 \cdot 5$ & 76 & $28 \cdot 11$ & .. & .. & .. & .. & .. \\
\hline $4 \cdot 1$ & .. & .. & .. & .. & .. & .. & .. & .. & .. \\
\hline $3 \cdot 6$ & .. & .• & .. & .. & .. & .. & .. & .. & .. \\
\hline $3: 4$ & .. & .. & .. & .. & .. & .. & .. & .. & .. \\
\hline $\mathbf{3} \cdot \mathbf{3}$ & 10 & $121 \cdot 8$ & 71 & $26 \cdot 76$ & 17 & $116 \cdot 2$ & 74 & $26 \cdot 74$ & +0.07 \\
\hline $3 \cdot 0$ & .. & .. & .. & .. & .. & .. &.. & .. & *. \\
\hline $2 \cdot 9$ & .. & .. & .. & .. & .. & .. & .. & .. & .. \\
\hline $2 \cdot 8$ & .. & $\because$ & .. & .. & .. & .. & .. & .. & .. \\
\hline $2 \cdot 7$ & .. & .. & .. & .. & .. & .. & .. & $\cdots$ & .. \\
\hline $2 \cdot 5$ & 7 & $121 \cdot 8$ & 79 & $28 \cdot 59$ & 8 & $114 \cdot 7$ & 79 & $27 \cdot 78$ & $+2 \cdot 8$ \\
\hline $1 \cdot 8$ & 9 & $119 \cdot 0$ & 83 & $31 \cdot 17$ & 10 & $100 \cdot 5$ & 83 & $30 \cdot 49$ & $+2 \cdot 2$ \\
\hline $1 \cdot 5$ & $11 b$ & $123 \cdot 3$ & 80 & $35 \cdot 45$ & $12 b$ & $123 \cdot 3$ & 99 & $35 \cdot 19$ & +0.7 \\
\hline $1 \cdot 3$ & $11 a$ & $116 \cdot 2$ & 62 & $40 \cdot 37$ & $12 a$ & $121 \cdot 8$ & 91 & $40 \cdot 54$ & -0.4 \\
\hline
\end{tabular}


and Compound Locomotive. (continued from opposite page) TABLE 10.

\begin{tabular}{|c|c|c|c|c|c|c|c|c|c|}
\hline \multirow{4}{*}{ 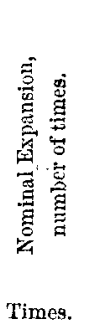 } & \multicolumn{9}{|c|}{ Compound Locomotive A 7.} \\
\hline & \multicolumn{4}{|c|}{ Without jackets. } & \multicolumn{4}{|c|}{ With jackets. } & \multirow{3}{*}{$\begin{array}{c}\text { Economy } \\
\text { produced } \\
\text { by Jackets, } \\
\text { percentage of } \\
\text { consumption } \\
\text { of steam } \\
\text { without } \\
\text { jackets. } \\
\text { Per cent. }\end{array}$} \\
\hline & 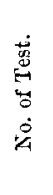 & 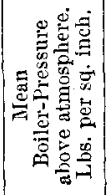 & 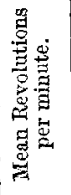 & 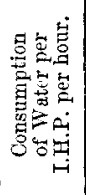 & 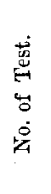 & 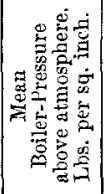 & 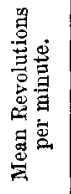 & 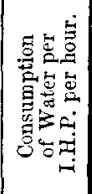 & \\
\hline & No. & Lbs. & Revs. & Labs. & No. & Lbs. & Revs. & Lbs. & \\
\hline $9 \cdot 1$ & 27 & $133 \cdot 2$ & 78 & $23 \cdot 68$ & .. & .. & .. & .. & .. \\
\hline $6 \cdot 7$ & 21 & $127 \cdot 5$ & 86 & $19 \cdot 95$ & 22 & $123 \cdot 3$ & 99 & $23 \cdot 21$ & $-16 \cdot 4$ \\
\hline $5 \cdot 0$ & 5 & $127 \cdot 5$ & 90 & $22 \cdot 62$ & 6 & $117 \cdot 6$ & 99 & $22 \cdot 31$ & $+1 \cdot 3$ \\
\hline $4 \cdot 8$ & . & .. & .. & .. & .. & .. & .. & .. & .. \\
\hline $4 \cdot 5$ & 13 & $129 \cdot 7$ & 79 & $22 \cdot 07$ & 14 & $117 \cdot 6$ & 104 & $24 \cdot 71$ & $-12 \cdot 0$ \\
\hline $4 \cdot 1$ & 29 & $124 \cdot 0$ & 84 & $23 \cdot 28$ & 30 & $114 \cdot 0$ & 102 & $25 \cdot 20$ & $-8 \cdot 3$ \\
\hline \multirow{2}{*}{$3 \cdot 6$} & 7 & $123 \cdot 3$ & $9 \tilde{3}$ & $23 \cdot 77$ & 8 & $129 \cdot 0$ & 104 & $23 \cdot 17$ & $+2 \cdot 4$ \\
\hline & 28 & $120 \cdot 4$ & 85 & $22 \cdot 16$ & 24 & $111 \cdot 2$ & 81 & $25 \cdot 44$ & $-14 \cdot 8$ \\
\hline $3 \cdot 4$ & 15 & $131: 1$ & 87 & $22 \cdot 69$ & 16 & 113.3 & 88 & $28 \cdot 15$ & $-15 \cdot 2$ \\
\hline $3 \cdot 3$ & .. & .. & .. & .. & .. & .. & .. & .. & .. \\
\hline \multirow{2}{*}{$3 \cdot 0$} & 9 & $126 \cdot 8$ & 92 & $23 \cdot 90$ & 10 & $121 \cdot 1$ & 92 & $25 \cdot 09$ & $-5 \cdot 0$ \\
\hline & 131 & $131 \cdot 1$ & 91 & $23 \cdot 70$ & 32 & $121 \cdot 8$ & 92 & $25 \cdot 46$ & $-7 \cdot 4$ \\
\hline $2 \cdot 9$ & 17 & $123 \cdot 3$ & 88 & $24 \cdot 58$ & 18 & $124 \cdot 7$ & 102 & $25 \cdot 24$ & $-2 \cdot 8$ \\
\hline $2 \cdot 8$ & 25 & $123 \cdot 3$ & 98 & $23 \cdot 88$ & 26 & $112 \cdot 6$ & 94 & $25 \cdot 53$ & -6.9 \\
\hline \multirow{2}{*}{$2 \cdot 7$} & 11 & $122 \cdot 6$ & 90 & $24 \cdot 69$ & 12 & $126 \cdot 8$ & 107 & $24 \cdot 23$ & $+1 \cdot 9$ \\
\hline & 19 & $121 \cdot 8$ & 112 & $25 \cdot 24$ & 20 & $107 \cdot 6$ & 115 & $27 \cdot 93$ & $-10 \cdot 7$ \\
\hline $2 \cdot 5$ & .. & .. & .. & .. & .. & .. & .. & .. & .. \\
\hline $1 \cdot 8$ & .. & .. & .. & .. & .. & .. & .. & .. & .. \\
\hline $1 \cdot 5$ & .. & .. & .. & .. & .. & .. & .. & .. & .. \\
\hline $1 \cdot 3$ & -. & .. & .. & •. & $\cdot$ & .. & . & $\cdot \cdot$ & ・. \\
\hline
\end{tabular}


per pound of wood, and in the compound engine $3.82 \mathrm{lbs}$., we find for the compound engine, as compared with the ordinary, the following economy in consumption of fuel :-

with $4 \cdot 8$ times expansion 32 per cent.

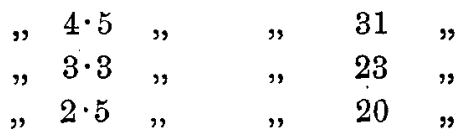

The examination of all these data leads therefore to the following conclusions:-

(1) With the same expansion of steam, the consumption of water and fuel per indicated horse-power is less in the compound than in the ordinary locomotive.

(2) The economy of water and fuel in the compound locomotive, under the same conditions of expansion, is greater according as the range of expansion is higher.

(3) With 4.8 times expansion, the highest that could be obtained in the ordinary locomotive A 22, the compound engine gave an economy of 22 per cent. in steam and of 32 per cent. in fuel.

Comparative Work done by Compound and Ordinary locomotives with equal consumption of water and fuel.

In order to be able to compare the work done by the same two engines on an equal consumption of water and fuel, a series of tests must be selected that were made with the same average boiler-pressure and the same mean number of revolutions per minute. In Table 11 are given the results of tests in which the pressures and speeds were nearly equal.

Analysing the data contained in this Table in a similar manner to the preceding Table 10, it is found:-

(1) For an equal consumption of $5247 \mathrm{lbs}$. of water per hour, the compound engine developed 222 horse-power, or 19 per cent. more than the ordinary engine A 22, which developed 187 horse-power.

(2) For an equal consumption of 5593 lbs. of water per hour, the difference in the work developed was 11 per cent. in favour of the compound engine. 
TABLE 11.

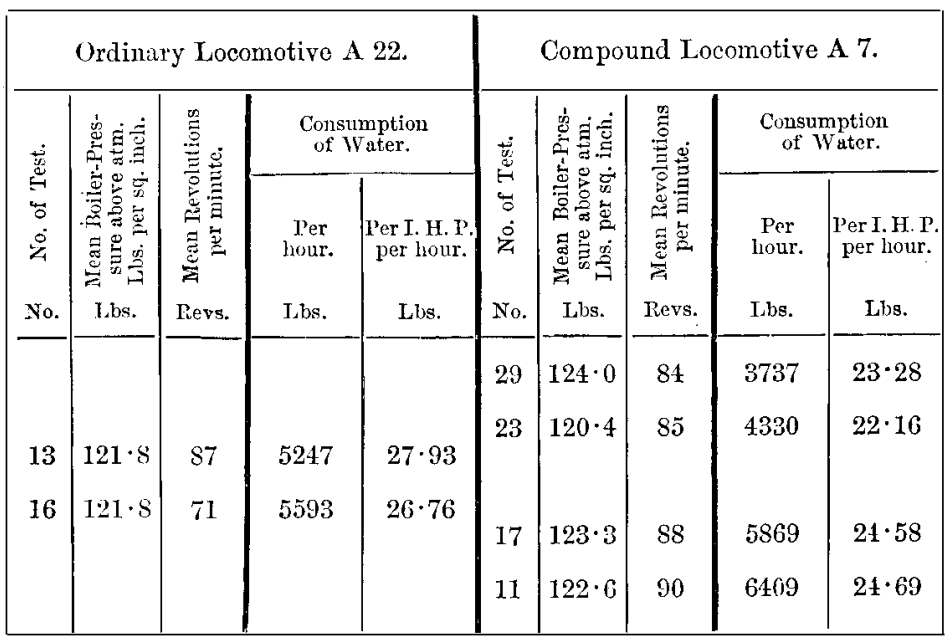

(3) For an equal consumption of $\frac{5247}{3 \cdot 33}=1574 \mathrm{lbs}$. of wood per hour, the compound engine developed 246 horse-power, or 32 per cent. more than the ordinary engine A 22, which developed 187 horsepower.

(4) For a consumption of $\frac{5593}{3 \cdot 33}=1678 \mathrm{lbs}$. of wood per hour, the difference was still 24 per cent. in favour of the compound.

We therefore arrive at the following conclusions :-

(1) For the same consumption of water and fuel per hour, the work done by the compound engine is greater than that done by the ordinary engine.

(2) For the same boiler-pressure and the same speed, the increase of work done by the compound engine compared with the ordinary engine diminishes in proportion as the total consumption of water and fuel per hour increases.

(3) For an equal consumption of $5247 \mathrm{lbs}$. of water per hour, with a boiler-pressure of 122 lbs. above atmosphere, and a speed of 87 revolutions per minute, the work done by the compound engine is 19 per cent. greater than that done by the ordinary engine. 
(4) Under the same conditions, and for an equal consumption of 1574 lbs. of wood per hour, the work done by the compound engine is 32 per cent. greater than that done by the ordinary engine.

Comparative Consumption of Water and Fuel

in Compound and Ordinary locomotives doing equal work.

The same tests may be taken for comparing the consumption of water and fuel in doing the same amount of work. All the necessary data from these tests are given in Table 12.

TABLE 12.

\begin{tabular}{|c|c|c|c|c|c|c|c|c|c|}
\hline \multicolumn{5}{|c|}{ Ordinary Locomotive A 22.} & \multicolumn{5}{|c|}{ Compound Locomotive A 7.} \\
\hline 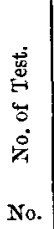 & 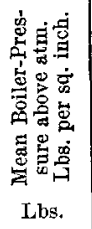 & 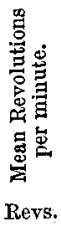 & $\begin{array}{c}\text { Mean } \\
\text { Indicated } \\
\text { Horse- } \\
\text { power. } \\
\text { I.H.P. }\end{array}$ & $\begin{array}{c}\text { Water } \\
\text { consumed } \\
\text { per I.H.P. } \\
\text { per hour. } \\
\text { Lbs. }\end{array}$ & 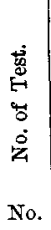 & 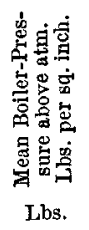 & 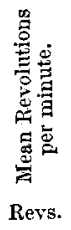 & $\begin{array}{c}\text { Mean } \\
\text { Indicated } \\
\text { Horse- } \\
\text { power. } \\
\text { I.II.P. }\end{array}$ & $\begin{array}{c}\text { Water } \\
\text { consumed } \\
\text { per I.H.P. } \\
\text { per hour. } \\
\text { Lbs. }\end{array}$ \\
\hline 16 & $121 \cdot 8$ & 87 & 187 & $\begin{array}{l}27 \cdot 93 \\
26 \cdot 76\end{array}$ & $\begin{array}{l}29 \\
23 \\
\\
17 \\
11\end{array}$ & $\begin{array}{l}120 \cdot 4 \\
123 \cdot 3 \\
122 \cdot 6\end{array}$ & $\begin{array}{l}88 \\
90\end{array}$ & $\begin{array}{l}239 \\
259\end{array}$ & $\begin{array}{l}24 \cdot 58 \\
24 \cdot 69\end{array}$ \\
\hline
\end{tabular}

As it is impossible to make a direct comparison of the figures in this Table, a curve has here again to be drawn, as represented in Fig. 35, Plate 73, showing for the compound engine how the consumption of water per indicated horse-power per hour varies with the quantity of work done at the same boiler-pressure of about $122 \mathrm{lbs}$. above atmosphere in this instance, and at the same speed of about 87 revolutions per minute. Test No. 13 of the ordinary engine A 22 is the only one which allows an accurate comparison to be made with the tests of the compound engine. Test No. 16, made 
with a smaller number of revolutions per minute than the preceding test, can furnish only approximate results.

From the curve in Fig. 35, Plate 73, it is found that the compound engine, when indicating 187 horse-power, consumes under the above conditions $22 \cdot 71$ lbs. of water per horse-power per hour. For the same work the ordinary engine A 22 consumes 27.93 lbs. per horse-power per hour, thus showing an economy of 19 per cent. in favour of the compound engine. Similarly when developing 209 horse-power the economy in consumption of water is 13 per cent. in favour of the compound engine.

The economy in consumption of fuel at 187 horse-power is 29 per cent., and at 209 horse-power 24 per cent. From this we conclude :-

(1) For doing the same work the compound engine uses less water and less fuel than the ordinary engine.

(2) At the same boiler-pressure and the same speed, the economy diminishes with the increase of work done.

(3) With a boiler-pressure of about $122 \mathrm{lbs}$. above atmosphere, and a mean speed of 87 revolutions per minute, and when developing 187 horse-power, the compound engine gives an economy over the ordinary engine of 19 per cent. in consumption of water and 29 per cent. in fuel.

\section{Proportion of Work done in Small and Large Cylinder of Compound locomotive.}

In describing the calculations of the work done by the engines, it has been explained that, for each test, curves were plotted for showing approximately how the mean cylinder-pressure varied with the number of revolutions per minute. From these curves has been calculated the work done separately by each cylinder of the compound engine at boiler-pressures of 113, 120, and $127 \mathrm{lbs}$. per square inch above atmosphere, and at speeds of 50, 100, and 150 revolutions per minute. In this way for each test the relation has been calculated between the work done in the small and the large cylinder separately. The values of these ratios are given in Table 13, page 342 . 


\section{TABLE 13.}

Work done in Small and Large Cylinder of Compound Locomotive.

\begin{tabular}{|c|c|c|c|c|c|c|c|c|c|c|c|c|}
\hline \multicolumn{2}{|c|}{$\begin{array}{l}\text { Cut-off. } \\
\text { Per cent. }\end{array}$} & \multirow{5}{*}{ 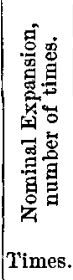 } & \multirow{5}{*}{ 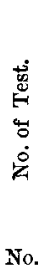 } & \multicolumn{9}{|c|}{$\begin{array}{l}\text { Ratio of Work done in Small cylinder, } \\
\text { to Work done in Large cylinder taken as unity. }\end{array}$} \\
\hline \multirow{4}{*}{ 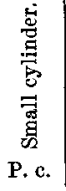 } & \multirow{4}{*}{ 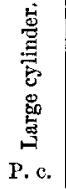 } & & & \multicolumn{6}{|c|}{ Boiler Pressure above atmosphere. } & \multicolumn{3}{|c|}{ Lbs. per square inch. } \\
\hline & & & & \multicolumn{3}{|c|}{113 lbs. } & \multicolumn{3}{|c|}{$120 \mathrm{lbs}}$. & \multicolumn{3}{|c|}{$127 \mathrm{lbs}}$. \\
\hline & & & & \multicolumn{3}{|c|}{ Revs. per minute. } & \multicolumn{3}{|c|}{ Revs. per minute. } & \multicolumn{3}{|c|}{ Revs. per minute. } \\
\hline & & & & 50 & 100 & 150 & 50 & 100 & 150 & 50 & 100 & 150 \\
\hline $45 \cdot 5$ & $67 \cdot 2$ & $4 \cdot 5$ & 13 & $1 \cdot 41$ & $1 \cdot 40$ & $1 \cdot 37$ & $1 \cdot 31$ & $1 \cdot 28$ & $1 \cdot 25$ & $1 \cdot 22$ & $1 \cdot 18$ & $1 \cdot 14$ \\
\hline " & ", & $"$ & I4 & 0.96 & $I \cdot I 8$ & $I \cdot I I$ & $0.9 \mathrm{I}$ & $I \cdot 09$ & $I \cdot$ & 0.89 & $I \cdot 05$ & $0.9 \mathrm{I}$ \\
\hline $60 \cdot 6$ & $"$ & $3 \cdot 4$ & 15 & $0 \cdot 98$ & $0 \cdot 93$ & $0 \cdot 91$ & $0 \cdot 96$ & 0.87 & 0.83 & 0.91 & 0.85 & $0 \cdot 79$ \\
\hline " & " & " & 16 & 0.83 & 0.75 & - & $0.8 \mathrm{I}$ & $0.7^{2}$ & - & 0.78 & 0.70 & 一 \\
\hline $70 \cdot 5$ & , & $2 \cdot 9$ & 17 & 0.72 & 0.72 & 0.67 & $0 \cdot 70$ & $0 \cdot 71$ & $0 \cdot 64$ & 0.69 & 0.67 & $0 \cdot 61$ \\
\hline " & $"$ & $"$ & 18 & 7 이 & 0.70 & 0.53 & 0.67 & 0.62 & $0.5 \mathrm{I}$ & 0.67 & 0.59 & 0.50 \\
\hline $76 \cdot 9$ & ", & $2 \cdot 7$ & 19 & 0.56 & 0.53 & 0.49 & 0.55 & 0.52 & 0.47 & 0.54 & $0 \cdot \tilde{51}$ & 0.45 \\
\hline$"$ & , & " & 20 & 55 & 0.47 & $0.4 \pi$ & 0.53 & 0.45 & 0.39 & 0.53 & 0.45 & 0.38 \\
\hline $40 \cdot 9$ & 64.9 & 5.0 & 5 & $1 \cdot 29$ & $1 \cdot 47$ & $1 \cdot 31$ & $\cdot 19$ & $1 \cdot 37$ & $1 \cdot 17$ & -15 & $1 \cdot 26$ & $\cdot 17$ \\
\hline$"$ & " & " & 6 & 9 & $I \cdot I 3$ & $I \cdot 43$ & 94 & $I \cdot 0.4$ & $I \cdot 27$ & $0.9 \mathrm{I}$ & 0.96 & $I \cdot I 9$ \\
\hline $57 \cdot 1$ & " & $3 \cdot 6$ & 7 & $0 \cdot 94$ & 0.98 & 0.54 & 89 & 0.92 & 0.54 & 0.85 & 0.89 & 0.48 \\
\hline$"$ & $"$ & $"$ & 8 & 0.85 & 0.80 & 0.77 & 0.83 & 0.78 & 0.73 & 0.78 & 0.74 & 0.73 \\
\hline $68 \cdot 3$ & $"$ & $3 \cdot 0$ & 9 & $0 \cdot 68$ & 0.65 & $0: 56$ & 0.67 & 0.62 & 0.53 & 0.66 & 0.61 & $0 \cdot 50$ \\
\hline$"$ & $"$ & $"$ & IO & 0.70 & 0.66 & 0.38 & 0.67 & 0.57 & 0.36 & 0.65 & 0.54 & 0.35 \\
\hline $75 \cdot 2$ & " & $2 \cdot 7$ & 11 & 0.61 & 0.49 & $0 \cdot 34$ & 0.57 & $0 \cdot 48$ & $0 \cdot 3$ & 0.59 & 0.47 & $0 \cdot 32$ \\
\hline , & $"$ & ", & 12 & 0.53 & $0.5 \mathrm{r}$ & 0.44 & $5 \mathrm{I}$ & 0.49 & 0.43 & 0.51 & 0.47 & $0.4 \mathrm{I}$ \\
\hline $30 \cdot 5$ & $57 \cdot 8$ & $6 \cdot 7$ & 21 & $1 \cdot 49$ & $1 \cdot 50$ & $2 \cdot 07$ & $\mathbf{1} \cdot 42$ & $1 \cdot 32$ & $1 \cdot 74$ & $1 \cdot 24$ & $1 \cdot 32$ & $1 \cdot 55$ \\
\hline$"$ & $"$ & $"$ & 22 & 13 & $r \cdot r 9$ & 41 & 1.08 & $\mathrm{I} .06$ & $x * 15$ & $\mid r .03$ & I.0I & 0.98 \\
\hline $56 \cdot 3$ & $"$ & $3 \cdot 6$ & 23 & $0 \cdot 85$ & $0 \cdot 71$ & $0 \cdot 51$ & 0.81 & $0 \cdot 67$ & 0.49 & $0 \cdot 77$ & 0.64 & 0.46 \\
\hline$"$ & ", & $"$ & 24 & 0.63 & 0.55 & - & 0.62 & 0.52 & 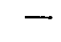 & 0.68 & 0.50 & - \\
\hline $73 \cdot 3$ & $"$ & $2 \cdot 8$ & 25 & 0.56 & 0.47 & $0 \cdot 37$ & 0.54 & $0 \cdot 45$ & $0 \cdot 35$ & 0.54 & 0.45 & $0 \cdot 34$ \\
\hline$"$ & $"$ & $"$ & 26 & 0.49 & 0.37 & 0.32 & $0.4^{8}$ & 0.35 & 0.31 & $0^{\circ} 4^{8}$ & 0.35 & 0.29 \\
\hline $49 \cdot 5$ & $49 \cdot 8$ & $4 \cdot 1$ & 29 & 0.87 & $0 \cdot 71$ & 0.53 & 0.82 & 0.68 & 0.49 & 0.77 & $0 \cdot 64$ & 0.45 \\
\hline$"$ & $"$ & $"$ & 30 & 0.75 & 0.60 & 0.47 & $0.7 x$ & 0.56 & 0.43 & 0.68 & 0.53 & 0.45 \\
\hline $69 \cdot 2$ & $"$ & $3 \cdot 0$ & 31 & $0 \cdot 45$ & $0 \cdot 39$ & - & 0.43 & $0 \cdot 38$ & - & 0.43 & 0.35 & - \\
\hline$"$ & $"$ & $"$ & 32 & $0.5 \mathrm{I}$ & 0.36 & - & 0.49 & 0.36 & - & 0.47 & 0.35 & 一 \\
\hline
\end{tabular}


An examination of the figures in this Table 13 shows:-

(1) For the same boiler-pressure and the same number of revolutions, the proportion of work done in the small and the large cylinder varies according to the cut-off in the respective cylinders.

(2) For the same boiler-pressure, the same number of revolutions, and the same cut-off in the large cylinder, the proportionate work done in the small cylinder decreases as the admission into the small cylinder increases.

The proportion of work done in the small and the large cylinder varies with the speed when the boiler-pressure remains the same, and with the pressure when the speed remains the same.

It is therefore altogether impossible to arrive at any fixed combinations of cut-off in the two cylinders whereby the work developed shall be equalised in both cylinders for all speeds and all pressures that occur in running.

\section{Effect of Jackets on Consumption of Steam.}

In Table 10 , pages $336-7$, is given the ascertained consumption of steam per indicated horse-power per hour for the tests with and without jackets, including the steam used in the jackets themselves.

Comparing the consumption of water per indicated horse-power per hour with and without jackets, in the tests made with equal degrees of expansion, the economy produced by the jackets has been calculated in corresponding columns in Table 10, where the plus sign + shows an economy in favour of the jackets, and the minus sign - an increase in consumption of steam when the jackets were used.

The examination of these columns shows for the ordinary engine A 22, when working with the highest expansion of 4.8 times in the first notch, an economy of 12 per cent. in favour of the jackets. With 3.3 times expansion in the second notch, the effect of the jackets disappears; with $2 \cdot 5$ times expansion, the economy from the use of the jackets is 3 per cent.; and for lower degrees of expansion it gradually decreases to nothing, and even becomes negative when the expansion is only $1 \cdot 3$ times.

The entire failure of the attempts to measure the quantity of water condensed in the jackets, as well as the impossibility of 
selecting an average diagram representing with sufficient accuracy the mean work of the steam in the cylinders during the whole of the test, rendered it hopeless to estimate the effect which the jackets had upon the condition of the steam in the cylinders.

In order to avoid loss of steam through the apparatus for draining the jackets, it was necessary to open the cock but slightly; and thus an imperfect discharge of the condensed water may have been the result.

It must be noted however that in these tests the effect of the steam-jackets is much less than in those carried out in the testing shed. To a certain extent this may be explained by the expenditure of steam at each opening of the regulator for warming the jackets, and by the unprofitable condensation of the steam remaining in them at each closing of the regulator; these losses did not take place during the experiments made in the testing shed. Also the probably imperfect draining of the jackets would not be without influence on their effect.

Passing on to the tests of the compound engine in Table 10, it must be observed in the first place that the consumption of steam in the tests made when the jackets were at work must up to a certain point be greater than in the tests made when they were not at work, in consequence of the higher mean speed of running when the jackets were working. Nevertheless the negative results given by the jackets cannot be disputed. This altogether unexpected result may to a certain extent be explained by peculiarities in the construction of the compound engine, and by the conditions under which it worked.

Foremost must be noted the advantageous position of the intermediate receiver placed inside the hot smoke-box, where the temperature rises to $570^{\circ} \mathrm{Frhr}$. and upwards. The steam in its passage from the small to the large cylinder thus encounters a new and abundant source of heat, and is heated up to a certain point (perhaps even superheated), and in this state enters the large cylinder to continue its work. The compound locomotive therefore works under more advantageous conditions than a compound stationary engine, in which the intermediate receiver is not heated 
or is only a little herted; consequently the useful effect of the jackets should be less in a compound locomotive than in a compound stationary ongine.

Moreover in a compound locomotive with steam-jacketed cylinders, like the compound A 7, the loss of steam in heating the cylinders and jackets at each opening and closing of the regulator will be greater than in an oxdinary locomotive, owing to the large volume of the cylinders and jackets; but as the consumption of steam per horsepower per hour is less in the compound locomotive, it follows that the expenditure of steam for working the jackets in the compound engine is relatively greater than in an ordinary locomotive. These circumstances, to which must be added the probably imperfect draining of the condensed water, have led to the negative results given by the jackets of the compound engine.

\section{Experiments made in 1881-82}

with Compound and Ordinary locomotives while running.

Prior to the tests already described, and soon after the first engine had been altered to the compound system in 1881-82, a number of experimental runs were made with the ordinary engine A 22 and the compound A 7. These runs were made during the ordinary working of these engines when taking the mail trains between Kieff, Fastoff, and Kasatine, a distance of 97 miles. During the trip the engine worked with different degrees of cut-off in the cylinders; and the compound engine at starting made a few revolutions with boiler steam admitted direct into both cylinders.

The method adopted in these tests did not differ at all from that employed in the tests subsequently carried out with the same engines in 1883, pages 324-328. The results obtained are grouped together in Table 14 on page 346 .

The following approximate conclusions are arrived at from this Table :-

(1) When the jackets are not in use, the compound engine gives in comparison with the ordinary engine an economy of 13 per cent. in consumption of steam, and of 24 per cent. in consumption of wood. 
TABLE 14.

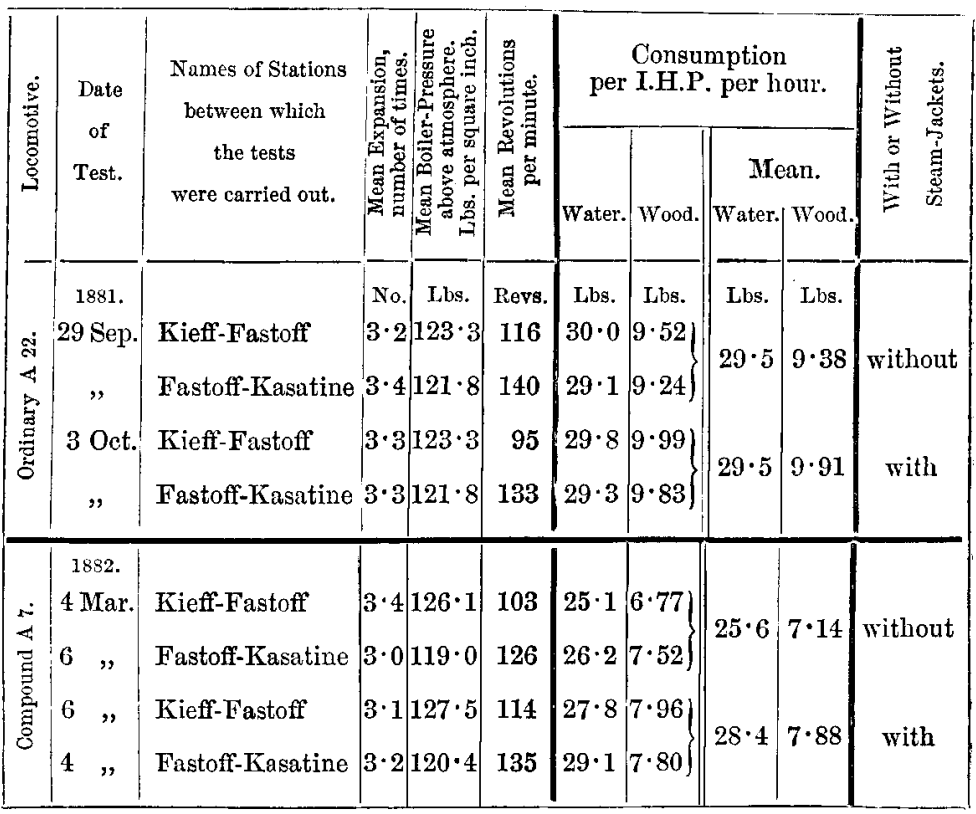

(2) Admission of steam into the jackets does not sensibly affect the consumption of steam in the ordinary engine; whilst in the compound engine it produces an injurious effect, increasing the consumption of water and wood per indicated horse-power.

These conclusions accordingly agree with those derived from the tests subsequently carried out in 1883 and already described in the foregoing pages $324-345$. 
PART III.-Consumption of Fueit In Compound locomotive,

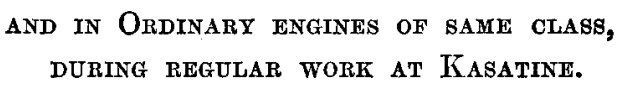

The ordinary work of a locomotive in service depends on such a number of different circumstances, which occur on the road and are of a nature to produce disturbing influences, that it is very difficult or almost impossible to arrive at any accurate conclusion concerning the result of the ordinary work done by the engines when running. Nevertheless, after five years' regular work of the compound engine A 7, it is interesting to compare the data thus obtained as to the consumption of fuel in this engine and in the other ordinary engines of the same class A, during their work at Kasatine under conditions more or less identical.

This comparison shows that, during the period 1881-1885 inclusive, the mean consumption of wood was as given in Table 15:-

TABLE 15. Mean Consumption of Wood during five years.

\begin{tabular}{|c|c|c|c|}
\hline & $\begin{array}{c}\text { By the } \\
\text { Ordinary } \\
\text { engines } \\
\text { of class A. }\end{array}$ & $\begin{array}{c}\text { By the } \\
\text { Compound } \\
\text { engine } \\
\text { A 7. }\end{array}$ & $\begin{array}{c}\text { Economy! } \\
\text { in favour of } \\
\text { Compound } \\
\text { engine. }\end{array}$ \\
\cline { 2 - 4 } Per 1000 engine-miles & $\begin{array}{c}\text { Cubic Feet. } \\
2649\end{array}$ & $\begin{array}{c}\text { Cubic Feet. } \\
2244\end{array}$ & $\begin{array}{c}\text { Per cent. } \\
15\end{array}$ \\
$\begin{array}{c}\text { Per 1000 axle-miles } \\
\text { run by wagons }\end{array}$
\end{tabular}

Thus according to the returns the economy shown by the compound engine in consumption of fuel during the five years 1881-1885 ranges between 15 and 25 per cent. It may be added that the returns also show that the compound engine worked during each year more economically than any other engine of the same class at Kasatine. 
TABLE 16. Consumption of Steam

in Ordinary and Compound Locomotives without Steam-Jackets.

\begin{tabular}{|c|c|c|c|c|c|c|c|c|}
\hline \multicolumn{6}{|c|}{ Ordinary Locomotives A 21 and A 22.} & \multicolumn{3}{|c|}{ Compound Locomotive A 7 . } \\
\hline \multicolumn{3}{|c|}{$\begin{array}{l}\text { Reversing Lever } \\
\text { in second notch. } \\
\text { Nominal Expansion } \mathbf{3} \cdot \mathbf{3} \text { times. }\end{array}$} & \multicolumn{3}{|c|}{$\begin{array}{c}\text { Reversing Lever } \\
\text { in first notch. } \\
\text { Nominal Expansion } 4 \cdot 5 \text { to } 5 \cdot 0 \text { times. }\end{array}$} & \multicolumn{3}{|c|}{$\begin{array}{l}\text { Reversing Lever :- } \\
\text { Small cyl. first notch. Large cyl. } 60^{\circ} \text {. } \\
\text { Nominal Expansion } 6.7 \text { times. }\end{array}$} \\
\hline 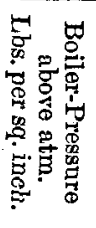 & $\begin{array}{c}\text { Consumption } \\
\text { of Steam } \\
\text { per I. H. P. } \\
\text { per hour. }\end{array}$ & $\begin{array}{c}\text { Experimental } \\
\text { Train, } \\
\text { or Testing Shed. } \\
\text { Year.* } \\
\text { Engine } \\
\text { A } 21 \text { or A } 22 .\end{array}$ & 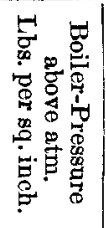 & $\begin{array}{l}\text { Consumption } \\
\text { of Steam } \\
\text { per I. H. P. } \\
\text { per hour. }\end{array}$ & $\begin{array}{c}\text { Experimental } \\
\text { Train, } \\
\text { or Testing Shed. } \\
\text { Year.* } \\
\text { Engine } \\
\text { A } 21 \text { or A } 22 .\end{array}$ & 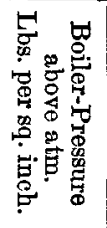 & $\begin{array}{c}\text { Consumption } \\
\text { of Steam } \\
\text { per I. H. P. } \\
\text { per hour. }\end{array}$ & $\begin{array}{l}\text { Experimental } \\
\text { Train, } \\
\text { or } \\
\text { Testing Shed. } \\
\text { Year. } †\end{array}$ \\
\hline $\begin{array}{l}\text { Lbs. } \\
121 \cdot 8 \\
79 \cdot 8 \\
62 \cdot 3 \\
60 \cdot 6 \\
56 \cdot 0 \\
55 \cdot 3 \\
55 \cdot 4\end{array}$ & $\begin{array}{l}\text { Lbs. } \\
26 \cdot 76 \\
29 \cdot 85 \\
32 \cdot 14 \\
31 \cdot 86 \\
30 \cdot 97 \\
31 \cdot 61 \\
31 \cdot 61\end{array}$ & \multirow[t]{2}{*}{$\begin{array}{l}\text { Train 1883. A } 22 \\
\text { Shed 1881. A } 21 \\
\text { Shed 1882. A } 22\end{array}$} & \begin{tabular}{r|} 
Lbs. \\
$127 \cdot 5$ \\
$121 \cdot 8$ \\
$91 \cdot 4$ \\
$76 \cdot 4$ \\
$76 \cdot 7$ \\
$75 \cdot 0$ \\
$75 \cdot 6$
\end{tabular} & $\left.\begin{array}{r}\left.\begin{array}{r}\text { Lbs. } \\
28 \cdot 11 \\
27 \cdot 93\end{array}\right\} \\
30 \cdot 36 \\
31 \cdot 20 \\
31 \cdot 90 \\
31 \cdot 86 \\
33 \cdot 69\end{array}\right\}$ & $\begin{array}{l}\text { Train 1883. A } 22 \\
\text { Shed 1881. A } 21 \\
\text { Shed 1882. A } 22\end{array}$ & $\begin{array}{r}\text { Lbs. } \\
127 \cdot 5 \\
99 \cdot 2 \\
97 \cdot 3\end{array}$ & $\begin{array}{r}\left.\begin{array}{r}\text { Ibs. } \\
19 \cdot 95 \\
24 \cdot 67 \\
25 \cdot 18\end{array}\right\}\end{array}$ & $\begin{array}{l}\text { Train } 1883 . \\
\text { Shed } 1881 .\end{array}$ \\
\hline $\begin{array}{l}54 \cdot 4 \\
52 \cdot 3 \\
51 \cdot 6 \\
51 \cdot 3 \\
50 \cdot 6 \\
45 \cdot 0 \\
\end{array}$ & $\left.\begin{array}{l}33 \cdot 20 \\
32 \cdot 72 \\
33 \cdot 40 \\
\mathbf{3 4} \cdot 33 \\
\mathbf{3 4} \cdot 97 \\
35 \cdot 03\end{array}\right)$ & & \multicolumn{3}{|c|}{$\begin{array}{c}\text { * For tests in } 1881 \text { see Tables } 5 \text { and } 6 . \\
\quad " \quad 1882 \text { ", Table } 2 . \\
" \quad \\
1883 \text { "Table } 9 .\end{array}$} & \multicolumn{3}{|c|}{$\begin{array}{c}\text { † For tests in } 1881 \text { see Table } 7 . \\
" \quad 1883 \text { " Table } 9 .\end{array}$} \\
\hline
\end{tabular}




\section{PART IV.--Generat Conclusions.}

(1) Comparing the consumption of steam per horse-power, as arrived at by altogether different methods in the testing shed and when running with experimental trains, Table 16 is obtained, page 348 , for the working without steam-jackets and with the same degree of expansion.

As here seen, the results obtained from the trials made in the testing shed and with the experimental trains, by altogether different methods, during different years, and with different engines of the same class, agree with one another, and prove that the consumption of steam per horse-power in all the tests increases regularly as the boiler-pressure diminishes.

The results of the tests carried out with the jackets at work are not here referred to, because in the experimental trains, as already stated, the jackets did not work properly.

(2) Comparing the consumption of steam per indicated horscpower at different degrees of expansion, obtained with the ordinary engine A 22 when working without jackets in the experimental trains, as given in Table 9, the following Table 17 is compiled :-

TABLE 17. Ordinary Locomotive A 22 without Steam-Jackets.

\begin{tabular}{|c|r|c|}
\hline $\begin{array}{c}\text { Position of } \\
\text { Reversing Lever. } \\
\text { Notcl. }\end{array}$ & $\begin{array}{c}\text { Nominal } \\
\text { Expansion. } \\
\text { Times. }\end{array}$ & $\begin{array}{c}\text { Consumption } \\
\text { of Watter } \\
\text { per I. H.P. } \\
\text { per hour. } \\
\text { Lbs. }\end{array}$ \\
\hline 1 & 4.8 & $\begin{array}{r}27.93 \\
28.11 \\
26.76\end{array}$ \\
2 & 3.3 & 28.59 \\
3 & 2.5 & $31 \cdot 17$ \\
5 & 1.8 & 35.45 \\
7 & 1.5 & 40.37 \\
\hline
\end{tabular}


As here seen, the work done by the steam when running in the first notch is not only not more advantageous, but is even less economical than when working in the second notch with a lower expansion: this conclusion is confirmed by the results obtained in the testing shed in 1882 and 1881 (pages 315 and 321). The consumption per indicated horse-power in the third notch, expanding about $2 \cdot 5$ times, is hardly greater than when working in the first notch, expanding nearly 5 times. Thus the conclusion arrived at on page 321 is confirmed by all the tests, namely that it is disadvantageous to use cylinders of too large size. The work done in the seventh and eleventh notches, with 1.5 and 1.3 times expansion, is seen to be attended with very little economy; but it must not be forgotten that these latter tests were made with the regnlator only slightly open, whereby the free passage of the steam into the cylinders was obstructed (see page 331).

(3) In Table 18, page 351, is given a similar comparison of the consumption of steam in the compound engine at different degrees of expansion and without steam-jackets, the figures being compiled from Table 9.

For all the positions $\left(73^{\circ}, 70^{\circ}, 60^{\circ}\right.$, and $\left.50^{\circ}\right)$ of the reversing screw of the large cylinder, a regular though slow increase is observed in the consumption of steam per horse-power, according as the degree of expansion decreases between the limits of $6 \cdot 7$ and $2 \cdot 7$ times.* This difference from what took place with the ordinary engine A 22 is explained if it be remembered that in the compound engine the condensation of steam during admission is comparatively less, and consequently this condensation does not produce such a bad effect on the total consumption of steam at an early cut-off or high degree of expansion as it does in ordinary engines.

Comparing the consumption of steam at different positions of the reversing screw of the large cylinder, it is found that, with the same degree of expansion, the lowest consumption took place with the screw at $60^{\circ}$, corresponding with an admission into the large cylinder

* In the test in which the position of the reversing lever was $1-50^{\circ}$, it appears that the expansion was carried too far, namely $9 \cdot 1$ times. 
TABLE 18. Compound Locomotive without Steam-Jackets.

\begin{tabular}{|c|c|c|c|c|c|c|c|}
\hline \multicolumn{2}{|c|}{$\begin{array}{c}\text { Position of } \\
\text { Reversing Lever. }\end{array}$} & \multirow{2}{*}{$\begin{array}{l}\text { Nominal } \\
\text { Expansion, } \\
\text { numbar } \\
\text { of } \\
\text { times. }\end{array}$} & \multirow{2}{*}{$\begin{array}{c}\text { Steam } \\
\text { Consumption } \\
\text { per } \\
\text { indicated } \\
\text { horse-power } \\
\text { per bour. }\end{array}$} & \multicolumn{2}{|c|}{$\begin{array}{c}\text { Position of } \\
\text { Reversing Lever. }\end{array}$} & \multirow{2}{*}{$\begin{array}{c}\text { Nominal } \\
\text { Expansion } \\
\text { number } \\
\text { of } \\
\text { times. }\end{array}$} & \multirow{2}{*}{$\begin{array}{c}\text { Steam } \\
\text { Consumption } \\
\text { per } \\
\text { indicated } \\
\text { horse-power } \\
\text { per hour. }\end{array}$} \\
\hline $\begin{array}{c}\text { Small } \\
\text { cylinder. }\end{array}$ & $\begin{array}{c}\text { Large } \\
\text { cylinder. }\end{array}$ & & & $\begin{array}{c}\text { Sma!l } \\
\text { cylinder. }\end{array}$ & $\begin{array}{l}\text { Large } \\
\text { cylinder. }\end{array}$ & & \\
\hline Notch. & & Times. & Lbs. & Notch. & & Times. & Lbs. \\
\hline 1 & $73^{\circ}$ & $4 \cdot 5$ & $22 \cdot 07$ & 1 & $60^{\circ}$ & $6 \cdot 7$ & $19 \cdot 95$ \\
\hline 3 & $73^{\circ}$ & $3 \cdot 4$ & $22 \cdot 69$ & 4 & $60^{\circ}$ & $3 \cdot 6$ & $22 \cdot 16$ \\
\hline 5 & $73^{\circ}$ & $2 \cdot 9$ & $24 \cdot 58$ & 7 & $60^{\circ}$ & $2 \cdot 8$ & $23 \cdot 88$ \\
\hline 7 & $73^{\circ}$ & $2 \cdot 7$ & $25 \cdot 24$ & & & & \\
\hline 1 & $70^{\circ}$ & $5 \cdot 0$ & $22 \cdot 62$ & 1 & $50^{\circ}$ & $9 \cdot 1$ & $23 \cdot 68$ \\
\hline 3 & $70^{\circ}$ & $3 \cdot 6$ & $23 \cdot 77$ & 4 & $50^{\circ}$ & $4 \cdot 1$ & $23 \cdot 28$ \\
\hline 5 & $70^{\circ}$ & $3 \cdot 0$ & $23 \cdot 90$ & 7 & $50^{\circ}$ & $3 \cdot 0$ & $23 \cdot 70$ \\
\hline 7 & $70^{\circ}$ & $2 \cdot 7$ & $24 \cdot 69$ & & & & \\
\hline
\end{tabular}

during 58 per cent. of the stroke; this was observed at each position of the reversing lever of the small cylinder. This result might almost have been expected, taking into consideration the ratio of the volumes of the two cylinders, namely 1 to $2 \cdot 04$. In order therefore to work to the greatest advantage, the distribution of the steam should be so arrauged that the admission into the large cylinder may be constant, no matter what may be the position of the reversing lever of the small cylinder, and the admission into the large cylinder should depend upon the ratio of the volumes of the two cylinders.

It must be observed however that the variations in the admission into the large cylinder within the limits of $50^{\circ}$ and $70^{\circ}$ of the reversing screw, corresponding with admissions of from 50 to 67 per cent. of the stroke, have very little effect on the consumption of steam. But on the other band, if the admission into the large cylinder is less than 50 per cent. of the stroke, the expenditure of steam per horse-power increases perceptibly, and becomes greater as the admission into the 
large cylinder is less. This can be gathered from tests made in 1883 with the compound engine in the testing shed, which gave the results shown in Table 19.

TABLE 19. Compound Locomotive in Testing Shed 1883.

\begin{tabular}{|c|c|c|c|c|c|c|c|c|}
\hline 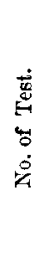 & 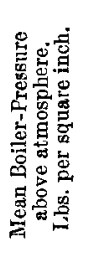 & 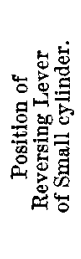 & 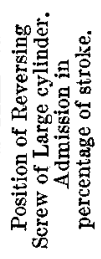 & 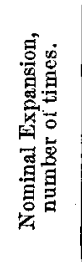 & 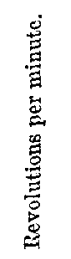 & 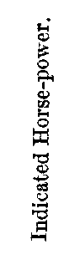 & 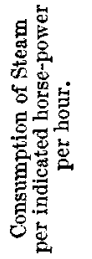 & 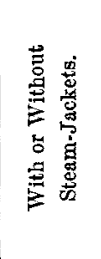 \\
\hline No. & Lbs. & Notch. & Per cent. & Times. & Rers. & I. H.P. & Lbs. & \\
\hline 33 & $135 \cdot 5$ & 2 & 40 & 9 & 82 & $68 \cdot 5$ & $29 \cdot 32$ & without \\
\hline 34 & $129 \cdot 9$ & 2 & 40 & 9 & 78 & $59 \cdot 8$ & $29 \cdot 63$ & without \\
\hline 35 & $129 \cdot 5$ & 2 & 40 & 9 & 68 & $51 \cdot 6$ & $26 \cdot 61$ & with \\
\hline 36 & $81 \cdot 4$ & 5 & 40 & 4 & 88 & $70 \cdot 1$ & $34 \cdot 04$ & with \\
\hline 37 & $86 \cdot 1$ & 5 & 40 & 4 & 93 & $84 \cdot 4$ & $31 \cdot 44$ & without \\
\hline 38 & $71 \cdot 6$ & 7 & 30 & $3 \cdot 4$ & 87 & $59 \cdot 2$ & $40 \cdot 52$ & without \\
\hline 39 & $69 \cdot 6$ & 7 & 30 & $8 \cdot 4$ & 79 & $56 \cdot 0$ & $38 \cdot 32$ & with \\
\hline
\end{tabular}

So low an economy in the working of the engine is explained on examining the diagrams from the small cylinder, particularly those taken when the admission into the large cylinder was small; they are very irregular in outline, owing to too much compression. These irregularities sometimes attain such a degree that the small cylinder is converted into a regular brake, producing negative work. As was to be expected, the results of these tests prove that it is disadrantageous to give the large cylinder a smaller admission than corresponds with the volume of the small cylinder.

(4) Turning to the question of the economy produced by the steam-jackets and by the compound system, the following conclusions are arrived at :- 
(a) The steam-jackets on the ordinary engine, while working in the testing shed in the first and second notches, undoubtedly gave a mean economy in steam consumption of 16 to 12 per cent. (see page 315). In the experimental trains the jackets did not generally give satisfactory results, except when the ordinary engine was working in the first notch (page 343); but this must be attributed partly to the loss of steam in warming up the walls of the jackets each timo the regulator was opened, and above all to the imperfect draining of the jackets (page 344), whereby they were probably converted into condensers. A better means of draining the steam-jackets must therefore be sought for.

(b) The compound system undoubtedly gave an economy of steam and of fuel; the amount of this economy varies perceptibly with the conditions under which the engine is working, and in ordinary work it may be taken at from 15 to 20 per cent.

The greater quantity of water evaporated per pound of wood in the tests with the compound locomotive cannot yet be attributed with certainty to the compound system : it may have resulted from individual peculiarities of the boiler and of the fireman, and also from lack of sufficient accuracy in estimating the consumption of wood. Nevertheless, inasmuch as the compound locomotive consumes less fuel for doing the same amount of work, it will consequently require less blast, and will less frequently need an injurious contraction of the blast-nozzle; whence it is possible to utilise the fuel better in the boiler of the compound engine.

Furthermore, the smaller consumption of steam in the compound locomotive allows of its taking heavier trains wherever there is already a surplus of tractive power as well as of adhesion. This is one of the important advantages of the compound system, which must not be lost sight of when judging of its value.

(5) Considering that the componnd locomotive with which the experiments were carried out involves scarcely any complication, and that it costs about the same to build as the ordinary engines, and that a decrease in consumption of fuel lessens the cost of boiler 
repairs and of providing feed-water \&c., it may be concluded that there is an undoubted advantage in building locomotives on the compound system.

In concluding this paper the author wishes once more to draw attention to the advantages of a testing shop, properly fitted up, for investigating all the conditions of the work done by locomotives and their boilers. An idea can be formed on this subject by comparing the methods described in Parts I and II of this paper, and by noticing that the methods of observation in the testing shop are simple and accurate, and present facilities for calculation and verification; while the others are difficult, minute, very complicated, incapable of verification, and dependent upon all sorts of eventualities that may happen while the train is running. That the author was obliged to have recourse to such complicated and difficult processes, whereby this work was extended over several years, was because of the primitive nature of his testing shed, and chiefly because he had no brake-dynamometer such as would have rendered it possible to carry out the tests under all desired conditions of pressure, expansion, speed, \&c. 


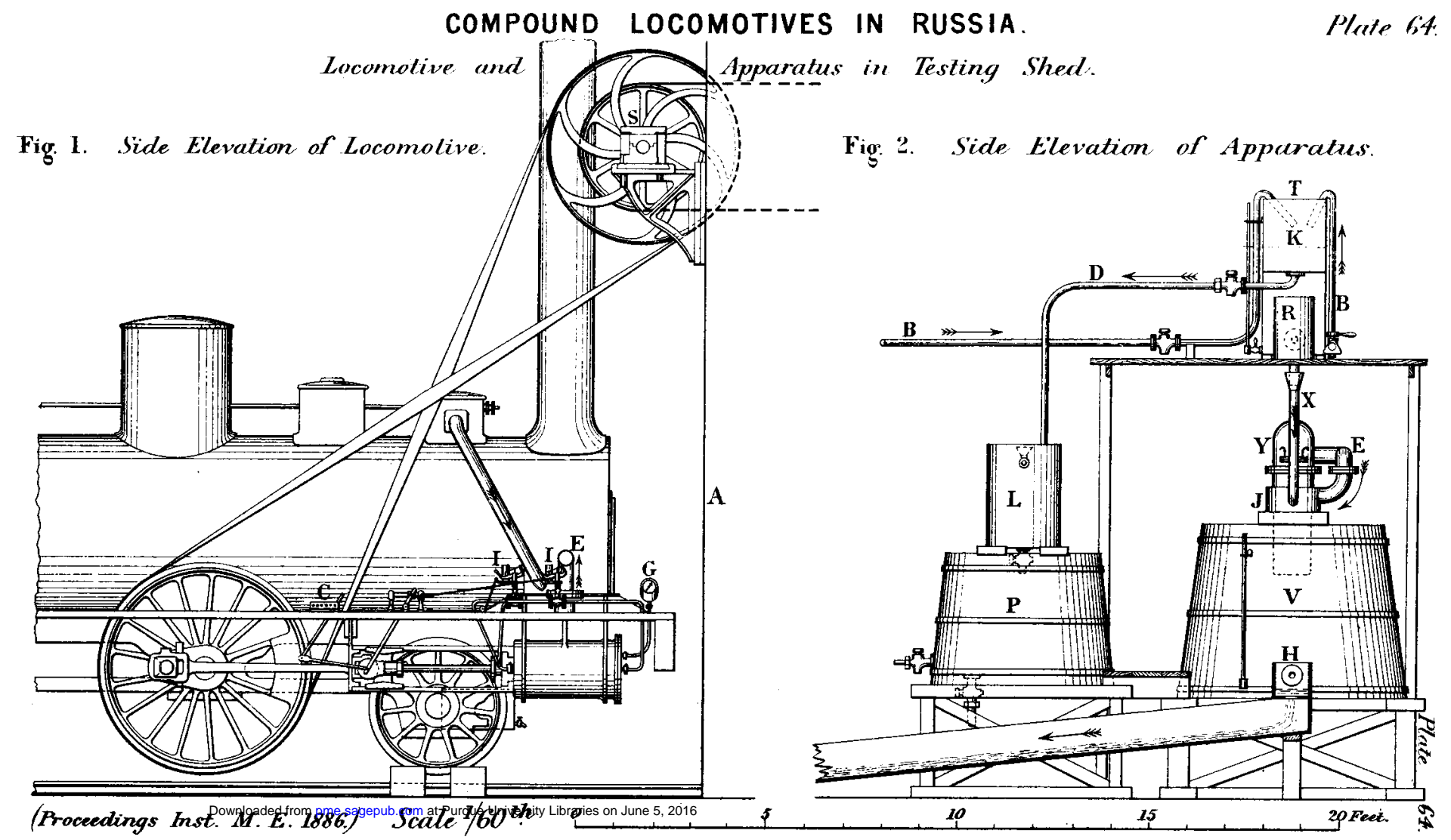




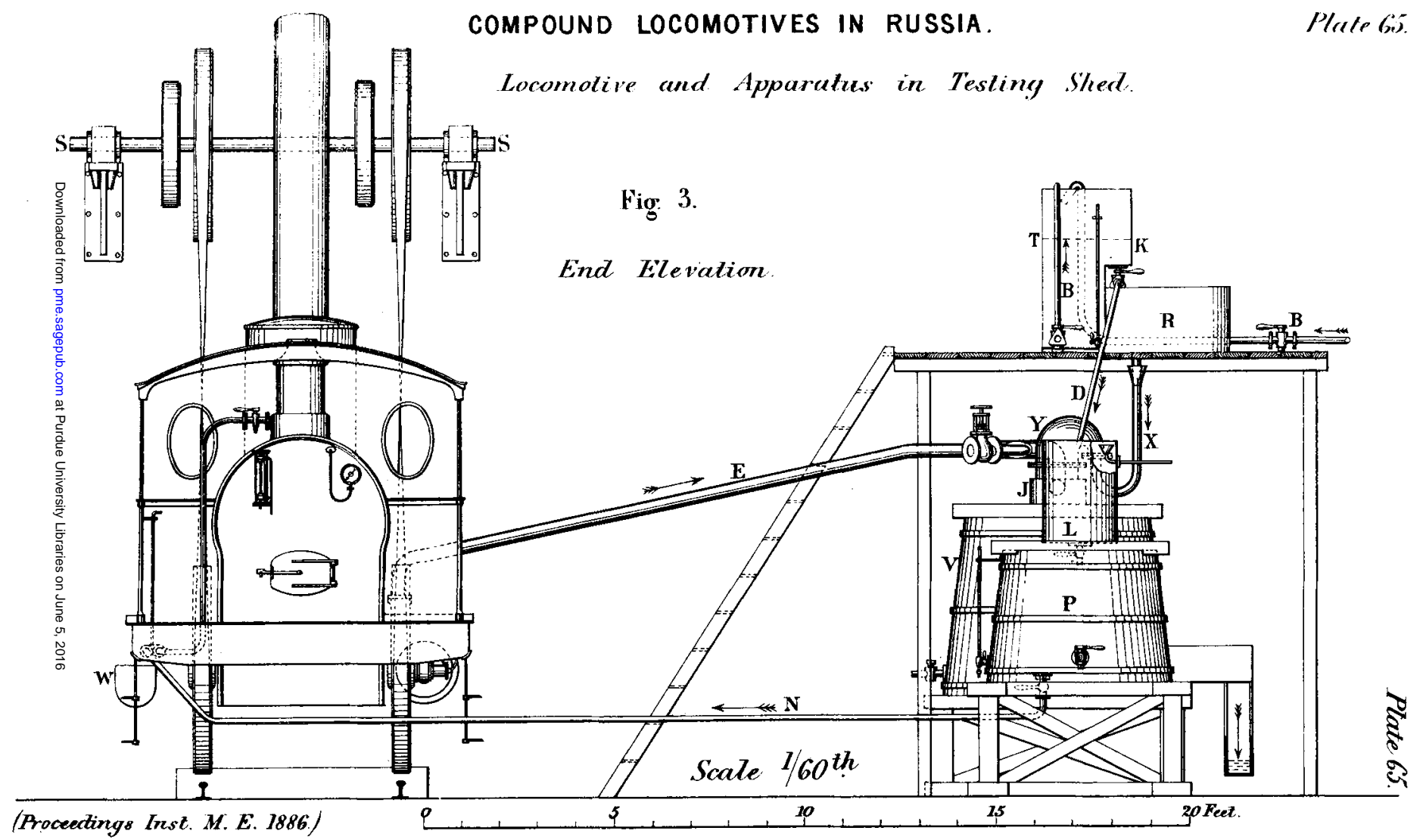


COMPOUND LOCOMOTIVES IN RUSSIA.

Ploce bis.

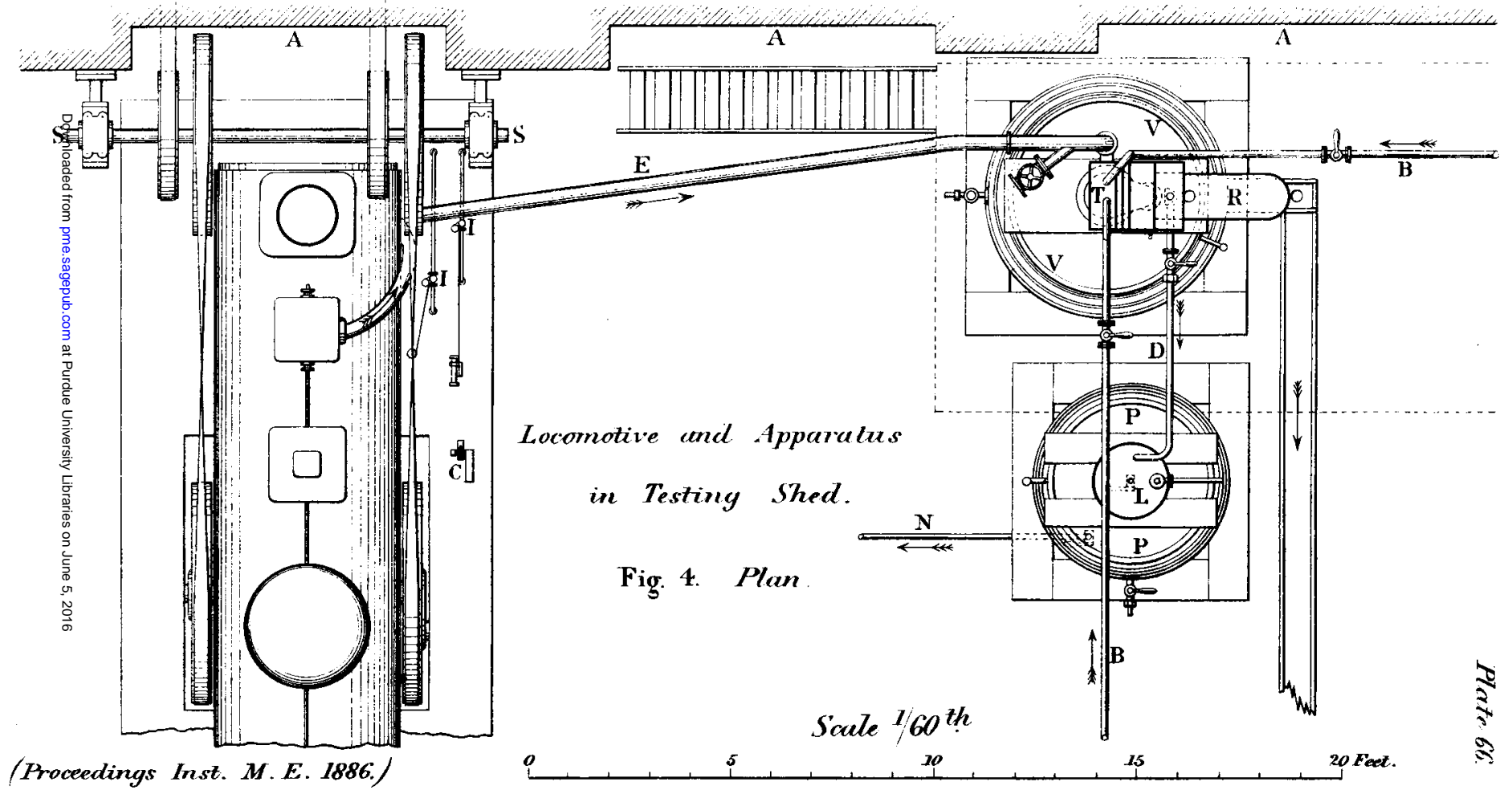




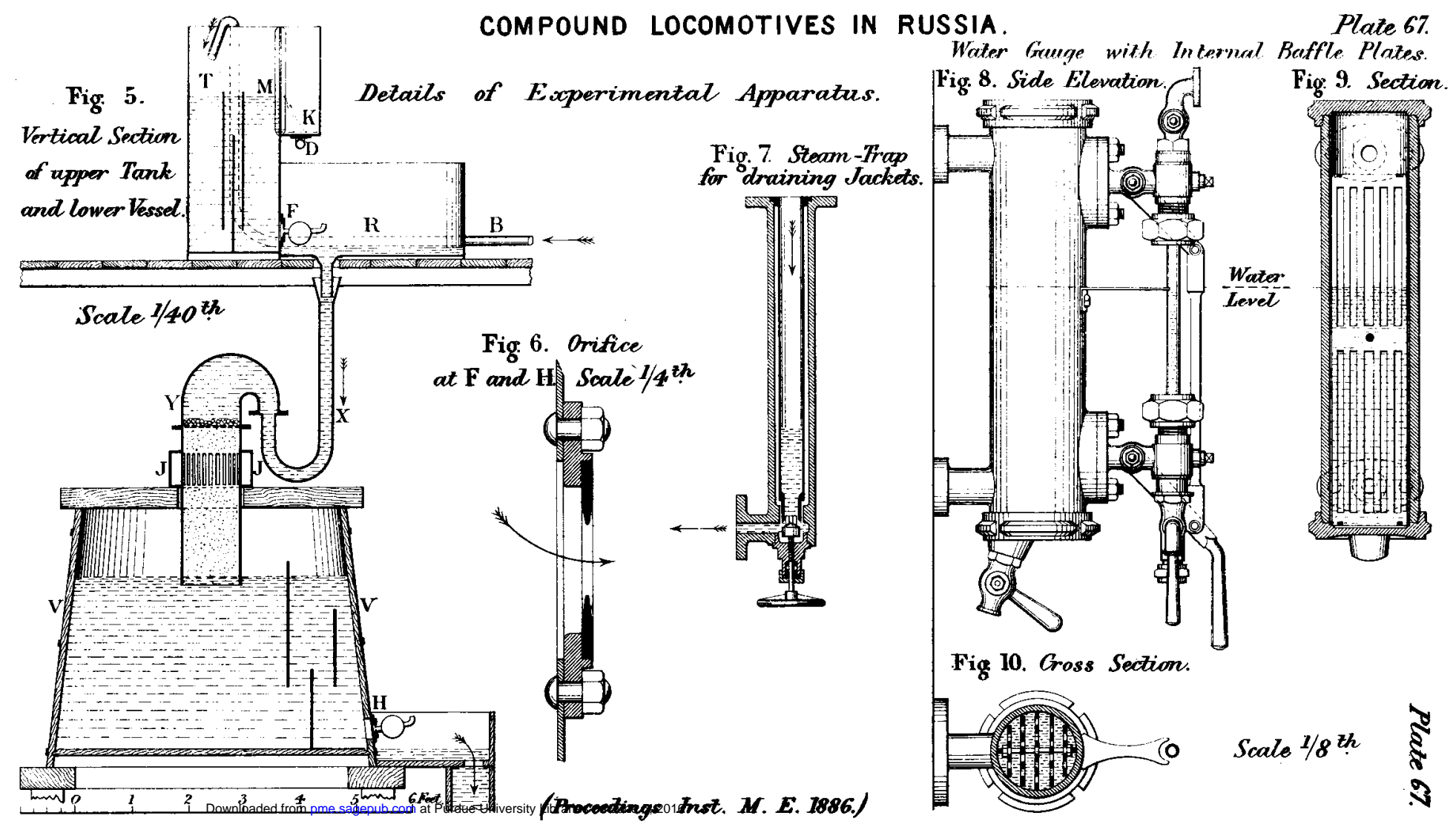




\section{COMPOUND LOCOMOTIVES IN RUSSIA. Plaze 68.}

\section{Indicator. Diagrams from ORDINARY Locomotive A22.}

Jackets working. Jackets NOT working----

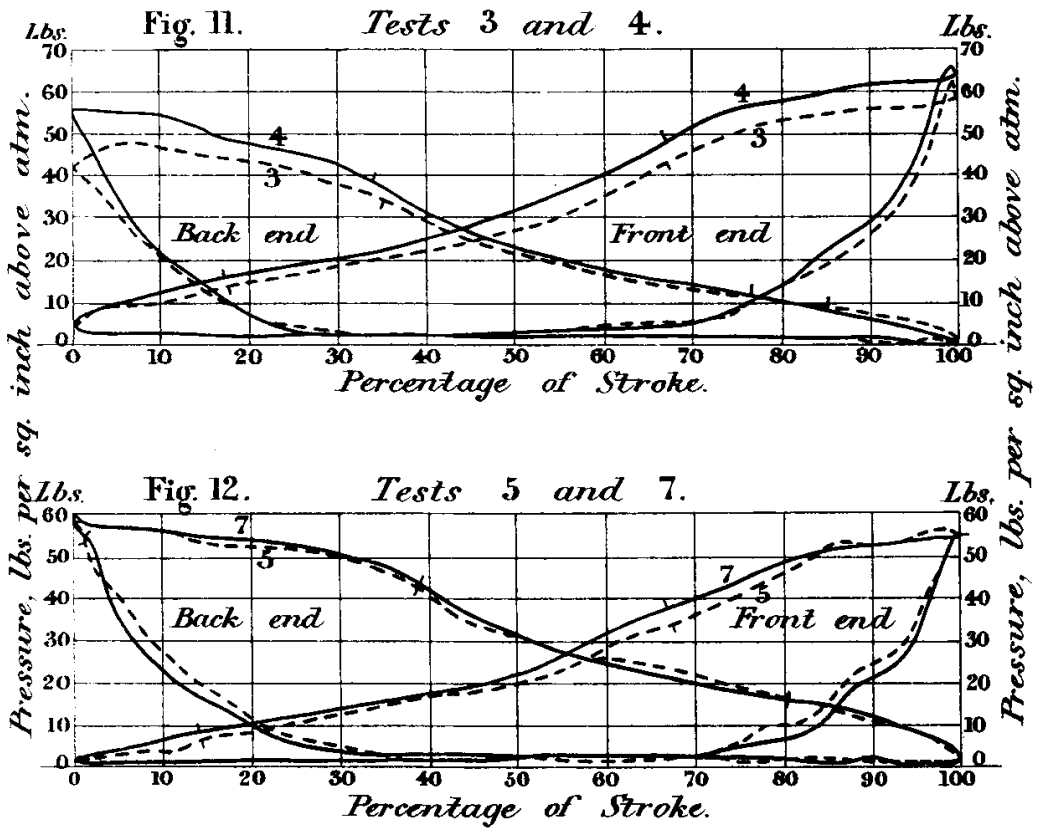

Lbs. Fig. 13. Test 8

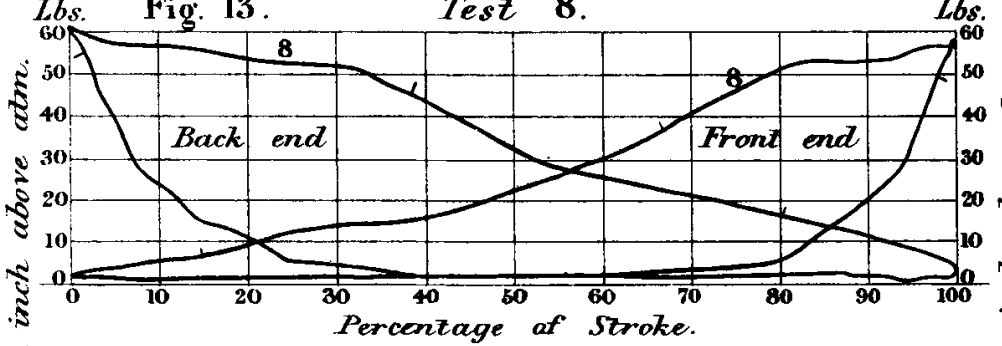

si

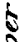

RLb. Fig. 14. Tests 10 and 11 .

Lbs.

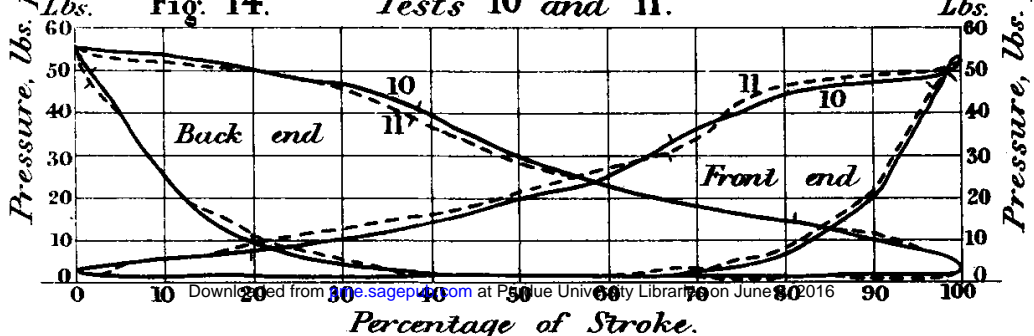

(Proceedings Inst. M. E. 1886.) 
Indicator Diagrams from ORDINARY Locomotive A 22. Jackets working. Jackets NOT working----

Lbs. Fig. 15. Tests 13 and $15 . \quad$ Lbs.

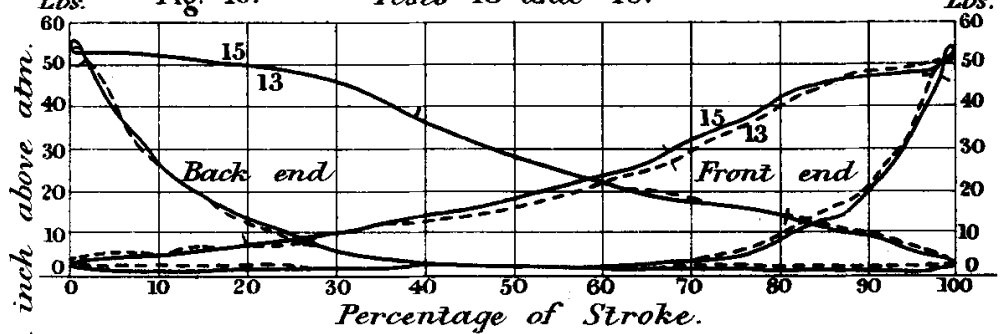

sit

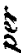

Lbs. Fig. $16 . \quad$ Tests 17 and 26

Las.

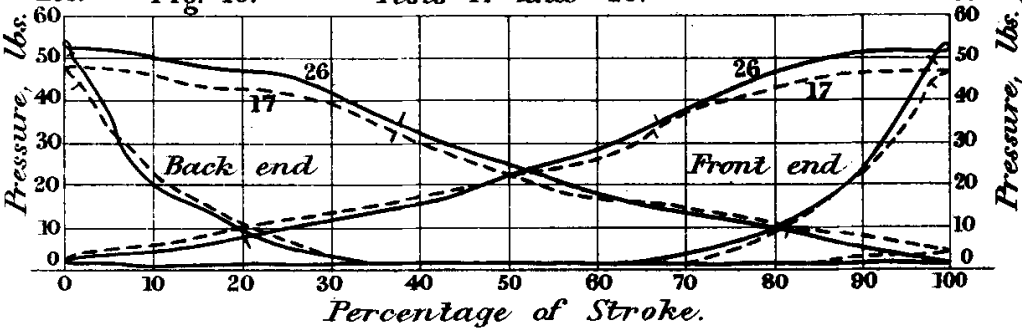

Lhs. Fig: 17 .

Test. 25.

Lbs.

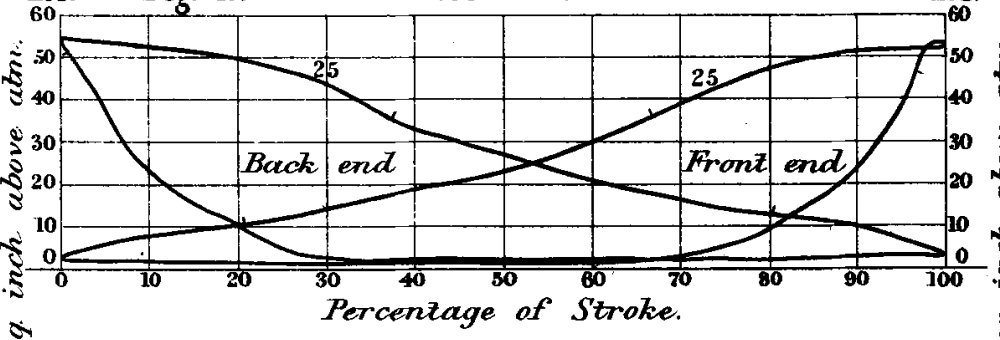

sit

s.

Lbs. Fig. 18 Tests 23 and 28.

600 - The 18 .

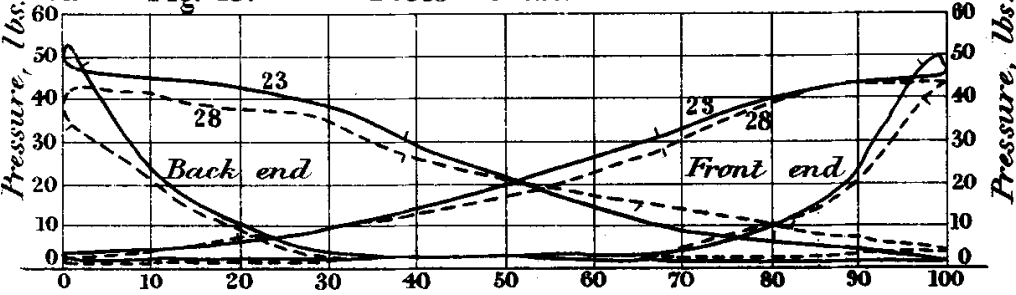

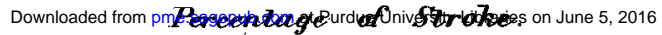

(Aroceedings hust M. E. 1886.) 


\section{COMPOUND LOCOMOTIVES IN RUSSIA. Plate 70.}

Indicutor Diagrams from ORDINARY Locomotive A 22.

- Sackets working. Jackets NOT working----

Lbs. Fig. 19. Tests 29 and 33.

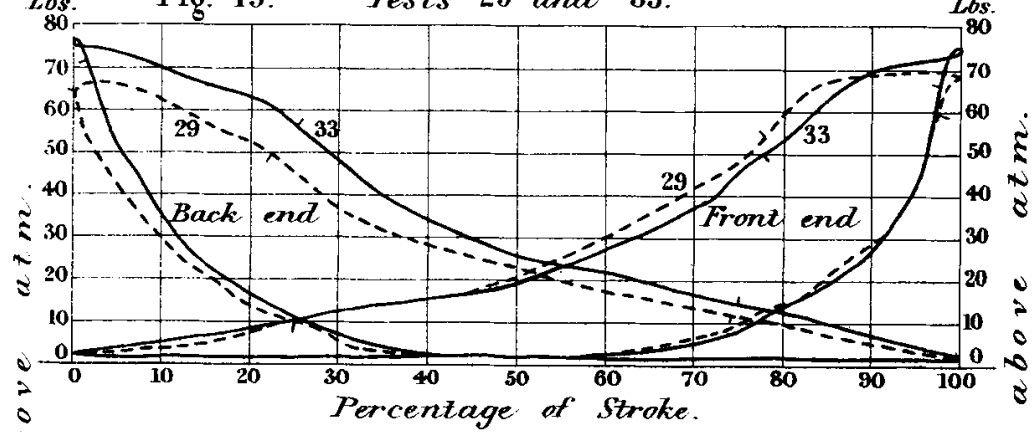

LLbs. Fig. $20 . \quad$ Test 32 .

Lbs.

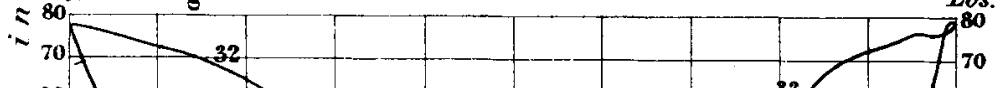

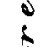

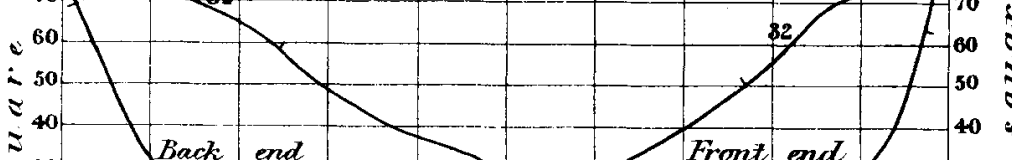

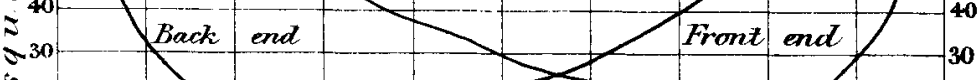
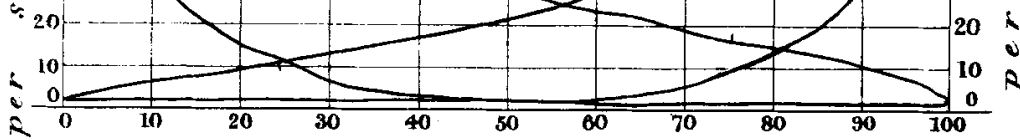

$\ddot{0}$

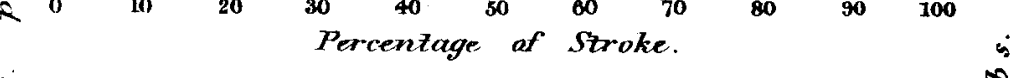

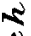

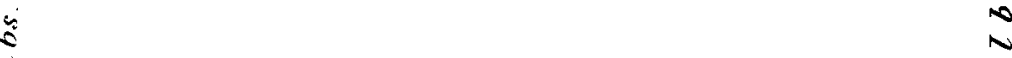

ilbs. Fig. 21. Tests 31 and 34 Lbs.

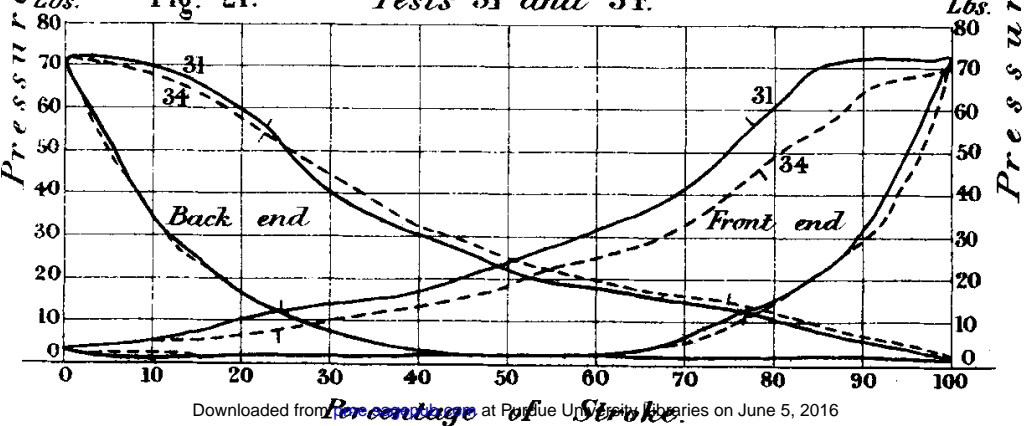


COMPOUND LOCOMOTIVES IN RUSSIA. Plate 71.

Indicator Diagrams from ORDINARY Locomotive A 21.

\section{Jackets NOT working.}

Lbs. Fig. 22. Boiler Pressure 80 Zbs. above atm. Lbs.

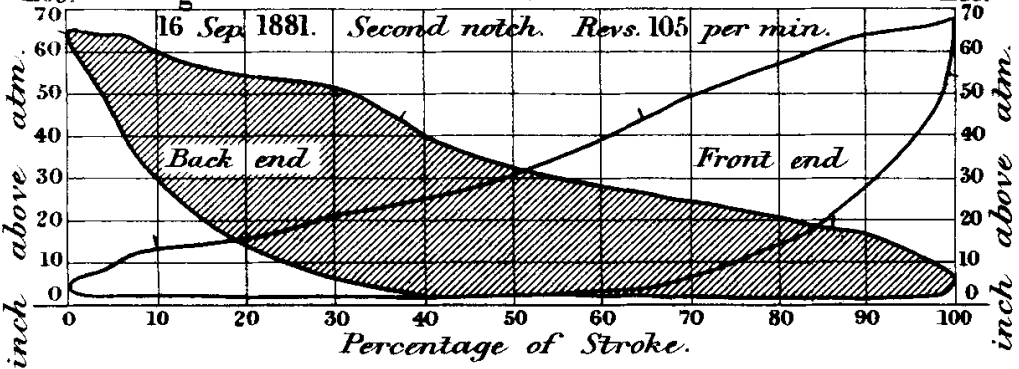

Sibs. Fig. 23. Boiler Pressure 91 lbs. abave atm. Lbs. के

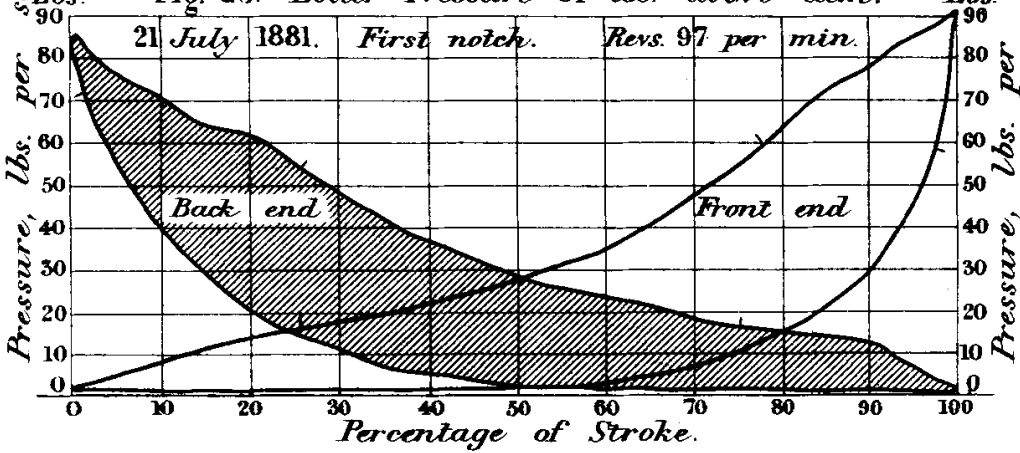

Indicator Diagrams from COMPOUND Locomotive A 7 .

Jackets NOT working.

Lbs. Fig. 24. Boiler Pressure 99 lbs. above atm. Lbs.
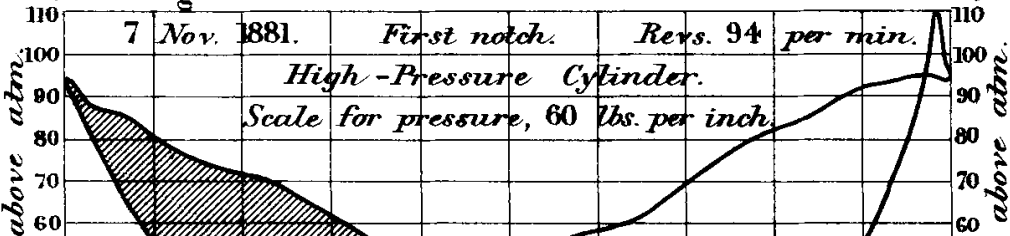

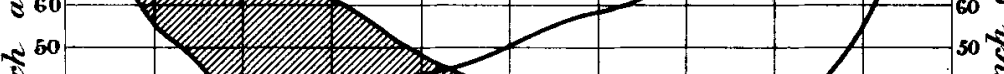
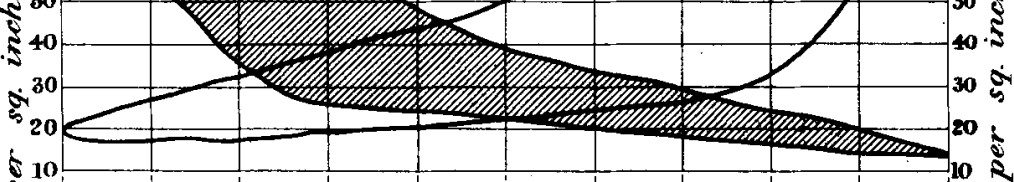

R

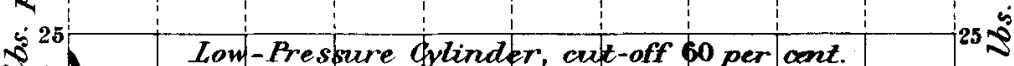

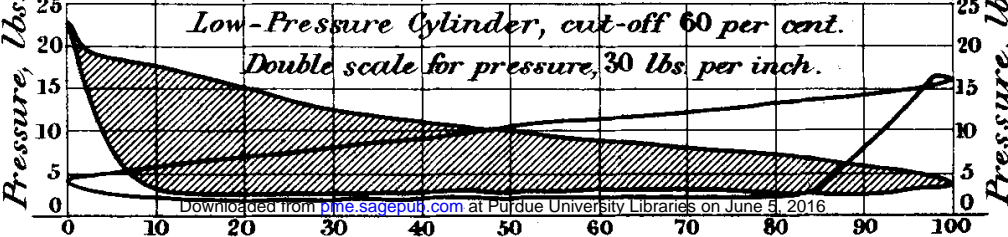

(Procedings Fist. M.E.1886) Parcentage of Stroke. 
COMPOUND Locomotive A 7, High-Pressure Cylinder.

Mean Forward Pressure in Percentage of Boiler Pressure. per cent Fig. 25. Front end. per cent

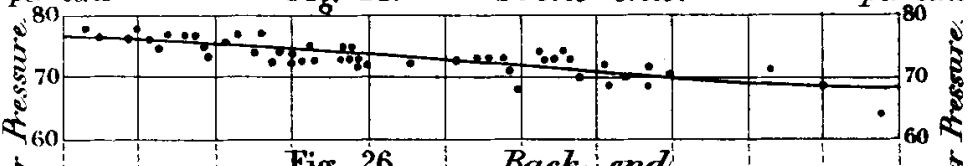

$\$ 0$ Fig 26. Back end

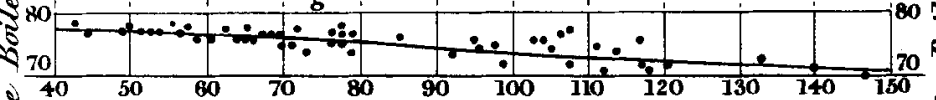

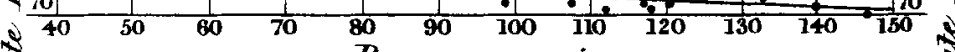

Mean Back-Pressure in Percentage of Boiler Pressure. Sper cent Fig. 27. Front end. per cent

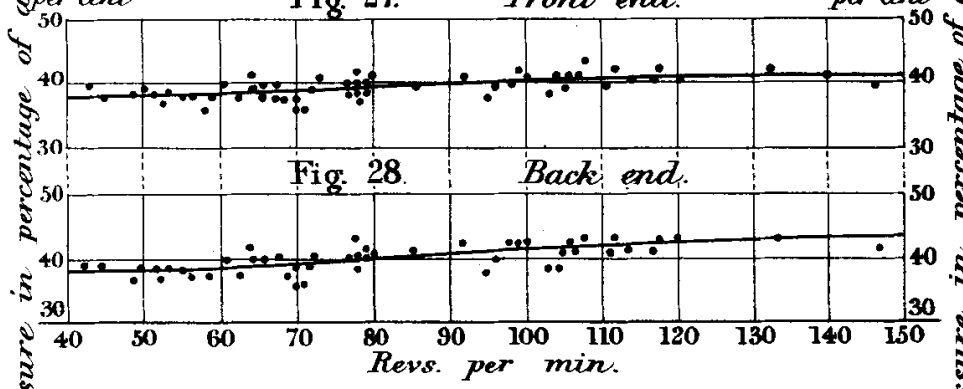

COMPOUND Locomotive A7, Low-Aressure Cylinder.

S Mean Forward Pressure in Percentage of Boiler Pressure.

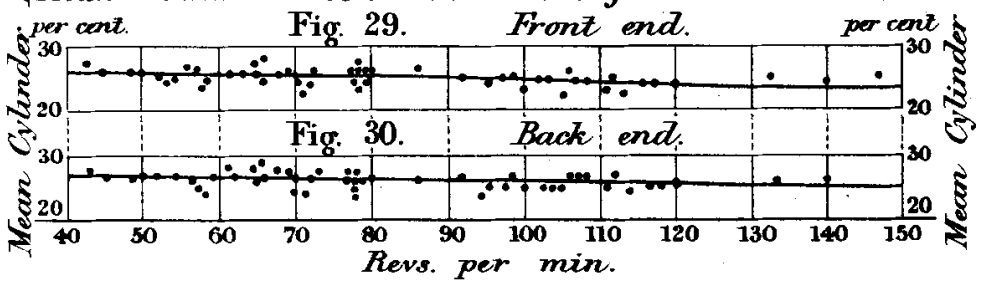

Mean Back-Pressure in Zbs. per square inch above atm.

Lbs. Fig. 31. Front and.

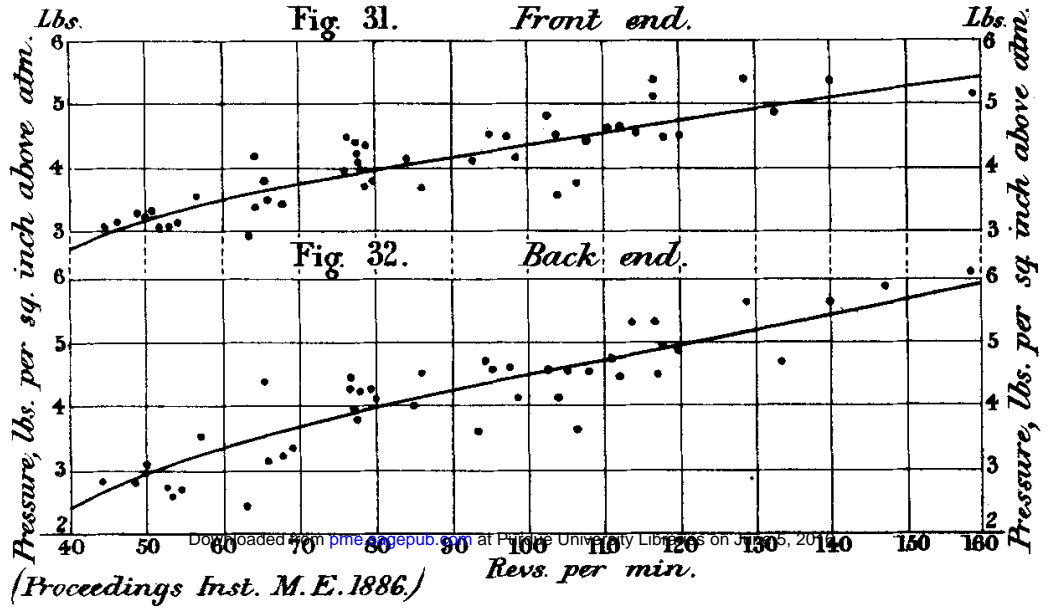




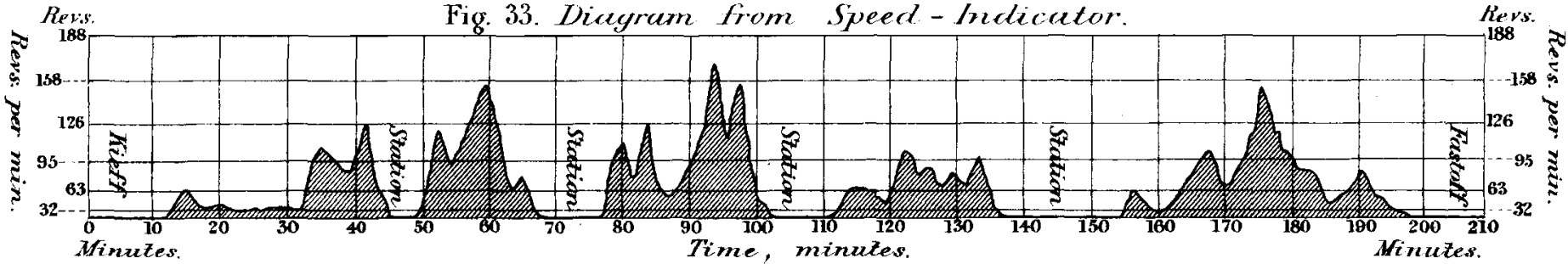

Lbs. Fig. 34. Consumption of Water per 1.H.P. per hour according to degree of Exponsion Lbs.

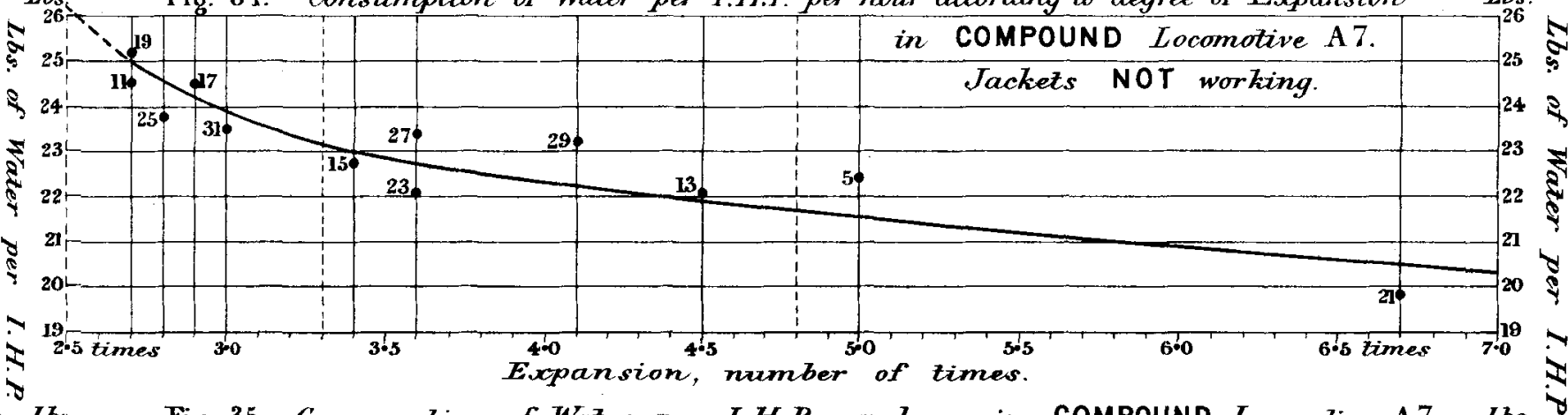

Lbs. Fig. 35. Consumption of Water per I.H.P. per hour in COMPOUND Locomotive A7. Lbs. Tे

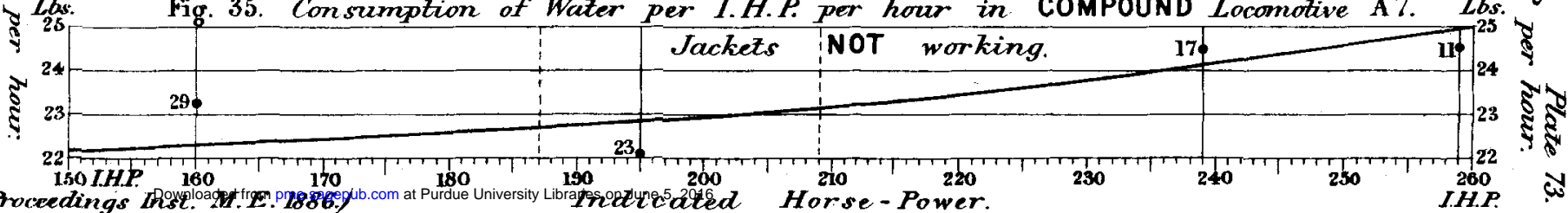


Irelicator Diagrams from ORDINARY Locomotive A 22.

\section{Jackets NOT working.}

Fig. 36. Boiler Pressure 127 lbs above atm. Revs. 75 per min.

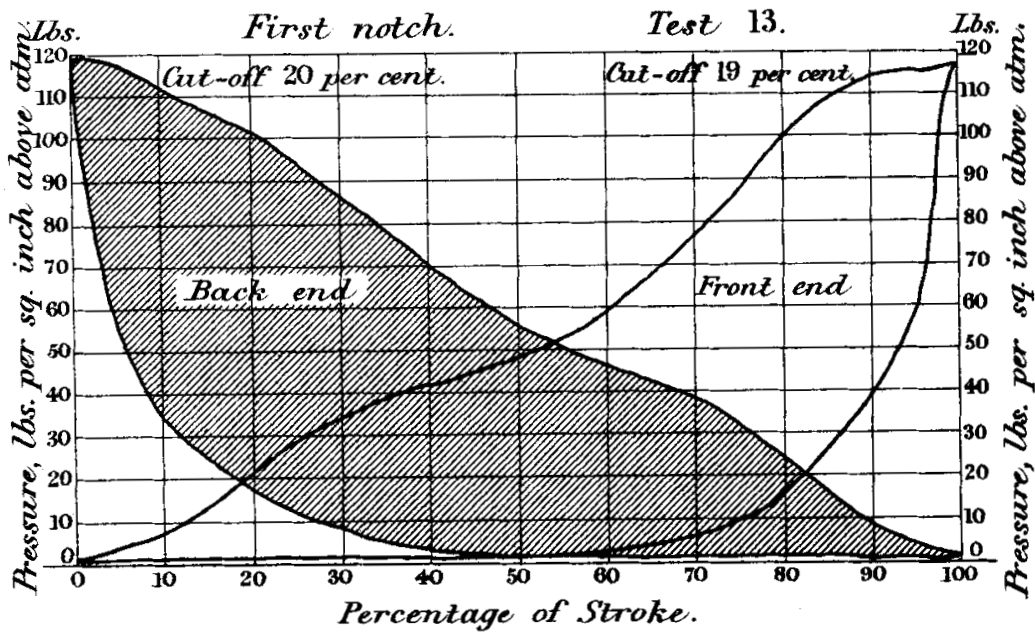

Fig. 37. Boiler Rressure 126 lbs. above atm. Revs. 90 per min.

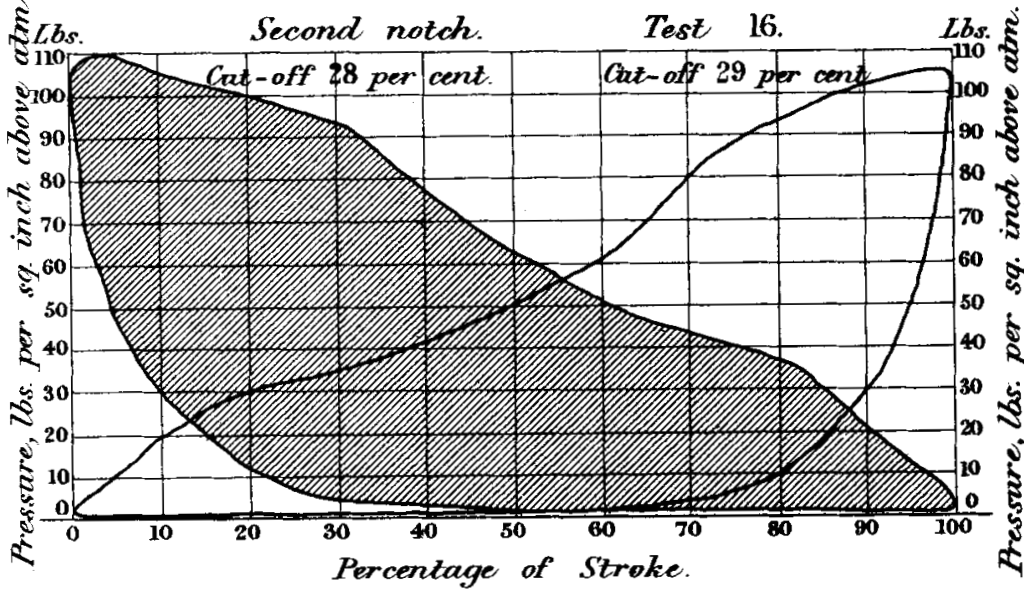


Indicator Diagrams from ORDINARY Locomotive A 22.

Jackets NOT working.

Fig. 38. Boiler Pressure 127 lbs above atm. Revs. 80 per min.

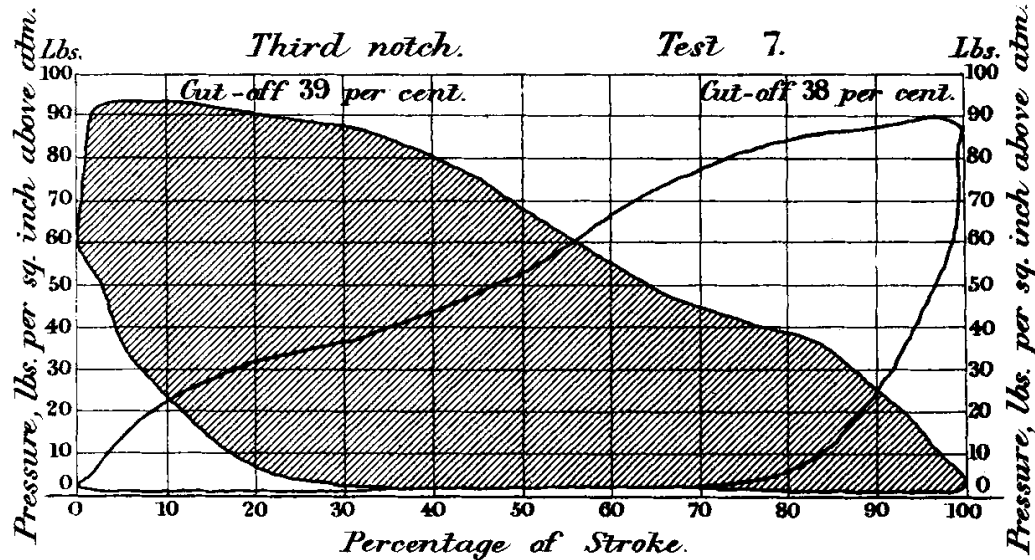

Fig. 39. Boiler Pressure $130 \mathrm{lbs}$. above atm. Revs. 61 per min.

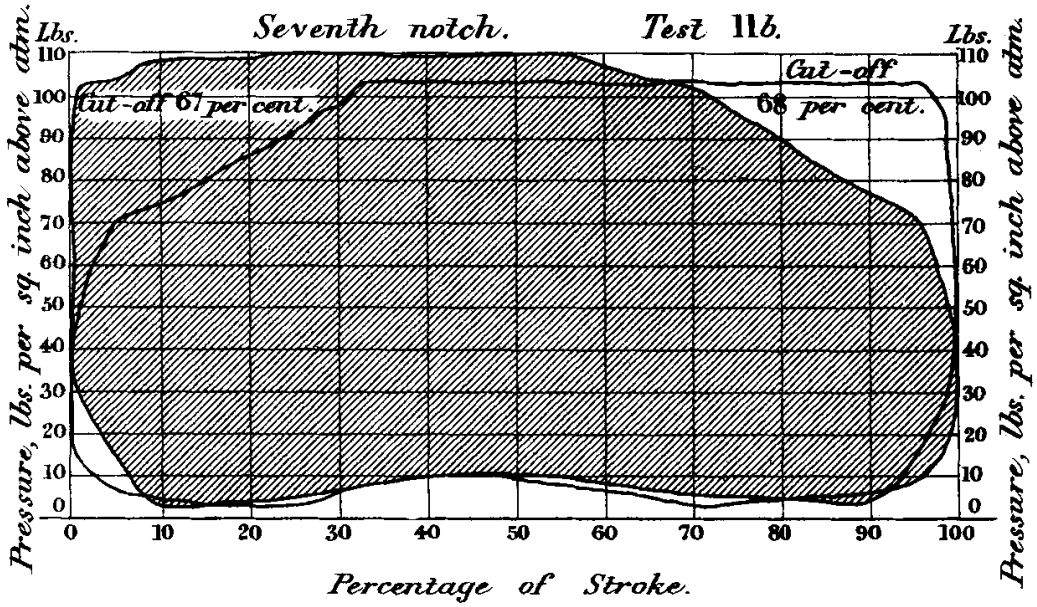


Lbs. COMPOUND LOCOMOTIVES IN RUSSIA. Plaze 76.

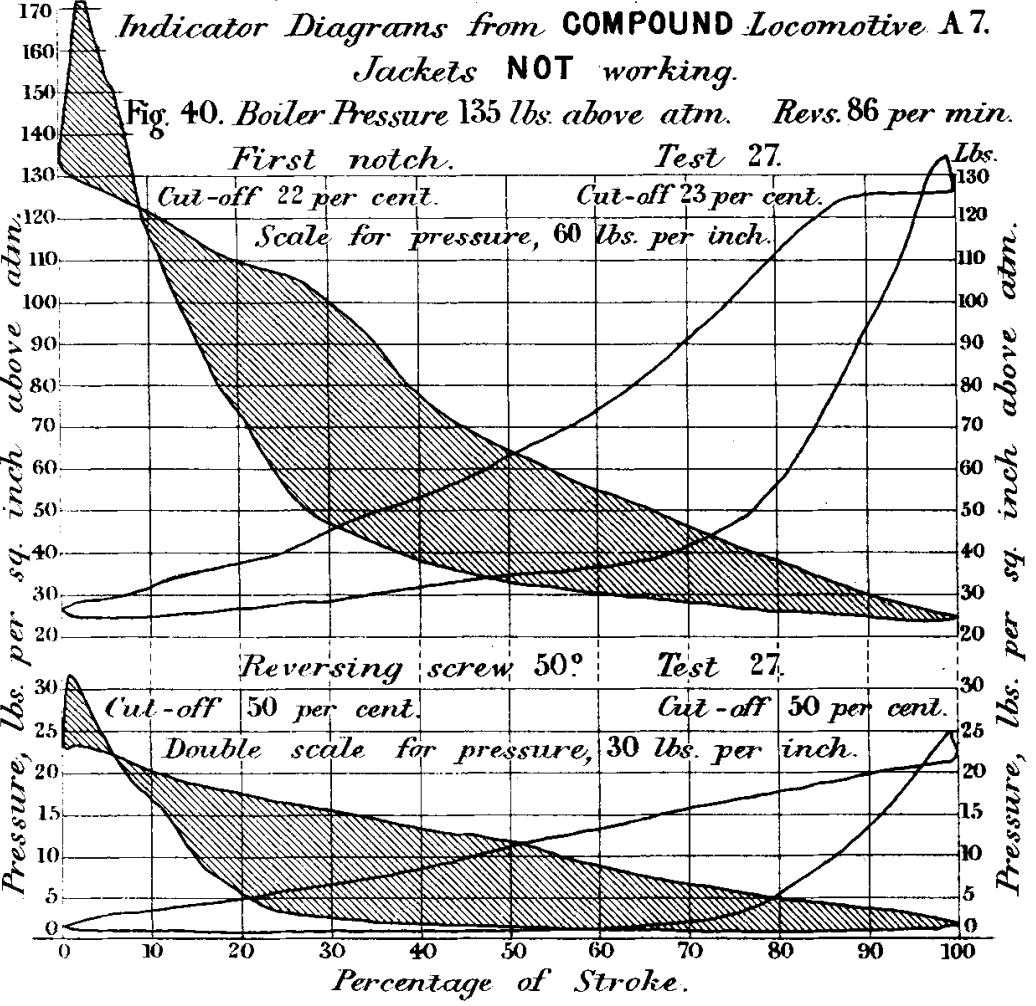

Fig. 41. Boiler Pressure 120 lbs. above atm. Revs. 83 per min. Lbs. First notch. Test $21 . \quad$ Lbs.

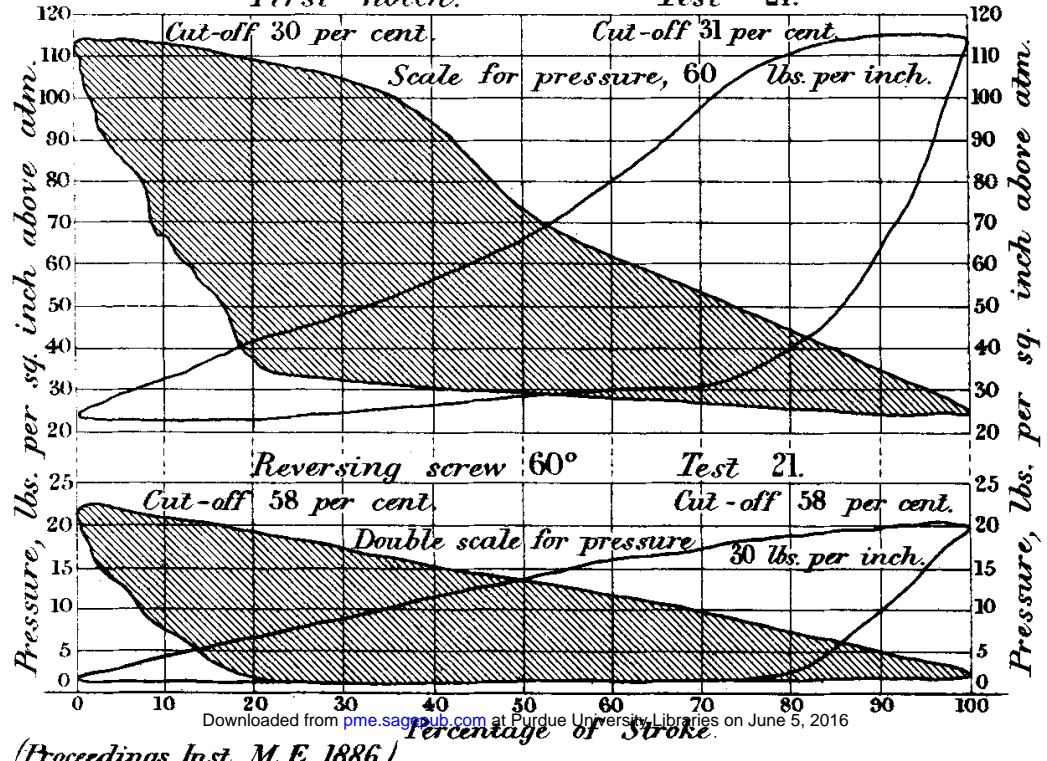

(Hoceedings list. M.E. 1886.) 
COMPOUND LOCOMOTIVES IN RUSSIA. Plate 77. Indicator Diagrams from COMPOUND Locomotive A 7 . Jackets NOT working.

Fig. 42 Boiler Pressure 138 lbs. above atm. Revs. 89 per min.

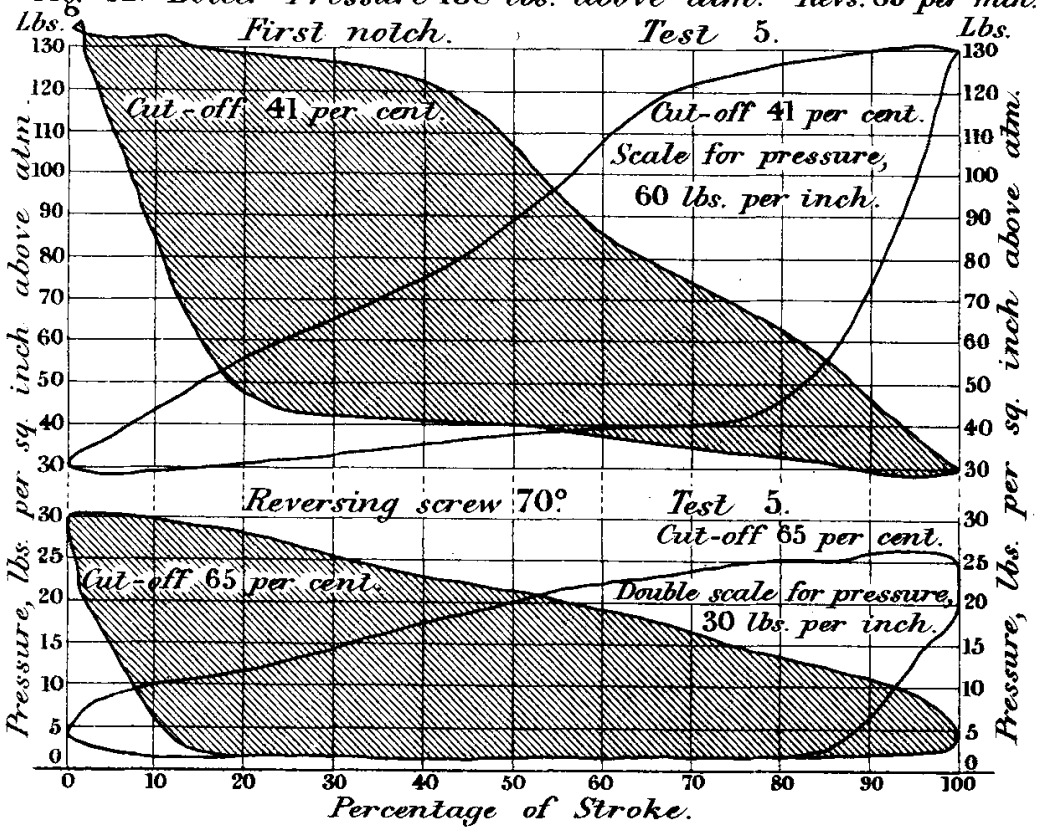

Fig. 43. Boiler Pressure 140 lbs. above atm. Revs. 65 per min.

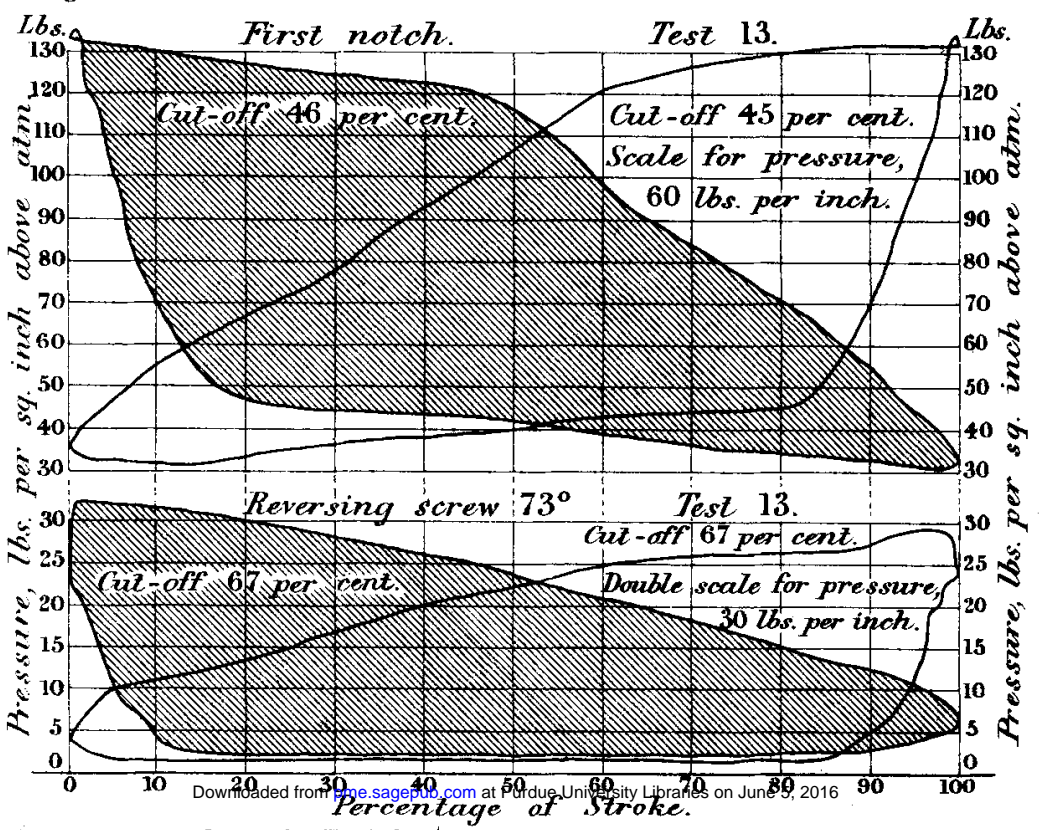

(Proceedings Inst. M. E. 1886.) 
COMPOUND LOCOMOTIVES IN RUSSIA. Plate 78. Indicator Diagrams from COMPOUND Locomotive A 7. Fiog 44. Seventh notch. Briler. Pressure 131 ibs. above atm. Test 31


Lbs. Fio. 45. Seventh notch Boiler P. essure 135 ibs.above atm. Test 25. Lbs.

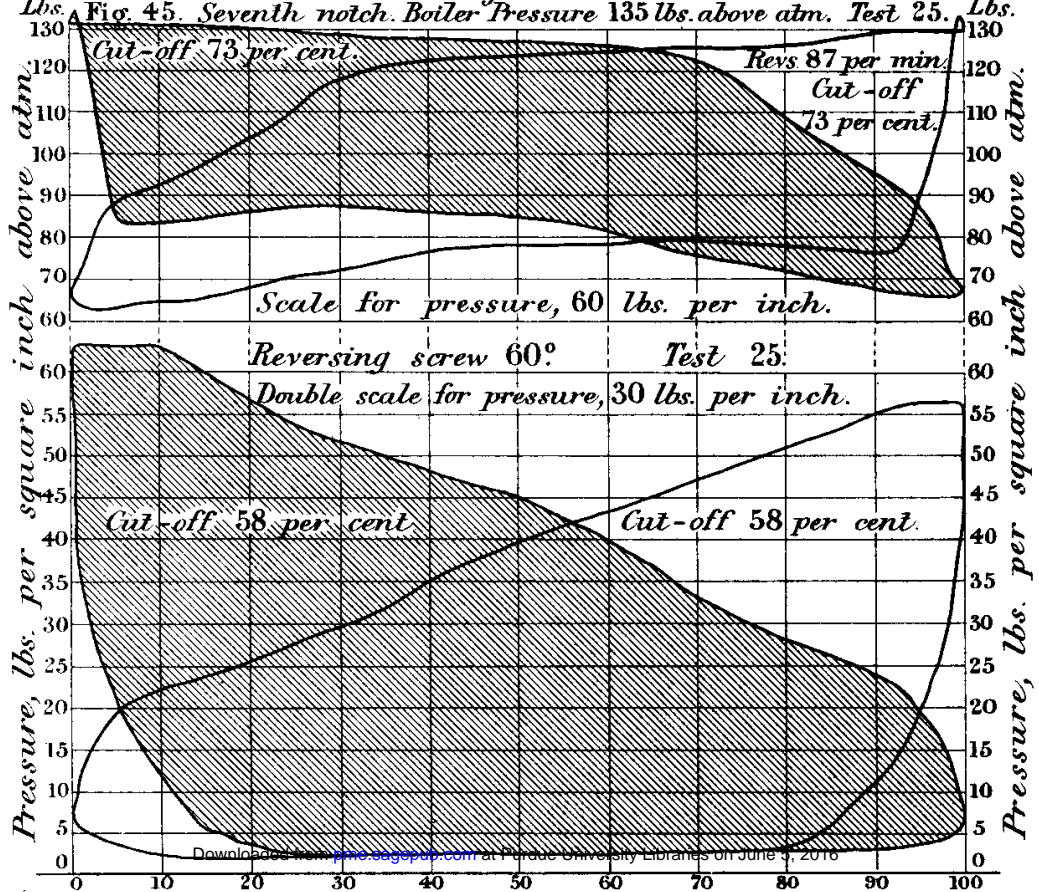

(B-oceedings Inst. M. E. J886) Percentage of Stroke. 
COMPOUND LOCOMOTIVES IN RUSSIA. Plate 79.

Indicator Diagrams from COMPOUND Locomotive A 7.

\section{Jackets NOT working.}

Lbs. Fig. 46. Seventh notch. Boiler Pressure 114 lbs. above atm. Test 11 .Lbs.

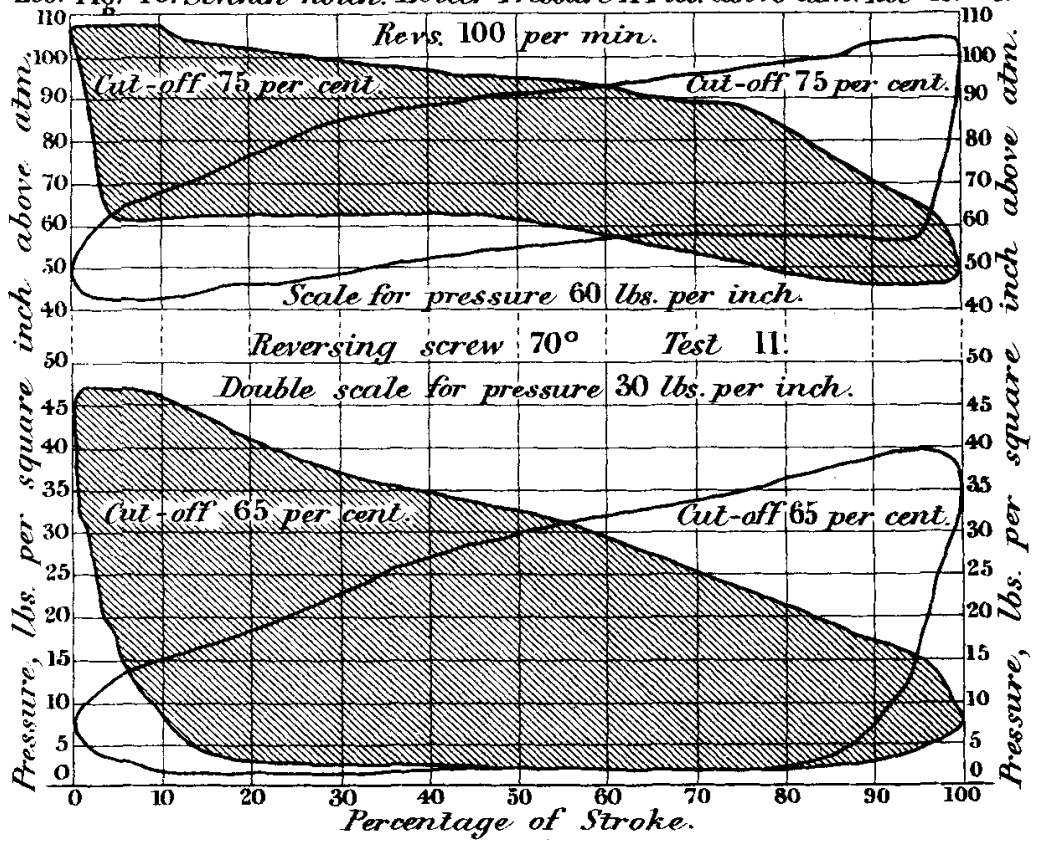

Lbs. Fig. 47. Seventh notch. Boiler. Aressure 123 lbs. above atm. Test 19. Lbs.
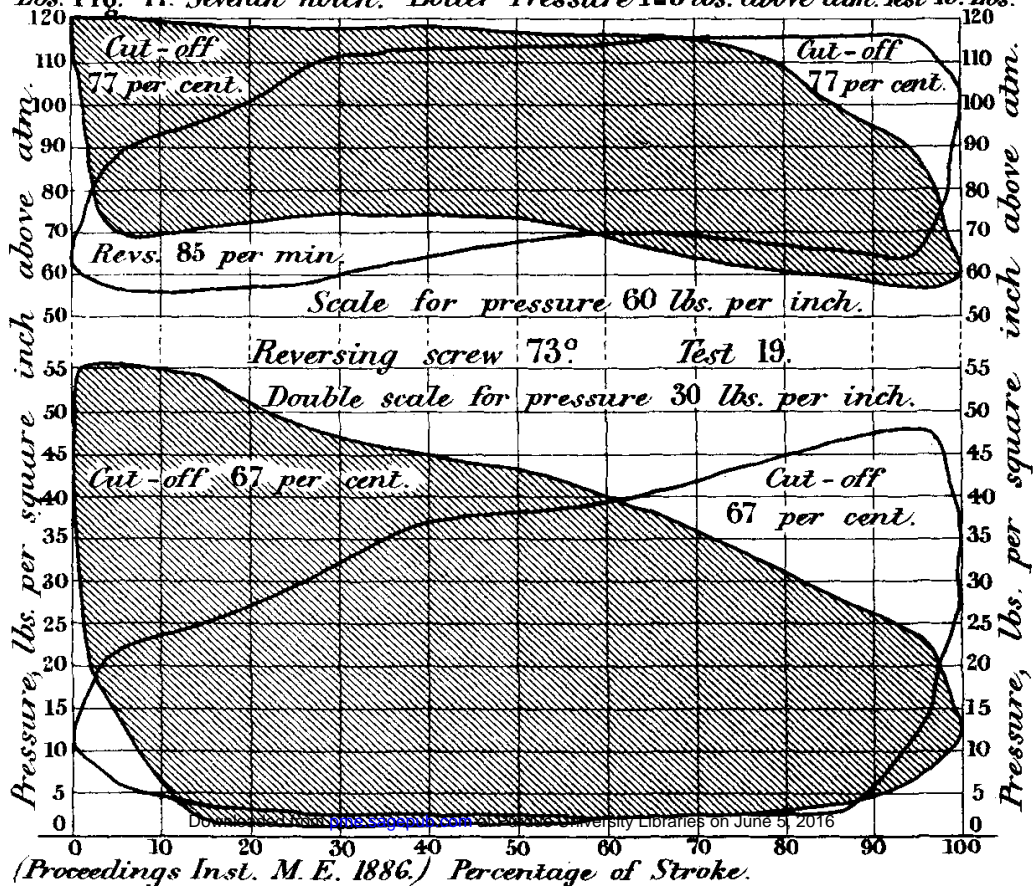

(Proceedings Inst. M. E. 1886.) Percentage of Stroke. 